\title{
Kerkenes Kazısı 2012-2013 Yılları Çalışmaları ve Yerleşimin Tanımlanması Üzerine Değerlendirmeler
}

\author{
The 2012-2013 Excavations at Kerkenes and Evaluations \\ of the Settlement
}

\begin{abstract}
Abdulkadir BARAN*
Öz: Yozgat İli, Sorgun İlçe'si yakınında yer alan Kerkenes yerleşimi iyi belgelenmiş bir yerleşim olarak bilinmesine karşın kazıların sınırlı olmasına bağlı olarak yerleşimle ilgili hemen her bilgi halen tartışılabilir durumdadır. 2012-2013 yıllarında ekibimiz yerleşimde çalışma firsatı edinmiştir. Hem çalışmalarımızın sonuçları hem de yerleşimle ilgili değerlendirmelerimiz bu makalenin kapsamını oluşturmaktadır. Dönemine göre Anadolu'daki en büyük boyutlu yerleşim olan Kerkenes'in stratejik konumu, tahkimat sistemi ve yerleşim sistemi yerleşimin askeri karakterine işaret etmektedir. Bu nedenle, Kerkenes’in Lydia krallığı tarafından Samsun Akalan ve Niğde Göllüdağ ile birlikte kurulan üç askeri garnizondan biri olduğu önerilmektedir. Lydia Krallığın genişleme evresinde özellikle Kimmerlere karşı yürütülen savaşta güçlü bir ön hat oluşturmak için tahkim edilmiş bu yerleşimler Medlerle yapılan antlaşma sonrasında Pers savaşlarına değin ağırlıklı olarak ticari aktiviteler için bir sınır yerleşimi olarak kullanılmış olmalıdır. Yerleşimi tamamen kaplayan yapıların yoğunluğu ve görülen farklılıklar ile yoğunlukla Phryg kültürüne işaret eden buluntuların varlığı Lydia ordusunun egemenliği altındaki halklardan oluşturulmuş olmasıdır. Lydia Krallığı'nın yıkılmasından sonra bölge halkı için oldukça büyük boyutlu olan bu yerleşim Pers İmparatorluğu için de kullanışsız hale geldiği için bir daha iskan edilmemiştir. Herodotos tarafından Pteria (kanat, sınır hattı ?) olarak adlandırılan bölgede yer alan yerleşim bir Lydia askeri garnizonu olduğu için normalde sivil halkın yaşamadığı ve ismi bulunmayan bir yerleşim olmalıdır. Bu durum da yerleşimin antik yazarlar tarafından bilinmemesinin ve diğer yazılı metinlerde bahsedilmeyişinin gerekçesi olarak anlaşılabilir.
\end{abstract}

Anahtar sözcükler: Kerkenes, Pteria, Demir Çağ, Lydia, Phrygia

Abstract: The site on Kerkenes Mountain near Sorgun, Yozgat is supposedly a well-documented site, but almost anything about the site is still discussable, because of insufficient excavations. Our team had the opportunity to work in 2012 and 2013 on the site and the results of our works and some suggestions about the site's history and function are the topics of this paper. We could excavate $100 \mathrm{~m}$ long part of fortification wall and part of a building block. The results of the excavations and site arrangements made the site more accessible and understandable. Kerkenes was the biggest and crowded site for its period in Anatolia and the strategic position of site together with the fortification and occupation arrangements is best explained with the military character of the site. Therefore, it seems suggestible that Kerkenes was a military foundation of Lydian Kingdom together with Akalan in Samsun and Göllüdağ in Niğde. It served as a stronghold for the Lydian Army during their expansion period and especially wars against Cimmerians in the VII ${ }^{\text {th }}$ century and after the peace with Medes functioned as a border site functioned mainly for commercial activities together with Akalan and Göllüdağ till Persian wars. The differences in the building designs which cover almost all the enclosed area and the finds from different cultures, which are mostly Phrygian, were because the Lydian army was combined by all the nations under Lydian rule. After the fall of Lydia this destroyed site which was too big for any local community in the region and useless for Persian Empire, was not occupied again. Because, the site was actually a Lydian garrison in the region called as Pteria (wing, border line?) by Herotodus should never had a civil population and a name. This must be the reason for being unknown to the ancient writers and not being mentioned in any documents or inscriptions in the history.

Keywords: Kerkenes, Pteria, Iron Age, Lydia, Phrygia

* Doç. Dr., Muğla Sttkı Koçman Üniversitesi, Edebiyat Fakültesi, Arkeoloji Bölümü, Muğla. baran@mu.edu.tr 
Yozgat İli'nin Sorgun İlçesi'ne bağlı Şahmuratlı Köyü'nün batısındaki Kerkenes Dağı'nda yer alan ve antik adı henüz net olarak bilinmediği için Kerkenes olarak anılan yerleşim (Fig. 1), daha önce yürütülen çalışmaların sonuçlarına göre MÖ VII. yüzyıl sonlarında kurulmuş ve MÖ 546 y1lında Lydia Kralı Kroisos ile Pers Kralı Kyros arasındaki savaş sonrasında terk edilerek kısmen tahrip edilmiştir (Summers 2013a, 137 vd.). İlk çalışmalar sonrasında bir Med kenti olduğu önerilen yerleşimin daha sonradan ele geçen buluntular sayesinde büyük olasılıkla Phryg kültürüne sahip batıdan göç etmiş bir topluluk tarafindan Pteria krallığının merkezi olarak kurulmuş olduğu önerilmiştir. Yerleşimin adına ilişkin kesin bir veri olmamakla birlikte Herodotos (I. 76) tarafindan bahsedilen Pteria olduğu büyük oranda kabul edilmektedir. Kerkenes’te yürütülen araştırmalar terk edildikten sonra bir daha tam anlamılla yerleşim görmemiş olduğunu, sadece Helenistik dönem sonrasinda güneydeki Kiremitlik mevkiinde ve Keykavus Kale olarak adlandırılan tepedeki kalede

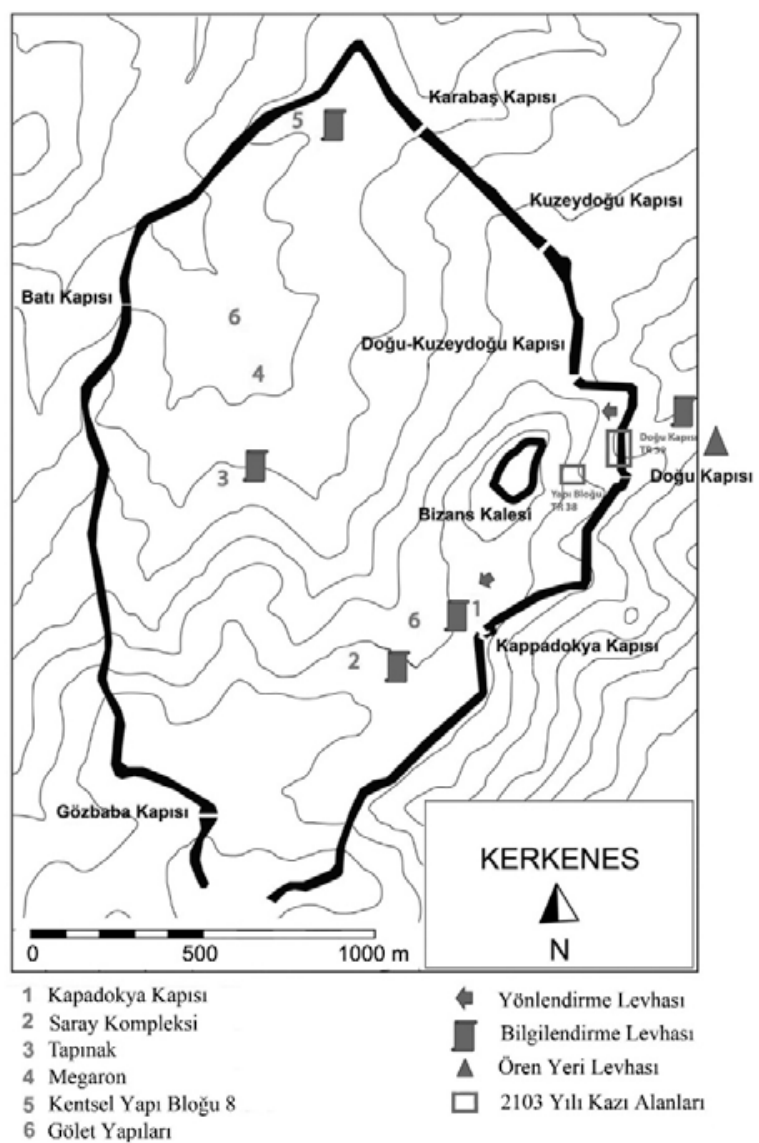

Fig. 1. Kerkenes Yerleşim Planı

küçük alanlarda kısmi yerleşimler bulunduğunu ve çok sayıda geç dönem mezarının kalıntılar üzerine inşa edilmiş olduğunu göstermiştir. Bizans döneminde de Kalenin stratejik konumu sebebiyle yeniden kullanılmış olduğu önerilmektedir. Anadolu'da Klasik Dönem öncesine ait en büyük boyuta sahip olan yerleşim $7 \mathrm{~km}$ uzunluğa sahip sur duvarlarıyla çevrelenmiştir ve en geniş yerinde 1,5 x 2,5 km ölçülere ulaşmaktadır. Jeofizik araştırmalar sonucunda birbirilerinden cadde ve sokaklarla ayrılmış farklı ölçülerde 757 adet yapı bloğunun yerleşimi tamamen kapladığ 1 tespit edilmiştir.

1993 yılından itibaren devam eden kazı çalışmalarında yaşanan bazı sıkıntılar sebebiyle 2012 ve 2013 yıllarında kazı çalışmalarının bilimsel danışmanlığı ekibimize verilmiş̧ir. Bu yayında öncelikle ekibimiz tarafından gerçekleştirilen kapsamlı çalışmalar hakkında bilgi verilecek ve sonrasında arkeolojik açıdan hala tam çözülmemiş olan konular hakkında değerlendirmeler yapilacaktır.

\section{Kazı ve Çevre Düzenleme Çalışmaları}

Yozgat Müzesi başkanlığında yürütülen 2012 ve 2013 kazılarında öncelikli amacımız ivedilik gerektiren ve eksik görülen alanların tespit edilerek çözümler getirilmesi olmuştur (Kazı raporları için bk. Baran 2014; 2015). Bu bağlamda 2012 yılı Kerkenes Kazı Çalışmalarına 14.08.2012 tarihinde başlanılmış ve 14.10.2012 tarihinde tamamlanmıştır. İki dönem halinde 22.08.2012 - 05.09.2012 tarihleri arasında 15 gün ve 15.09.2012-13.10.2012 tarihleri arasında 29 gün süresince gerçekleştirilmiş olan kazı çalışmalarının ilk döneminde Chicago Üniversitesi ekibinin yürüttüğü Yapı Bloğu 8 kazılarına yoğunluk verilmiştir. İkinci evre çalışmalarımız ise 
Doğu Kapı yakınında sur duvarı ve çevresinde gerçekleştirilmiştir. 2013 yılı Kerkenes kazı çalışmaları ise tamamen Muğla Sitkı Koçman Üniversitesi ekibi tarafından yürütülmüştür. Doğu Kap1 yakınındaki sur duvarı ve hemen batısındaki bir yapı bloğunda yürütülen kazı çalışmalarına 23.08.2013 tarihinde başlanılmış ve 21.09.2013 tarihleri arasında sadece 29 gün çalışabilerek tamamlanmıştır. Oldukça yoğun ve istekli çalışmamıza rağmen müze ile yaşanan sıkıntıların artarak devam etmesi ve giderilmesi yönünde de bir umut olmaması sebepleriyle 2014 yılı itibarıyla çalışmama kararı alınmış ve 2014 itibarıyla kazı çalışmaları ilk yıllarından itibaren Kerkenes kazılarında görev almış olan Doç. Dr. Scott Branting ve ekibi tarafindan yürütülmeye başlanmıştır.

1993 yılından itibaren kesintisiz çalışmalar yürütülmesine karşın yeterli kazı ve restorasyon çalışmasının yapılmamış olmasının yanı sıra ulaşım, bilgilendirme ve koruma anlamında da temel sıkıntıların giderilmediği ve Kerkenes'e ulaşmak isteyenlerin yakınına kadar gelebilseler bile kalıntıların nerede olduğunu anlamadan geri döndükleri görülmüştür. Bu nedenle en acil sorun olarak yerleşimin ulaşılabilirliği konusu tespit edilmiştir. Sorgun ilçesi içerisinde eskimiş ve zorlukla okunabilen sadece bir adet tabela bulunduğu, pek çok dönüş olan $14 \mathrm{~km}$ uzunluğundaki Kerkenes'e ulaşan yolda ise sadece bir adet delik deşik olmuş Kerkenes tabelası yer alması ulaşım açısından en temel sıkıntı olarak tanımlanmıştır. Bu konuda yerel idarenin girişim yapması için çaba gösterilmesine karşın herhangi bir gelişme olmaması üzerine kazı ekibi olarak gerekli düzenlemeler yapılmıştır. Bu kapsamda bozulmuş olan tabelalar yenilenmiş ve yeni tabelalar eksik olan dönüşlere yerleştirilerek ziyaretçilerin Sorgun'dan itibaren daha kolay ve sıkıntı çekmeden ulaşımları için gerekli tedbirler alınmıştır. Her ne kadar kent surunun Doğu Kapısı yakınındaki kısma kadar arabayla ulaşılsa da ziyaretçilerden gözü alışık olmayanların kente geldiklerini fark etmedikleri, fark edenlerin ise kent içinde yönlerini bulamamaları düzeltilmesi gereken bir diğer sorun olarak görülmüştür. Ziyaret edilebilir durumdaki kalıntıların az sayıda olmasına karşın insanların kenti rahatça gezebilmeleri için Genel Müdürlüğümüzün kabul ettiği standartlarda bilgilendirme ve yönlendirme tabelaları hazırlatılarak yerlerine yerleştirilmiştir. Kente arabayla ulaşılan Doğu Kapı yakınındaki alana ören yeri tabelası ve genel bir bilgilendirme levhası ile Saray Kompleksine ulaşan toprak yol boyunca kavşak noktalarına mesafeleri ve yönleri gösteren yeterli sayıda yönlendirme levhası yerleştirilmiştir. Kısmen görülebilir durumdaki Kapadokya Kapısı, Saray Kompleksi, Tapınak ve Yapı Bloğu 8 alanlarına da eski çalışmaların sonuçlarına uygun bilgiler içeren Bilgilendirme Levhaları dikilmiştir. Tüm bu çalışmalar sonucunda kenti gezmeye gelen ziyaretçilerin arazide kaybolmadan birbirinden oldukça uzak olan bu kalıntılara ulaşabilmeleri ve bilgi edinmeleri sağlanabilmiştir.

Yerleşimde bekçi olmayışı ve tek bekçinin kazı evinde bulunması sebebiyle Şahmuratlı Köyü içerisinde Kerkenes'e ulaşan yolun hemen kenarında yer alan Kazı Evinde de düzenlemeler yapılarak kente ulaşmak isteyen insanların durarak bekçiden bilgi ve broşür edinmeleri amaçlanmıştır. Bu bağlamda sadece Türk Bayrağı bulunmasıyla farklılık gösteren evin önüne Kazı Evi tabelası ve Kerkenes ile ilgili bir bilgilendirme Levhası yerleştirilmiştir. Kazı Evini ve depoları içeren alanda güvenlik zafiyeti gösteren detaylar hakkında Müze Müdürlüğüne bilgi verilmiş, bazı kısımlarında da tel örgülerle güçlendirmek gibi düzenlemeler gerçekleştirilmiştir.

Arazi çalışmalarımızın ilk aşaması ise daha önceden kısmen kazısı yapılmış alanlarda acil müdahale gerektiren unsurların tespit edilerek, gerekli düzenlemeler yapılması olmuştur. Sadece ön giriş kısmı ve giriş yolu açığa çıkartılmış olan Saray Kompleksi alanında, kent surunun yedi kapısından biri olan Kapadokya Kapısı'nda, Tapınak olarak tanımlanan kısmen kazılmış yapıda ve Yapı Bloğu 8 alanında detaylı yüzey temizliği gerçekleştirilmiş ve tüm kazı alanları tel örgüyle çevrelenerek koruma altına alınmıştır. Elbette bu tel örgü korumasının bekçi bulunmayan 
bir alanda insanları alandan uzak tutmayacağı bilindiği için açılıp kapatılabilir kapılar yapılmış ve tel örgünün kesitlere zarar verebilecek kontrolsüz gezintileri ve alanı otlak olarak kullanan hayvanların yol açabileceği tahribatı önlemeye yönelik olduğu mesajı verilmiştir. Bu noktada tel örgülerin direklerinin oldukça ince olan yaşam tabakasına zarar vermemesi için özel çaba gösterilmiş ve riskli alanlarda yüzey üzerinde taşlarla bu direkler sabitlenmiştir.

Daha önceden açılan sondaj kazı çukurlarının tekrar kapatılmış olması ve bazı alanlarda da orijinal duvar kalıntılarının toprak altına gömülerek üstte birkaç sıra yeni duvar örülmüş olması sebebiyle bu alanlarda sıkıntı olmamakla birlikte Kapadokya Kapısı ve Saray Kompleksi alanında koruma anlamında sıkıntılar tespit edilmiştir. Kapadokya Kapısı'nda duvarların kısmen restore edilmesine karşın kazı kesitlerinin korumasız olduğu ve iç avlu duvarının restore edilen kısmının yıkılmış olduğu görülmüştür. Bu kapsamda döküntüler kısmen temizlenmiş ve tel örgü sayesinde kesitlerin daha fazla tahrip edilmesinin önüne geçilmeye çalışılmıştır. Yıkılan duvar içinse kapsamlı bir proje hazırlanması gerekmesi sebebiyle herhangi bir uygulama yapılamamıştır. Dışarıdan rahatlıkla gezilerek görülebilecek durumda olan yapının giriş yolu üzerine yine bir giriş kapısı yapılarak kazı alanına girişin tehlikeli olduğuna ilişkin uyarı levhası asılmıştır. Saray kompleksi olarak tanımlanan yapının taş kaplı giriş yolunun iki kenarındaki giriş kapısına ait büyük ahşap dikmelerin kaidesi olarak tanımlanmış yerel taştan işlenmiş kaidelerin ve giriş kısmına ait bir diğer bloğun kazı sırasında sağlam ele geçmiş olmasına rağmen muhtemelen isı değişimi ve diş etkenler sebebiyle büyük ölçüde parçalanarak tahrip olduğu görülmüştür. Yolun kenar kısımlarının kazılmamış olması sebebiyle kesit toprağının baskısı ve döküntüleri bu bloklardaki tahribatı artırmıştır. Kazı alanı genişletildikten sonra kapsamlı bir restorasyona ihtiyaç duyan ve özel koruma tedbirleri alınması gereken bu bloklar için acil koruma tedbiri kapsamında detaylı temizlikleri yapılarak bloklara ait tüm parçalar bir araya toplanmış ve üzerleri jeotekstil örtü ile kapatılarak kalın bir toprak tabakası ile koruma altına alınmışlardır.

Uzun süredir devam eden bir kazı çalışması bulunmasına rağmen yöre halkının kenti otlak olarak kullanmalarının yanı sıra farklı bölgelerde hayvanları için barınaklar inşa etmiş ve etmeye de devam ettikleri görülmüştür. Özellikle Kapadokya Kapısı civarında yakın zamanda sur duvarının taşları kullanılarak yapılmış olan bir barınak antik bir yapı görüntüsü vermesinin yanında gübre kalıntılarıyla da ziyaretçilere oldukça rahatsızlık vermekteydi. Bu yapıyı yapan çobanla görüşülerek yap1 söktürülmüş ve duvar blokları ayıklanmıştır. Kentin büyük boyutu ve ulaşım yollarının bulunmayışı sebebiyle tüm alanlarda kontrol sağlanması çok kolay olmamakla birlikte, bu tip uygulamaların tüm alandan kaldırılarak tahribatın önüne geçilmesi gerekmektedir.

Yukarıda değinilen bu düzenlemelerin bir kısmı kazı bütçesiyle bir kısmı da yerel olanakların zorlanmasıyla gerçekleştirilmiştir. Acil müdahale amacı taşıyan bu düzenlemelerde öncelikli amaç korumanın bir an önce gerçekleştirilmesi olduğu için kaliteli ve pahalı malzemeler yerine imkânlar dâhilinde amacı karşılayacak ölçüde malzemeler tercih edilmiştir. Aşağıda detaylı anlatılacak olan kazı çalışmalarımız sonrasında da koruma tedbirleri dikkatli bir şekilde alınmıştır. Tüm alanlar tel örgü ile çevrelenerek kontrolsüz girişler engellenmiş ve açığa çıkartılan ve konservasyonları yapılan duvarlar toprak altına gömülmek yerine jeotekstil örtü ile ayırıcı bir tabaka oluşturularak üzerine kimi yerlerde bir-iki sıra taş duvar örülmüş kimi yerlerde de kalın bir taş tabakası ile kaplanmıştır. Böylece açığa çıkartılan kalıntıların hem sergilenmesi hem de korunması gerçekleştirilebilmiştir.

1928 yılında E. F. Schmidt (1929, 221-274) tarafından gerçekleştirilen sondajlar ve 1993 y1lından itibaren G. D. Summers (2012a, 25-27) başkanlığında yapılan çalışmalar kentin kronolojisi ve yerleşim dağılımı üzerine bilgiler sunmuştur. Bu noktada kentin büyük bölümünde tek bir 
yaşam tabakasının bulunduğu, buluntuların oldukça az olduğu ve belirli alanlarda yoğun tahribat tabakasının görüldüğü bilinmektedir. Bu nedenle kentte belirli bir yapı üzerinde çalışarak temel bilgiler edinmek yerine kentin tarihine ışık tutmak, ziyaret edilebilirliğini artırmak ve koruma tedbirlerini almak amaçlı bir strateji belirlenmiştir. Bu bağlamda kentteki kazı çalışmalarının planlanmasını yine kentin öncelikleri belirlemiştir. Ekibimizce kentin arabayla ulaşılan Doğu Kapı civarından başlayarak Saray Kompleksine kadar ulaşan yol boyunca belirli aralıklarla tespit edilen yapıların kazılması ve koruma tedbirlerinin alınarak ziyaret edilebilir hale getirilmesi amaçlı bir kazı programı belirlenmiştir.

Kente ilk kez gelen insanların antik yerleşimin nerede olduğunu anlayamamaları sebebiyle arabayla ulaşılan ilk noktada çalışma yapmanın doğru bir yaklaşım olacağı öngörülmüştür. Bu kapsamda ziyaretçilerin ve kentte dolaşan hayvanların yıllardır üzerinden geçtikleri sur duvarının doğu bölümünde kazılar gerçekleştirilmesine karar verilmiştir (Fig. 1-4). Bu dış etkenlerin haricinde arabayla ulaşılan yer olması sebebiyle uzun yıllardır modern yapıların inşası için köylüler tarafından bir taş ocağı haline getirilmiş olduğu öğrenilen bu alan akropolis tepesinin eğiminde yer aldığı için sadece insanların değil doğanın da tahribatı söz konusu olmuştur. Yağmur suları sur duvarının bu kısmından boşalmaktadır ve aynı istikamette kent dışında yer alan vadi aracılığıyla kendine yol bulmaktadır. Bu noktada kazılardan çıkartılan atık toprağın surun iç kısmında yüzey üzerinde bir set oluşturacak şekilde düzenlemesi sayesinde bu su akışının kontrol altına alınabileceği ve bu setin daha sonradan da kazı alanını sınırlayan tel örgü için bir altlık olarak kullanılabileceği öngörülmüştür. Kazılmamış yüzey üzerinde içi taş dolguyla oluşturulan bu toprak set yağmur sularının yönlendirilerek sur duvarına zarar vermeyecek başka bir noktadan çıkışında oldukça olumlu sonuç vermiştir. Bu alandaki bir diğer tahrip unsuru da hemen sur duvarının önünde yer alan köy çeşmesidir. Hem bu alanın kontrolsüz piknik alanı olarak kullanılarak kirletilmesi hem de köylülerin bu çeşmeyi akar hale getirmek için yaptıkları kontrolsüz kazılar bu alandaki tahribatı artıran unsurlar olarak tespit edilmiştir.

Alanda yapılacak kazı çalışmalarının pek çok sorunun çözüm kaynağı olabileceği öngörüsüyle çalışmalara başlanılmıştır. Kazı alanımızın başlangıç sınırını ise kentin iç kesimlerine traktör ya da jeep benzeri araçlarla geçişi sağlayan toprak yol belirlemiştir. Bu toprak yol surun bu bölümünün daha önceki evrelerde kepçeyle tahrip edilerek düzlenmesi ile oluşturulmuştur ve kentin güney bölümüne ulaşan tek yol durumundadır. Sonuç olarak, toprak yolun güney kenarından başlayan ve daha güneydeki Doğu Kapı'ya kadar uzanan alan ile Doğu Kapı'yı kazmak üzere çalışmalara başlanılmıştır. Oldukça yoğun bir taş döküntü bulunan sur duvarındaki çalışmalarımızda 2012 ve 2013 yıllarında birer aylık iki sezonda yaklaşık 2.000 metrekarelik bir alanda çalışılmış ve sur duvarının 100 m uzunluğundaki bölümü kazılarak açığa çıkartılabilmiştir. Kazı çalışmalarından ayrılmamız sebebiyle planladı̆̆ımız gibi Doğu Kapı'nın da dahil olacağı şekilde tüm alanın kazılarak açığa çıkartılması mümkün olamamıştır. İlerleyen yıllarda kazı ekibinin buradaki çalışmaları tamamlaması umulmaktadır.

Alanda yüzey temizliği çalışmalarıyla başlayan kazı çalışmalarımızda ziyaretçiler tarafından bırakılmış çok sayıda çöp ve içki şişesi gibi döküntüler toplanmıştır. Ayrıca sur duvarının ön tarafındaki kalıntılarla ilgisi olmayan taş ve moloz döküntüler kaldırılmış, su kaynakları için köylüler tarafından surun ön tarafındaki alanda açılan çukurlar da düzeltilmiştir. Alanın kentin büyük bölümünden farklı olarak daha sulak olması sebebiyle yoğun bir bitki örtüsü oluşmuştur. Bu otların yanı sıra sur duvarı üzerinde büyümüş çok sayıda dikenli bitkiden duvara zarar verenler sökülerek alan temizlenmiştir. İlerleyen süreçte bu kısımda bir ziyaretçi merkezinin ve otoparkın oluşturulabileceği öngörüsüyle yapılan çalışmalar sonucunda bilgilendirme levhalarının yerleştirildiği düzenlenmiş bir başlangıç noktası oluşturulmuştur (Fig. 4). 
Sur duvarı boyunca $5 \times 5$ metrelik açmalar şeklinde yürütülmüş olan kazı çalışmalarımızda önceliğimiz sur duvarının hatlarının belirlenmesi ve korunabilecek seviyede kazılarak konservasyonunun yapılması olmuştur. Kazı alanının eğimli oluşu ve sel suları ile gelmiş yoğun bir kum tabakasının varlığı çalışmaları zorlaştırmakla birlikte en yoğun işlem orijinalliğini kaybetmiş olan taşların alandan çıkartılarak korunmuş seviyelere ulaşılması olmuştur. Oldukça ağır bir iş yükü oluşturan bu çalışmalarda sur duvarının orijinal taşlarının yerinde korunması için yoğun dikkat ve özen gösterilmiştir. Bu noktada çalışmaları zorlaştıran bir diğer husus üstteki tabakalar alındıkça bazı bölümlerde duvar parçaların yerinden kaymış olduğunun tespit edilmesi olmuştur. Bu kaymış ve yeri net olarak bilinen bölümler kazı sırasında düzeltilerek konservasyonu yapılmış ve böylece sur duvarının iç dolgusunun bütünlüğü korunabilmiştir.

Yoğun bir kum tabakası ile kaplanmış olan surun iç kısmında çok sayıda seramik vb. buluntu ele geçmekle birlikte yüzeyde görülen bazı taşların yapı duvarlarına ait olduğunun tespit edilmesi bu alandaki kazılarımızı sınırlandırmamamızı gerektirmiştir. Daha önceki çalışmalarda sur iç duvarına bitişik yapı inşa edilmediği ve askerlerin hareket kabiliyeti ile bağlantılı olabilecek en az 5 metrelik boşluk bulunduğu belirtilmiştir (Summers 2003, 8). Surun seviyesine göre oldukça yukarıda yer alan bu yapı kalıntılarının sonraki dönemlere ait oldukları anlaşılmakla birlikte net bir tarih tespit edilememiştir. Kazılabilen küçük bir alanda duvarların sadece bir-iki sıra taştan oluştuğunun görülmesi ve tarihleme verisi tespit edilemeyişi kalıntıların yakın tarihlerden olabileceğini desteklemektedir, ancak şimdilik bu kalıntılara dokunulmaması daha doğru bir tercih olarak tespit edilmiştir. Sonuç olarak surun iç duvarının araştırılabilmesi için $50 \mathrm{~cm}$ genişliğinde ve $1 \mathrm{~m}$ derinliğinde bir kanal açılmasına ve eğime göre kademelendirilen bu kanalın oluşturulan seti aşabilecek yağmur sularının da duvara zarar vermeden dişarı atılmasına katk1 sağlayacağ1 öngörülmüştür. 2012 çalışmaları sonucunda bu kanalın işlev gördüğü ve duvara zarar gelmediğinin görülmesi üzerine 2013 yılında da aynı kazı stratejisi devam ettirilmiştir. Surun iç kısmındaki bu kum dolgunun temizlenememesi surun ön tarafinda da kazılarımızın sinırlandırılmasına sebep olmuştur. Arka taraftaki bu kazılmamış toprağın yükünün zaman

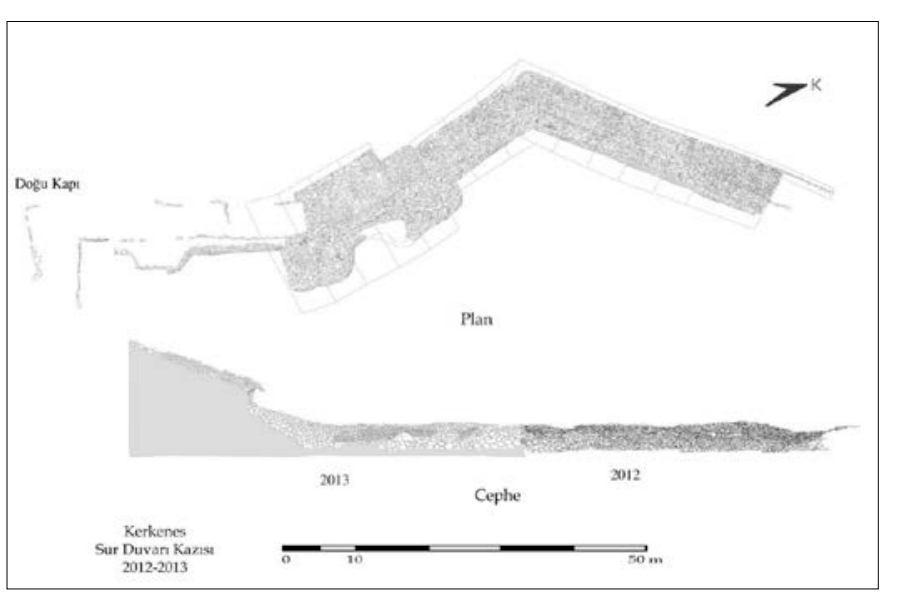

Fig. 2. Kerkenes Sur Duvarı Kazısı, çizim içerisinde ön kısmı kazılmış sur duvarının kaymasına yol açabileceği düşüncesiyle ön kısmın tamamen boşaltılmamasına ve özellikle dolgunun zarar verebileceği başlangıç kısmındaki bölümlerde eğimli destek duvarı ön kısmında temel seviyesine kadar kazılmamasına karar verilmiştir. Sonuç olarak cephe çiziminden de görülebileceği üzere güneye doğru ilerledikçe yükselen bir seviye takip edilmiş ve duvarın zarar görmeyeceği kısımlarda kazı seviyesi derinleştirilmiştir (Fig. 2).

Kazılan alanlarda açığa çıkartılarak belgelenen duvarların ve iç dolgusunu oluşturan taşların korunması en önemli önceliğimiz olmuştur. Bu bağlamda granit olan anakayadan kopartılan parçalardan inşa edilmiş sur duvarında taşların yüzeydeki dış etkenlere açık olanlarında parçalanma seviyesi oldukça yoğunken, iç kısımlarda taşların doğal yapısını korudukları gözlenmiştir. Isı değişimleri ve diğer dış etkenler yardımıyla taşların dış yüzlerinin ufalandığı ve orijinal formlarını kaybettiklerinin görülmesi sebebiyle, kazılan alanların korunması için üstleri- 
nin örtülmesinin en doğru yaklaşım olacağı tespit edilmiştir. Hem suyun geçişini yavaşlatmak hem de orijinal tabakalarla eklenen kısımların ayırt edilmesini sağlamak üzere jeotekstil örtü ile kaplanan üst yüzeylerde, duvar bulunan kısımlarda 1-2 sıra duvar örülmüş, taş dolgunun olduğu kısımlar ise yoğun bir taş tabakası ile kaplanmıştır.

Sur duvarı ve buna önde destek verecek şekilde düzenlenmiş olan eğimli destek duvarından (glacis) oluşan sur sisteminde, sur duvarının genişliği 4,5-5 $\mathrm{m}$ arasında değişmektedir, eğimli destek duvarının ise en geniş yeri olan temel seviyesinde 2,5 m genişliğe ulaştığ 1 tespit edilmiştir. Böylece toplam sur genişliği 7-7,5 m arasında değişmektedir. Sur duvarının farklı bölümlerinde de yer yer ölçü farklılıkları görülmesi kabaca işlenmiş taşların kullanılmasından kaynaklanmaktadır, tamamen işlenmiş dörtgen blokların kullanılmadığ ölçü beklemek gerçekçi değildir. Ayrıca, Arkaik Dönem yapılarının büyük bölümünde henüz standart formlara ulaşılmadığı için ufak ölçü farklılıklarının görülmesi alışılmadık bir durum değildir. Eğimli destek duvarının sura birleştiği en üst konuma kadar korunmuş kısımlarında yüksekliğin $5 \mathrm{~m}$ civarında olduğu ölçülebilmektedir. Eğimli destek duvarının en sağlam korunduğu yer olan ikinci kulede destek duvarının eğiminin bittiği alanda sur duvarının yukarıya doğru devam ettiği tespit edilmiştir. Bu durum Kapadokya Kapısı'nda olduğu gibi (Summers 2012c, 540-541) eğimli destek duvarının üst bitiminden itibaren duvarın taştan devam ettiğini göstermektedir. Üst kısımların korunmamış olması sur duvarının yüksekliği ya da mazgalların biçimi hakkında kesin bir yargıda bulunulmasını engellemektedir. Sur duvarının yüksekliği için surun eğimli destek duvarı ile birlikte 7-7,5 metreye ulaşan genişliğinin belirleyici olması mümkündür. Böylece daha önceden önerildiği gibi (Branting 2004, 47-48) eğimli destek duvarı üzerinde mazgallarla birlikte 2-2,5 m civarında bir sur yükseltisi bulunduğunu önermek şu an için olası gözükmektedir.

Doğu Kapı’nın kuzey kısmındaki dik yamacın bittiği ve surun görece düzlükte yer aldığı k1sımda iki adet kule yer almaktadır. Eğimli Destek Duvarı içerisinde oluşturulmuş olan kuleler yaklaşık $11 \mathrm{~m}$ cephe genişliğine sahip olup 6 metre derinliktedir. İkinci kulenin güney yanında sur duvarındaki içe dönüşü gidermek için derinlik artırılmış ve kuzey yanda $6 \mathrm{~m}$ olan derinlik güney yanda 9 m olarak inşa edilmiştir. Doğu Kapı'nın alt kısmında tespit edilen üçüncü kule tam olarak kazılmamış olmakla birlikte $9 \mathrm{~m}$ cephe genişliğine ve $5 \mathrm{~m}$ derinliğe sahip olmasıyla biraz daha küçük olduğu tespit edilebilmektedir. (Fig. 2) Tespit edilen 3 kuleden sadece ortadaki kule daha önceki çalışmalarda tespit edilerek kent planına kule olarak işaretlenmiştir. Çalışmalarımız sonucunda açığa çıkartılan bu kuleler kent planında görülenlerden çok daha fazla sayıda kulenin bulunmuş olduğunu göstermektedir.

Yukarıda değinildiği gibi kazı yaptığımız alan bir vadiye bakmaktadır ve düz bir kısımdan sonra birden dikleşen bir yamaç ile Doğu Kapı'ya ulaşılmaktadır. Bugün kente ulaşan karayolunun eskiden var olan bir yolun düzenlenmiş bir formu olup olmadığı ya da ne zaman açılmış olduğu net olarak bilinmese de araziye bakıldığında güney doğudaki düzlüklerden kente ulaşan en yumuşak eğimlerden birisinin bu kısımda olduğu görülmektedir. Böylece mimar ve mühendislerin hem arazinin vadi başlangıcı olan formunu hem de uygun eğim sebebiyle olası düşman sald1rılarını dikkate alarak bu kısmı düzenlemek zorunda kaldığı söylenebilmektedir. Bununla karşın, kuzeyden yamaç eğimini takip ederek düz bir hatta gelen sur duvarının birinci kuleden $12 \mathrm{~m}$ önce içe doğru dirsek yapan keskin bir dönüşe sahip olması ilginçtir (Fig. 2). Sur hattına bakıld1ğında daha yumuşak bir dönüşle gelebilecekken sur duvarının savunma zafiyeti yaratabilecek bir iç köşeyle inşa edilmiş olması akla çeşitli sorular getirmektedir. İlk akla gelen sur duvarı bölümlerinin farklı ekiplerce yapılmış olabileceği ve dönüşün de bu yüzden zorunlu olarak eklenmiş olabileceğidir. Bugün de bazı anıtsal yapılarda mimarların birleşim yerlerini denk getire- 
memek gibi hatalar yapmış olduğu akla gelince bu olasılık her ne kadar mümkün gözükse de sağlam temel arayışı daha ikna edici bir açıklama gibi gözükmektedir. Kuzeyden itibaren yamaç kenarını takip ederek gelen ve kayalık bir zemin üzerinde oturmuş sur duvarının bu kısımda aşağıda değinileceği üzere kumluk bir alan üzerinde inşa edilmesi gerekmiştir. Bu nedenle mümkün olduğunca yamaç kenarı ve kayalık tabanının takip edilmeye çalışılmış olduğu düşünülebilir. Gerekçe ne olursa olsun mimarın bu kısımda ilave tedbirler almış olması bu sıkıntının farkında olduğunu göstermektedir. Bu tedbirlerden ilki köşenin $12 \mathrm{~m}$ ilerisine düzlük kısımda bir kule inşa edilmiş olması ve bunun $5 \mathrm{~m}$ güneyinde yamacın başlangıç kısmında da ikinci kulenin inşa edilmesidir. Böylece kuleler aracılığıyla hem iç köşenin korunması sağlanmış hem de bu düzlükten gelebilecek saldırılara karşı ilave koruma tedbirleri alınabilmiştir. Bir diğer detay da bu kısımda eğimli destek duvarı kaplamalarının daha büyük bloklardan oluşturulmasıdır, böylece surun sağlamlığı artırılmak istenmiş olmalıdır.

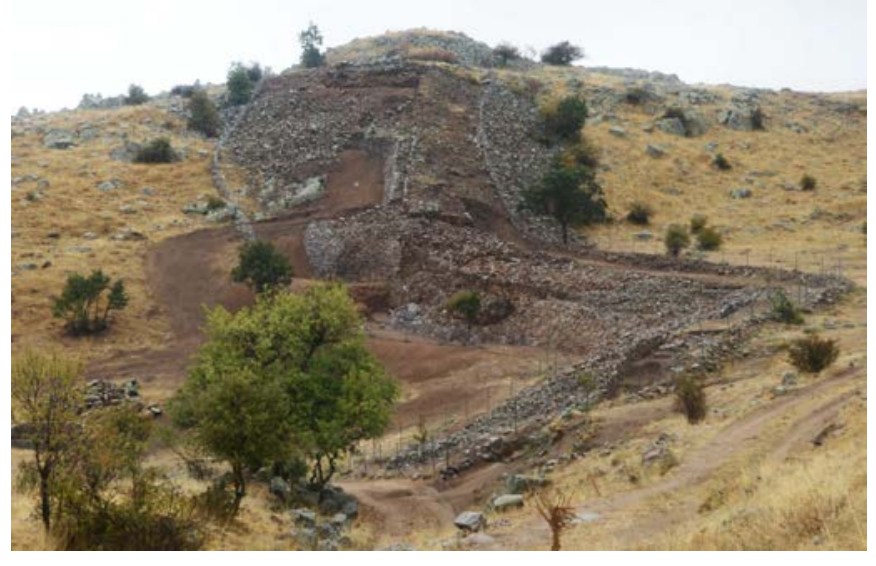

Fig. 3. Kerkenes Sur Duvarı Kazısı, kuzeyden görünüm

İlgi çekici bir diğer unsur da sur duvarının bu kısımda genişliğinin artırılmış olmasıdır. Birinci ve ikinci kulelerin eksenleri arasında kademeli olarak içe doğru artırılan sur duvarı genişliği en geniş yerinde 8,5 metreye ulaşmaktadır. Kulelerin derinligiyle birlikte 14-14,5 metreye ulaşan sur genişliği görülmektedir. Bu geniş duvarlar surun sağlamlığını artırma işlevini görmesinin yanı sıra daha fazla sayıda askerin bu alanda bulunabilmesine imkân sağlamış olmalıdır. Böylece hem sağlamlık temin edilmiş hem de vadi boyunca gelebilecek düşman saldırılarına karşı ilave korunma tedbiri alınmıştır. Genişletilmiş bu kesimin güney bitiminden Doğu Kapı'ya kadar olan 30 metrelik bölümün oldukça dik bir eğime sahip olması da bu genişletmenin gerekçelerinden birisi olabilir. Geniş̧letilmiş kesimin varlığı bu dik sur duvarı hattının oluşturacağı yükün de daha sağlıklı bir şekilde desteklenmesine katkı sağlamış olmalıdır. Tüm bu detaylar askeri bilgiye sahip, deneyimli mimar ve mühendislerin bu projede görev almış olduğunu ve sur sisteminin planlı bir girişim parçası olduğu konusunda ikna edici detaylardır. Bu genişletilmiş alan kulelerin üst seviyesinden daha yukarda korunmuş olmakla birlikte üst kısımda herhangi bir düzenleme ya da mekân bulunup bulunmadığını gösterebilecek bir veri tespit edilememektedir. Bu noktada yukarıda değinildiği gibi sur duvarının eğimli destek duvarından itibaren 2-2,5 $\mathrm{m}$ daha yüksek olduğu tahmin edilmekle birlikte bu genişletilmiş kesimin yamacın başlangıç kısmında olması ve daha yüksek bir üst yapıyı taşıyabilecek genişlikte olması diğer kısımlara göre bu kısmın daha yüksek yapılmış olabileceğini düşündürmektedir. Yüksekliğin artırılmasıyla hem dik yamaçtan düzlüğe geçiş kısmında statik açıdan bir zafiyet yaratılmasının önüne geçilmiş hem de ilave koruma tedbiri alınmış olmalıdır.

Çalı̧̧malarımızda tespit edilen bir detay da daha önceki yayınlarda bahsedilmeyen sur duvarlarının üstüne içeriden nasıl ulaşıldığını gösteren merdiven kalıntısının açığa çıkartılmış olmasıdır. Duvarın iç köşe yaptığı bölümün $6 \mathrm{~m}$ güneyinde duvarla bütünleşik bir biçimde inşa edilmiş merdiven $0.80 \mathrm{~m}$ civarında genişliğe sahip kabaca düzeltilmiş büyük taşlardan oluşturulmuştur (Fig. 2). Yan yana iki insanın zorlukla geçebileceği genişlikteki merdivenin bir örneği de Doğu Kapı'nın 20 m güneyinde yüzeyde tespit edilmiştir. 


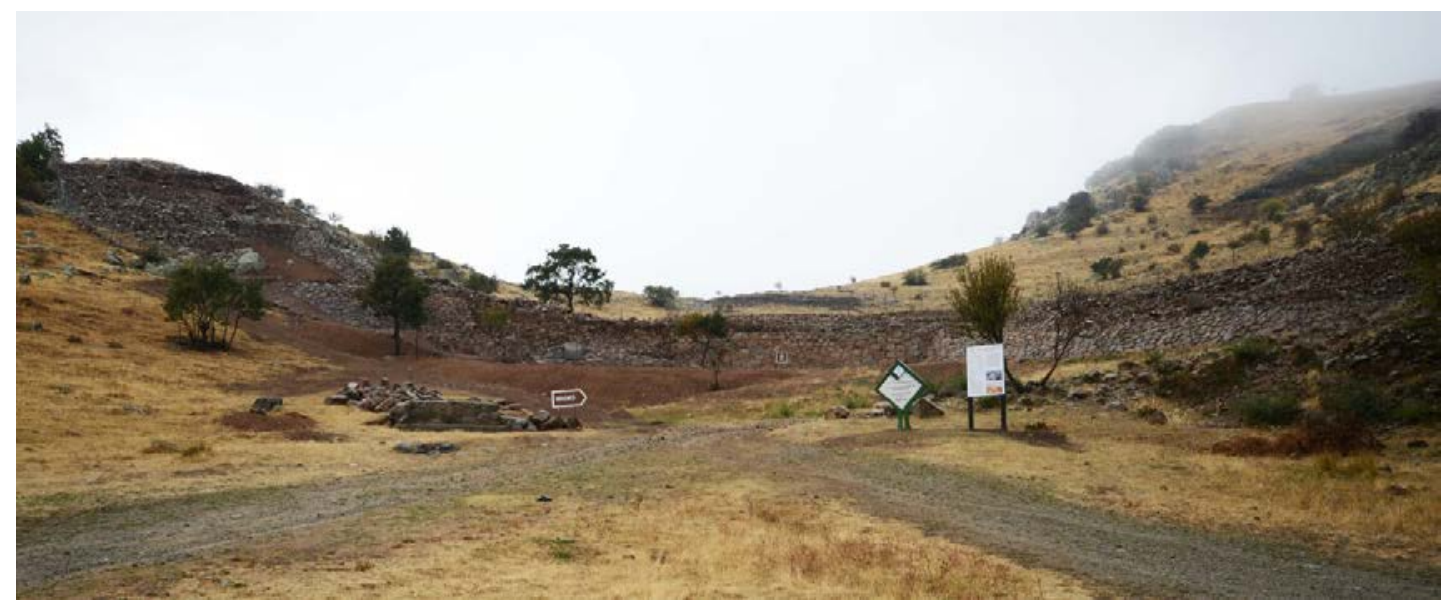

Fig. 4. Kerkenes Sur Duvarı Kazısı, doğudan görünüm

Kazı çalışmalarımıza başladığımız toprak yol yanındaki sur duvarları üst bölümleri büyük oranda tahrip olmuş durumda iken güneye doğru devam ettikçe sur duvarı ve eğimli destek duvarının görece olarak daha iyi durumda olduğu görülmüştür. Yukarıda değinildiği gibi toprak yolun açılması sırasında düzlenmiş olmanın yanı sıra bu alanın devamlı üzerinde geçilmesi tahribatın nedenleridir. Sur duvarının devamında yüzeye çok yakın olmasından kaynaklanan üst bölümlerdeki doğal tahribatların haricinde açığa çıkartılan bölümlerde yoğun veya bilinçli olabilecek bir tahribat tespit edilmemiştir. En yoğun tahribatın eğimli destek duvarında birinci kuleden hemen önce başladığı ve ikinci kule başlangıcına kadar devam ettiği görülmüştür. Olası bir savaş durumu ile ilişkilendirilebilecek herhangi bir buluntu veya tahribat tabakası tespit edilemeyen bu alanda eğimli destek duvarındaki tahribatın doğal sebeplerden ve sonraki dönemlerdeki insanların müdahalelerinden kaynaklanmış olduğu anlaşılmıştır.

Birinci kulenin kuzey köşesinde gerçekleştirilen sondaj kazısında eğimli destek duvarının kum taban üzerine inşa edilmiş olduğu görülmüştür. Bu alanda yapılan kazılarda sur duvarının dış duvar hattı ve iç dolgusunun bir bölümünün dışa doğru bir eğim gösterdiği ve bunun kum taban üzerinde inşa edilmesinin yanı sıra yukarıda değinildiği gibi bu kısımdaki dere yatağının getirdiği suyun baskısı ile ilgili olduğu görülmüsstür. Kaleden itibaren birikerek bir dere oluşturan sular, surun iç kısmında kalın bir kum tabakası yaratmıştır. Kum içinden sızan yer altı suları ise sur duvarı dolgusunu oluşturan taşların bağlayıcı unsuru olan küçük taşlar ve toprak katmanlarının duvar içerisinden dışarı atılmasına neden olmuş olmalıdır. Böylece bağlayıcı unsurlarını kaybeden duvarın hem toprak altından gelen suların baskısı hem de seviye yükseldikçe üstten akıp geçen derenin baskısıyla dışa doğru eğim göstermesi kaçınılmaz olmuştur. Eğimli destek duvarının üst bölümlerinin bu şekilde dışa doğru bir baskıyla eğilemeyeceği için yıkılmış olduğu görülmektedir. Bu tahrip olan kesimlerin kazısının yapılmasıyla yıkıntı taşlar temizlenmiş ve orijinal kalıntılar belgelenebilmiştir. Eğimli destek duvarının yıkılmış olmasına karşın sur dış duvarının sağlamlığını koruduğunun açığa çıkması bu noktada acil koruma tedbirlerinin alınmasını zorunlu kılmıştır. Öndeki taş yıkıntının kaldırılmasından sonra, arka taraftaki basıncın öne doğru yüklenmesi ve zaman içinde sur dış duvarının yıkılmasına sebep olmasının önüne geçebilmek amacıyla eğimli destek duvarının dökülen kısımlarında yeri belli olan bloklar yerlerine yerleştirilerek sağlamlaştırılmıştır. Eğimli destek duvarından iz kalmayan kısımlarda ise jeotekstil örtü ile orijinal tabakalardan ayrılarak cephe mimarisinde farklılığı bariz olarak görülebilecek şekilde daha küçük taşlardan kuru duvar tekniğinde bir destek duvarı örülmüştür. Bu konservasyon tedbirlerimiz sayesinde hem duvar bütünlügü koruma altına alınabilmiş hem de çalışanların güvenliği temin edilebilmiştir. 
Sur duvarı ve eğimli destek duvarı olarak iki bölümden oluşan sur sisteminde kullanılan teknikler benzemektedir. Duvar içerisinde bir kesit halinde kazı yapılmamış olmakla birlikte farklı seviyelerden elde edilen bilgiler aracılığıyla yapım tekniğinin tespit edilmesi mümkün olmuştur. Sur duvarı iç kısmı düzenli bir şekilde yerleştirilmiş dolgu taşlardan oluşturulmuştur. $\mathrm{Bu}$ dolgunun iç ve dişta kalan yüzleri de kabaca düzeltilmiş taşlarla oluşturulmuş birer duvar ile sınırlandırılarak sur duvarı inşa edilmiştir. Belirli bölümlerde iç ve dış duvarları birbirine bağlayan diklemesine duvarlar örülerek bölümlere ayrılmış olan duvarda sağlamlık ve yükün dengeli dağıtımı temel alınmıştır. Oluşturulan iç bölümlerde öncelikle düzenli bir şekilde yerleştirilmiş büyük taşlardan bir tabaka ile arada kalan kısımlar doldurulmuştur. Bu büyük taşların üzeri daha küçük boyutlarda taşlarla kaplanmış ve onun üzeri de çakıllı toprak ile düzlenmiştir. Kazılan alanlardan bu üç katmanlı dolgunun her 1-1,5 metrede yinelenmiş olduğu anlaşılmıştır. Hatıl olarak işlev görmüş olan en üstteki çakıllı toprak tabaka maalesef çoğu bölümde dış etkenler sebebiyle bozulmuştur. Kazı çalışmaları sonucunda bu toprak tabakanın kerpiç olabileceğine ilişkin veri tespit edilememekle birlikte orijinalinde bir çamur tabakanın kullanılmış olduğu söylenebilmektedir. Kapadokya Kapısı kazılarında ahşap kiriş kalıntısı ele geçtiği için tüm sur duvarlarında ahşap kirişlerin kullanılmış olabileceği belirtilmiştir (Summers 2013a, 143) ancak tarafımızdan yürütülen çalışmalarda sur duvarında ahşap kirişler kullanılmış olabileceğini belirtecek herhangi bir iz, kalıntı ya da ahşap kirişlerin yerleştirilebileceği bir boşluk bulunamamıştır. Eğimli destek duvarı kısmında da benzer bir teknik kullanılmıştır. Kulelerin iç kısmında kule formunda tek sıra bir duvar örgüsü ile bölümle yapıldığı ve bu duvarın hem içte hem de dışta kalan kısımlarının katmanlar oluşturacak şekilde yine önce büyük taşlar, sonra daha küçük taşlar ve çakıllı toprak tabakası ile doldurulmuş olduğu görülmüştür. Bu dolgunun dış kısmı eğimli destek duvarının formuna uygun olarak yukarı doğru daralmaktadır ve dış cephe düz form verecek şekilde yerleştirilmiş farklı ölçüler ve boyutlardaki taşlarla kaplanmıştır. Bu kaplama taşlarının bir kısmı yassı formda iken bir kısmı düz yüzeyi dışa getirilmiş alt kısmı geniş, üste doğru incelen çok köşeli taşlardır. Açığa çıkartılan kısımlarda herhangi bir alet izi veya taşçı işaretine rastlanılmamıştır ve taşlardaki doğal aşınma sürecinde mevcut izlerin aşınmış olabileceği olasıdır ancak, taşların ölçülerinin belirli bir standartta olmayışı şantiye alanına toplanan taşlardan en uygunlarının basit müdahalelerle yerlerine yerleştirilmiş olabileceğini de göstermektedir. Duvar tekniği oldukça basit ve anlaş1lır görünmekle birlikte duvar yapımına aşinalıktan öte sadece uzman kişilerin üretimi olabileceğini gösteren detaylara sahiptir.

Kerkenes sur sisteminin boyut, planlama ve teknik açıdan önceden planlanmış bilinçli bir uygulamanın ürünü olduğu ve dönemine göre ilerilikler gösterdiği net olarak anlaşılmaktadır. $\mathrm{Bu}$ durum bu ölçüde bir yapının hangi kültürdeki insanlar tarafından ve hangi otorite altında yapılmış olabileceği sorusunun önemini göstermektedir. En yakın uygulamaları Samsun Akalan, Niğde Göllüdağ, Sardeis ve Phokaia'da görülen sur sistemi ve kentin kimler tarafından kurulmuş olabileceği hakkında aşağıda ayrıntılı değerlendirmeler yapılacaktır.

Yerleşimdeki diğer kazı çalışmamız kentteki yapı bloklarından Doğu Kapı'ya yakın olan bir tanesinde gerçekleştirilmiştir. Jeofizik araştırmalarla tespit edilen yapı bloklarının büyük bölümü toprak yüzeyinde görülebilir durumdadır ve sadece görünen duvar sıralarında yapılacak ince temizlik çalışmaları bile kentin yapılarını anlamak için çok fazla katkı sağlayabilecek durumdadır. Elbette Jeofizik çalışmaların önemi tartışılmaz, ancak Kerkenes gibi kalıntıların yüzeyden bile görülebildiği bir yerleşimde jeofizik çalışmaların kentteki ana çalışma konusu haline getirilmiş olması çok doğru bir yaklaşım olarak gözükmemektedir. Çalışmaların başından beri farklı teknikler kullanılmış olan jeofizik çalışmalara harcanan emeğin kazıya ve alan temizliğine harcanması durumda çok daha fazla bilgi edinilebileceği araziyi gören ve hatta uydu fotoğraflarından bakan herkesin kolaylıkla ulaşabileceği bir sonuçtur. Uzun soluklu kazı planımıza uygun 
olarak yüzeyde görülebilir durumdaki kalıntılardan büyük bir yapı bloğu olduğu anlaşılan, Doğu Kapı'ya yakın bir alanda konut yerleşimlerinin anlaşılabilmesi amacıyla kazı çalışmaları başlatılmıştır. Bu alanın seçilmesindeki amaç yine eğimli bir arazide yer alan ve üst kısmı hem dere yatağ 1 hem de geçit haline geldiği için yoğun tahribata uğrayan yapının daha fazla tahrip olmasının önüne geçerek koruma ve araştırma faaliyetlerinin birlikte yürütülmesidir. Çalışmalarımızda yapının güneydoğu köşesinde duvarlar boyunca $5 \times 5$ m ölçülerinde 12 adet açma açılmıştır (Fig. 5). Önceki kazı verilerine ulaşılamadığından dolayı kent planında kaç numaralı yapı bloğu olduğunu bilemediğimiz için bir numara verilemeyen yapıdaki kazılarımız, ağırlıklı olarak tabakaları anlamak amaçlı gerçekleştirilmiştir. Yapının eğimli bir alanda yer alışının getirdiği olumsuzlukların başında yağmur sularının kaleden itibaren toplanarak bu yapının üzerinden geçmesi sebebiyle toprağın erozyona uğraması ve yapı duvarlarının da en azından üst bloklarının eğime uygun olarak kaymış olmasıdır. Ayrıca, üzerinden devamlı yaya ve hayvanların geçiş yapması toprağın oldukça sertleşmesine ve bir kısım yapı taşlarının yerlerinden sökülmesine yol açmıştır.

Çalışmalar sonrasında 16x13 m ölçülerinde güneybatıya bakan megaron formunda bir ana yapı ile ona daha sonradan eklenmiş mekanlara ait duvarlar kısmen açığa çıkartılmıştır. Megaronun ön odasının ön kismında tespit edilen taş tabanın sadece küçük bir bölümü kazılabilmekle birlikte bu kısımdaki bölümün avlu olarak düzenlenmiş olduğu anlaşılmıştır. Megaronun kuzey batı kısmındaki alanda ise depo şeklinde küçük mekanlardan oluşan uzun bir mekan dizisi ile önündeki taş kaplı avlunun küçük bir bölümü kazılabilmiştir. Megarona göre diyagonal yerleştirilen bu uzun mekan

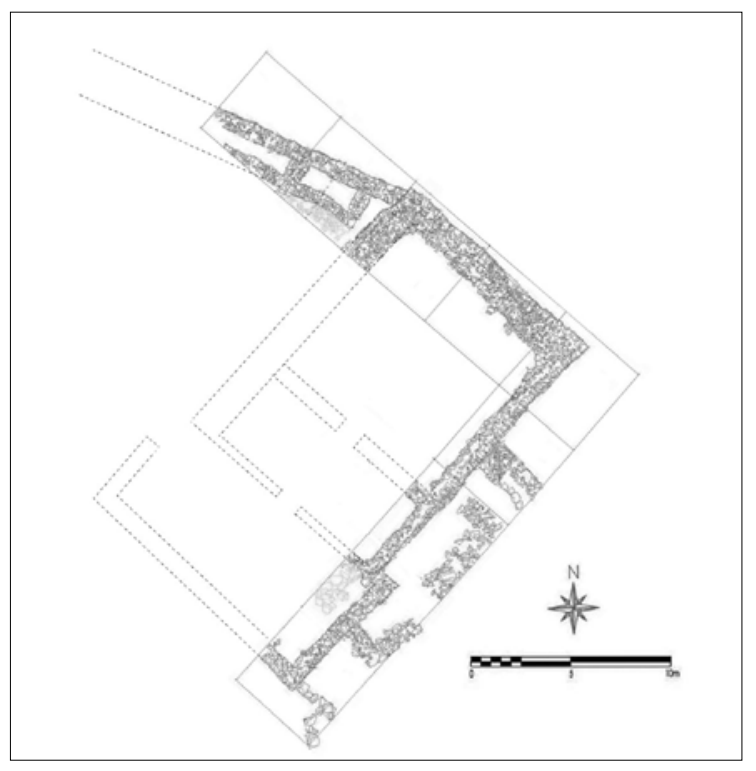

Fig. 5. Yapı Bloğu Kazısı, plan dizisinin organik bağ göstermeyen köşeleriyle sonraki dönemde ya da yapıdan bağımsız bir şekilde eş zamanlı inşa edilmiş olduğu anlaşılmıştır. Megaronun güney bölümünde kısmen açığa çıkartılmış duvarlar da köşelerin gösterdiği üzere organik bağ göstermemektedir. Kazılan bölümlerde esas amaç duvarları takip ederek yapı formunu anlamak olduğu için ilk aşamada mekan iç kısımları kazılmamıştır. Duvar kenarlarında yer yer tespit edilen kerpiç kalıntıları duvarların üst bölümlerinin kerpiçten yapılmış olabileceğini göstermektedir, ancak oldukça yoğun tahribat gören bu bölümler için kazılar genişletilmeden kesin yargıda bulunmak zordur. Yapının aşağıda kalan arka kısmında duvarların öndekilere göre oldukça kalın olduğu görülmektedir, bu durum muhtemelen yapının eğimli bir alanda inşa edilmiş olmasıyla ilgilidir. Yapıda seviyeyi ayarlamak için eğimli alanda aşağıda kalan kısımlarda daha yüksek taş duvarlar inşa edebilmek için duvar kalınlıkları artırılmış olmalıdır.

Oldukça tahribata uğramış ve kazısı tamamlanmamış olan yapıda ele geçen buluntular daha önceden kentte farklı bölümlerden tanımlanan buluntulardan farklılık göstermemektedir. MÖ VI. yüzyılın ilk yarısına ait olabilecek geometrik bezemeli, bantlı ya da bezemesiz seramiklerin arasında en dikkat çekici buluntular megaronun ön oda dış köşesinde ele geçen depo kabı parçaları ile büyük bölümü tamamlanabilen yonca ağızlı bir sürahidir (Baran 2015, Fig.10-11). Bu bölümde megaronun dışına eklenmiş duvarların mutfak olarak kullanılmış olabilecek bir mekanı sınırlamış olabileceğini gösteren çok sayıda seramik parçası da ele geçmekle birlikte kazı çalış- 
maları tamamlanmadığı için kesin bir tanımlama yapılamamıştır.

Daha önceki jeofizik araştırmalarında tespit edilen yapı bloklarında da görüldüğü gibi bir ana mekan ve ona eklenmiş duvarlarla düzenlenmiş bir forma sahip olan yapı bloğu kazıları kentin yerleşim tabakalarını öğrenmemiz açısından oldukça katkı sağlamıştır. Kısa bir dönemde küçük bir ekiple yürüttügümmüz bu çalışmalar oldukça ince bir yaşam katmanı bulunan yerleşimdeki kalıntıların bu şekilde kazılmış olması durumunda kentle ilgili ne çok bilginin şimdiye değin edinilmiş olabileceğini göstermektedir.

Kazı çalışmaları sonrasında açığa çıkartılan duvarların korunması için duvar üstlerine hem ayırıcı tabaka oluşturması hem de yağmur sularının duvar içine geçişini yavaşlatarak yapıya zarar vermesinin önüne geçmek üzere duvarların sadece üst kısımlarına jeotekstil örtü serilmiş ve duvarlar birkaç sıra yükseltilerek koruma altına alınmıştır. Tel örgüyle çevrelenerek koruma altına alınan kazı alanının dere yatağında bulunması sebebiyle yapının dış kısmına gelecek şekilde güneydeki üst seviyeye kazı atık toprakları ile bir set oluşturulmuştur. Böylece yağmur sularının yapının üzerinden değil set aracılı̆̆ıyla yan kısımlardan zarar vermeyecek şekilde geçişi sağlanmıştır. Kazı çalışmalarımızın devam etmemesi sebebiyle bu alandaki çalışmalar tüm verileriyle birlikte yeni ekibe bırakılmıştır.

\section{Kerkenes Dağı Yerleşimi Üzerine Değerlendirmeler}

\section{Araştırma Tarihçesi ve Pteria Tanımı}

Yerleşimin tespit edildiği ilk araştırmalardan itibaren ismi ve dönemi hakkında çok yoğun tartışmalar yaşanmıştır. Kerkenes'teki yerleşimden bahseden ilk araştırmacı E. Huntington (1901, 208-209) kenti ziyaret etmediğini belirterek çevresindeki tepelerle birlikte Hitit yerleşimi olarak tanımlamıştır. İlk olarak 1899 yılında J. G. C Anderson (1903, 26-29) tarafından ziyarete edilerek kısaca tanıtılan Kerkenes'in Mithridation olabileceği önerilmiştir. 1927 yılında H. H. von der Osten (1928, 83 vd.) tarafindan ilk çalışma gerçekleştirilmiş olan yerleşimin bu evrede surları incelenmiş ve planı oluşturulmuştur. 1928 yılında E. F. Schmidt (1929, 221 vd.) bir Hitit yerleşimi olabileceği düşüncesiyle sondaj kazıları gerçekleştirmiştir. 7 günlük bir çalışma sonucunda kentin farklı noktalarında 14 sondaj açmış olan Schmidt yerleşimin kesinlikle Hitit dönemi veya öncesine ait olmadığını ve Alişar'daki Hitit sonrası tabakalarla karşılaştırılabileceğini tespit etmiştir. Kentin ismi ile ilgili olarak ise ilk tanımlama S. Przeworski (1929, 312-315) tarafından 1929 yılında Pteira olabileceği şeklinde yapılmıştır. 1993 yılından 2011 yılına kadar kent ve çevresinde çalışmalar yürütmüş olan G. D. Summers ve ekibi tarafindan kentin tanımlamasında, buluntulara göre değişen öneriler yapılmıştır. İlk çalışmalarda bir imparatorluk merkezi olarak kalıcı amaçla kurulduğu belirtilen kentin Pteria olarak tanımlanabileceği ve MÖ 585 sonrasında Medler tarafından kurulmuş olabileceği belirtilmiştir (Summers 1996, 207 vd ; 1997, 81 vd.; 2000, 55 vd.). 2003 yılından itibaren kentte yürütülen k1smi kazılarda Phryg buluntuları ve yazıtlarının ele geçmesi sonrasında MÖ VI. yüzyıl başlarında Phryg kökenli bir halkın kurduğu ve Medleri destekledikleri için Kroisos tarafından tahrip edilmiş bir kent tanımı önerilmiştir (Summers 2004, 7-41; 2006a, 182-183; 2006b, 653; 2009, 657 vd.). Daha sonraki çalışmalarda en erken MÖ VII. yüzyıl ortasından sonra kurulmuş olabilecek bu kentin bağımsız Pteria Krall1$\breve{g} 1$ olarak tanımlanması yoluna gidilmiştir. Kentteki tüm kültürel ve mimari unsurların kent halkının Phryg kökenli olduğuna işaret ettiği, ancak Kerkenes’in Gordion-Ankara civarından değil, daha batı veya güneybatıdan gelmiş halklar tarafından kurulmuş olması gerektiği önerilmiştir. Lydia'nın yayılmacı politikasından kaçan halkların kaçış için değil, ama güçlü bir oluşum olarak burada ortaya çıkmış olabilecekleri ve Pteria'nın orijinal Phryg ismi ne olursa olsun bu alanda bağımsız bir krallık olarak gözüktüğü önerilmiştir. Kentin Medleri desteklemesi sonu- 
cunda ise Kroisos tarafindan ele geçirildiği ve muhtemelen Sardeis’e döndüğünde Kyros kenti kışın kullanmasın diye Kroisos tarafindan yakılmış olduğu önerilmiştir (Summers 2012b, 26; 2013a, 155-156; 2014, 46-49). Son yıllarda ise aşağıda değinileceği üzere kentteki batı etkisi daha fazla dile getirilmeye başlanmıştır.

Pteria'nın Kerkenes olarak tanımlamasının uygun olmadığına ilişkin düşünceler de varlığını korumaktadır (Rollinger 2003b, 321-326; Michels 2011, 695). Örneğin P. Högemann (1999, 858) ve C. Tuplin $(2004,242)$ Pteria'nın Mazaka/Kayseri olabileceğini önermiştir. A. M. Wittke (2014, 745 vd.) ise Herodotos'un verdiği bilgilerdeki tutarsızlıklar ve tarihsel gelişimler dikkate alındığında Pteria'nın Kerkenes olarak tanımlanmasının sorgulanabileceği ve Pteria'nın daha farklı bir yerde muhtemelen daha güneyde aranabileceğini öne sürmüştür. Pteria'nın farklı tanımlamalarından en eskisi ve yaygın olanı Boğazköy'dür. C. Texier (1839, 209 vd.) yaptığı gezilerde Boğazköy’u görmüş ve Pteria olabileceğini önermiştir, daha sonradan bu görüş pek çok araştırmacı tarafindan kabul görmüş ve kazı ekibi de Boğazköy'ü Pteria olarak kabul etmişlerdir (Bittel 1970, 155-156; Bossert 2000, 171-174). Pteria olarak tanımlanan bir diğer merkez ise Samsun yakınındaki Akalan'dır. İlk kazılar sonrasında yapılan Akalan'ın Pteria olabileceği önerisi 2000'lerde yeniden dile getirmiştir. Akalan'in Sinope'ye 120 km, Kerkenes'in ise 400 km uzaklıkta olduğu ve Herodotos'un Pteria, Sinope yöresindedir şeklinde aktarması sebebiyle kronolojik olarak Herodotos'un tanımlarına uyan Akalan'ın Pteria olarak tanımlanmasının daha uygun olduğu öne sürülmüştür (Dönmez 2004, 74-77).

Antikçağ verilerine bakıldığında Kerkenes ile bağlantı kurulan en temel bilginin Herodotos'un aktarımlarındaki Pteria olduğu görülmektedir.

I. 76: “Kroisos, ordusuyla birlikte ırmağı aştıktan sonra Kapadokya'da Pteria denilen yöreye vardl. (Pteria bu bölgenin en sağlam yeridir; aşağı yukarı Karadeniz'in tanınmış kentlerinden Sinop yörelerine düşer). Orada konakladı ve Suriyelilerin yurtlarını yağma etti; ülkenin bașkentini aldı ve halkını köleleştirdi; çevrede köy, kasaba ne varsa hepsini aldı ve kendisine hiçbir zararları dokunmamış olan Suriyelileri göç etmek zorunda bıraktı. Kyros ordusunu toplamıștı ve aralarından geçtiği bütün halklardan da beslenip gücünü artırarak Kroisos'a karşı yürüyüsse geçmişti. Onu topraklarından atmak için yola çıkmadan önce Ionialılara elçiler göndermiş, Kroisos'a karşı ayaklandırmayı denemiști. Ionialılar kulak asmadılar. Sonunda Kyros, Kroisos'a ulaștı ve geldi Pteria'da onun karşısında konakladl, ișe başladılar ve birbirlerinin boyunu ölçtüler. Büyük savaş oldu, iki yandan da çok adam düştü; sonunda gece ayırdı onları birbirlerinden, yenen yenilen belli olmadı" (terc. M. Ökmen).

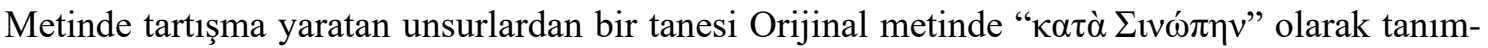
lanan Pteria'nın Sinope ile olan ilişkisidir. Türkçe çevirisinde "Sinope yörelerinde" olarak çevrilmişken, farklı çevirilerde Sinope ile aynı hizada "lies on the line of the city of Sinope" (terc. A. D. Godley), "lies more or less in a line with the city of Sinope (terc. J. Marincola)") şeklinde çevrilmiştir. Pek çok anlama gelebilen " $k \alpha \tau \alpha$ ” ifadesi Herodotos tarafindan birbirine yakın yerlerin tanımlamasında kullanılmıştır. Bununla birlikte Pteria ile ilgili kısımda " $\mu \alpha \dot{\lambda} \imath \sigma \tau \dot{\alpha} \kappa \eta$ " yani "yaklaşık olarak" ifadesiyle birlikte geçmesi sebebiyle çevirisinde "yaklaşık olarak yakınında" terimi yerine "yaklaşık olarak aynı hizada" çevirisi büyük oranda kabul görmüştür (Tuplin 2004, 247). Yukarıda değinildiği gibi Boğazköy ve sonrasında da Kerkenes'in Kapadokya'da yer alan Pteria kenti olarak tanımlanmasında da genel olarak bu çeviri temel alınmaktadır. Pteria'nın Samsun'daki Akalan'da tanımlanması ise bu çevirinin Sinope yakınında olarak kabul 
edilmesinden kaynaklanmaktadır.

Herodotos'un metnine baktığımızda ise aslında Pteria'nın kent olarak tanımlanabileceğine dair kesin bir ifade kullanmamış olduğu görülür. Her ne kadar Herodotos "Pteria yöresi", "Pteria bu bölgenin en sağlam yeridir", "Pterialıların başkentini aldı" ve "Pteria'da onun karşısında konakladl" ifadelerini kullanmış olsa da aslında bu ifadelerin hiçbiri Pteria'nın bir kent olduğu anlamını vermemektedir. Bu noktada çevirilerden kaynaklanan bir diğer farklılık da Türkçe çeviride "ülkenin başkenti (Herodotos 1991)" olarak geçen ifadenin diğer çevirilerde "the city of the Pterians (terc. A. D. Godley)" veya "the main city of Pterians (terc. J. Marincola)" şeklinde Pterialıların kenti veya Pterialıların ana kenti şeklinde çevrilmiş olmasıdır. Araştırmacıların büyük bölümü Kyros ve Kroisos arasında geçen savaşın Herodotos tarafindan belirtildiği gibi Pteria Bölgesinde değil, Pteria adındaki bir kentin yakınında geçtiğini varsaymaktadır. Bu nedenle yukarıda değinildiği gibi 19. yüzyıl itibarıyla araştırmacılar tarafından Pteria kentinin lokalizasyonu için çok farklı öneriler getirilmiştir. Ancak döneminin en büyük boyutlu yerleşimi olan Kerkenes'ten neden Herodotos tarafından bahsedilmediği önemli bir sorudur. Bu kadar büyük ve korunaklı bir kentin kolay ele geçirilemeyeceğini ve eğer Kroisos burayı ele geçirdiyse bunun büyük bir başarı hikayesi şeklinde aktarılmasını beklemek, özellikle de Kyros ile savaşta çok büyük rol oynamış olacağını varsaymak çok gerçek dışı gözükmemektedir.

Herodotos haricinde Pteria'dan bahseden ve hatta Pteria'yı bir kent olarak tanımlayan tek antik yazar Stephanos Byzantinos'tur ve iki farklı Pteria kentini tanımlamaktadır. Bunlardan ilki Med kenti Pterion veya Pteria, diğeri ise Sinope yakınlarındaki Pteria'dır. Her ne kadar Przeworski $(1929,315)$ ve daha sonra Summers $(1997,94)$ tarafindan Pteria tanımlamasını doğrulayan bir veri olarak kullanılmış olsa da genel kanı Stephanos'un bu tanımlamayı Herodotos'un verdiği bilgilerden türettiği ve muhtemelen yanlış aktarılmış olduğu yönündedir (Tuplin 2004, 247). Pteria kenti için bir diğer antik veri ise son yıllarda Gieesen papyruslarının yeniden okunmasından sonra tespit edilen Sinope yakınlarındaki Pteria ifadesidir. Çok net bir veri olarak kullanılması mümkün olmayan bu aktarımda Karadeniz yakınlarında bir Pteria'dan bahsedilmekle birlikte farklı bir yerleşimden bahsedildiği ya da Herodotos'taki bilgilerin sonraki dönem yanlış aktarımından kaynaklanmış olabileceği düşünülmektedir (Kuhlmann 1994, 131-136; Tuplin 2004, 247-248).

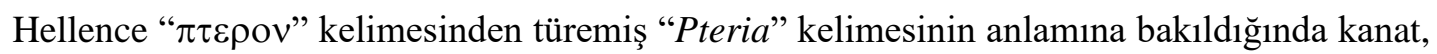
kanat benzeri ya da tüy anlamı karşımıza çıkmaktadır. Mimaride tapınağın kenarlarında yer alan sütun sıraları anlamına gelen kelimenin " $\pi \tau \varepsilon \rho v \xi$ ” versiyonu ise "kanat gibi kaplayan ya da koruyan bir şey" olarak çevrilmektedir (Liddell 1940). Bu kelimenin seçiminin tesadüfi olamayacağ 1 ve Herodotos tarafından gerçek anlamı muhtemelen bilinmeden kullanılmış olabileceği varsayılabilir. Her ne kadar kentin orijinal Phryg ismi yerine Herodotos tarafindan Hellence Pteria kelimesinin kullanılmış olabileceği düşünülmekle (Summers 2014, 46-47) birlikte Herodotos tarafından gerçek anlamıyla yani Lydia egemenlik sahasının en uç kanadını ifade etmek için kullanılmış olan kelime aktarılmış olmalıdır. Bu kapsamda 50-60 senelik bir süreçte yerleşim görmüş olduğu bilinen Kerkenes'in aslında isminin olmadığ 1 ve Herodotos tarafından Sinop hizasındaki bu kanat bölgesini, yani Lydia sınır hattını belirtmek amacıyla kullanılan Pteria kelimesinin aktarılmış olması çok mantıklı bir açıklama olarak önerilebilir. Lydia krallığının yıkılması sonrasında bölgenin önemini yitirmiş olduğu ve kentin de sonraki süreçte yerleşim görmemesi sebebiyle Herodotos'un bölge ismi olarak verdiği Lydia Krallığının sınır hattını betimleyen Pteria kelimesi bir daha kullanılmamış olmalıdır. Daha sonraki dönemlere ait küçük veriler de doğal olarak Herodotos'un metnini okuyanların varsayımlarına bağlı aktarımlar olmalıdır. Bu noktada, Pteria'nın bir kent ismi olması durumunda daha fazla kaynakta bahsedilmesini bek- 
lemek gerekirdi ve aynı şekilde, bazı araştırmacılar tarafından önerildiği gibi Kerkenes, Boğazköy, Akalan, Mazaka veya başka bir yerleşim Pteria olsaydı buralarda devam eden kesintisiz yaşam sebebiyle kent isminin de kullanılmaya devam edileceğini beklemek gerektiği akıldan uzak tutulmamalıdır.

\section{Tarihsel Gelişim}

G. Summers tarafından yürütülen çalışmalarda kesin bir tarih tespit edilemese de yaklaşık bir kuruluş tarihi önerilebilmiştir. Demir Çağ seramiğinin henüz kesin bir kronolojisi bulunmadığı için ve daha kesin kronolojiye sahip Batı Anadolu Seramiğinin ise henüz Kerkenes'te ele geçmemiş olması sebebiyle tarihleme için Alişar kazısında ele geçen seramikler ve tabakaları temel alınmıştır. Alişar IV. tabaka seramik örneklerinden Kerkenes'te ele geçmemiş oluşu kentin MÖ VII. yüzyıl sonlarında kurulmuş olduğunu düşündürmektedir. Kentteki tüm buluntuların ve mimarinin Phryg kültürüne ait olması sebebiyle halkının Phryg kökenli olduğu ve muhtemelen Ankara-Gordion hattının daha batı veya güneybatısından gelmiş oldukları önerilmiştir. G. Summers $(2014,46)$ kesin bir sebep belirtmese de bu halkın kaçaklardan değil Lydia'nın genişleme politikasından uzaklaşan insanlar olabileceğini ve burada güçlü bir otoriteyi simgeleyecek şekilde yeni bir bağımsız krallık olarak kentlerini kurmuş olduklarını önermektedir. Phryg krallığının yıkıldığı bir dönemde bu denli büyük ve güçlü bir yerleşimin Phryg kökenli bir halk tarafindan kurulmuş olması oldukça dikkatli yaklaşılması gereken bir öneridir.

Kentin MÖ VII. yüzyı1 sonlarındaki kuruluş dönemine bakıldığında siyasi ortamın oldukça karışık olduğu ve yazılı kaynaklarda bu dönemle ilgili verilerin oldukça sınırlı olduğu görülmektedir. Herodotos tarafindan bu dönemlerle ilgili aktarılan veriler Alyattes tarafindan Kimmerlerin Asya'dan sürülmüş olduğu ve Medler ile Lydialıların arasındaki mücadele ile ilgilidir. Herodotos, Med kralı Kyaksares'e isyan eden İskitlerin Kyaksares'in oğlunu öldürdükten sonra Lydia Kralı Alyattes'e sığındıklarını ve bu olayın Medlerle Lydialıların 5 yıl süren savaşına sebep olduğunu aktarır.

I. 16: “....sonra Alyattes geldi. Bu, Medlerden Deiokes soyundan Kyaksares'e karşı savaş açtı, Kimmerleri, Asya'dan sürdü (Ter. M. Ökmen).

I. 73. "Bunlar, Kyaksares tarafindan küçük düşürülmüş ve yüzlerine layık olmadıkları bir kara çalınmıs saydılar kendilerini, yanlarına verilmiş olan çocuklardan birini doğrayıp, avda yakaladıkları hayvanları her zaman yaptıkları gibi, güzel bir parça pişirip Kyaksares'in önüne sürmeye karar verdiler, bu armağanı sunacak ve sonra hemen kisa yoldan Sardes'e, Sadyattes oğlu Alyattes'in yanına gideceklerdi. Öyle yaptılar: Kyaksares ve konuklarl yediler bu eti ve İskitler bu marifetten sonra yalvarıp yakararak Alyattes'in yanina geldiler. (I. 74) Kyaksares bunlart geri istedi, ama Alyattes vermedi. Bu yüzden Lydialılarla Medler arasında beş yıl süren bir savaş çıktı, sık sık Medler Lydialıları dövdüler, sık sik da onlar tarafindan dövüldüler. Hele bir seferinde tuhaf bir gece savaşına da tutuştular; savaş denk koşullar altında sürüyordu ki, altıncı yılda, bir çarpışma sırasında ve ortalı̆̆ın en çok karışmış olduğu bir anda gündüz, birden yerini karanlığa bıraktı. Bu ışık tutulmasını Miletoslu Thales, Ionialılara daha önceden bildirmişti; yılına, gününe kadar. Ama Lydialılar ve Medler gün ortasında gece olduğunu görünce, çarpışmayı kestiler ve hemen bir anlaşma, bir barı̧̧ sözleşmesi yaptılar. Kilikyalı Syennesis ve Babilli Labynetos'u kendilerine aracı seçtiler. Bunlar, barış 
yeminleri getirip götürmektense, iki kralı bir araya getirecek bir evlenme tezgâhladılar; Alyattes, kızı Aryenis'i Kyaksares'in oğluna, Astyages'e versin, dediler; zira băg sağlam olmazsa uzlaşma dayanıksız olur. - Bu halklarda yemin Yunanlılarda olduğu gibidir, ayrıca bir de kollarının derisini çizip karşılıklı kanlarını yalarlar" (Ter. M. Ökmen).

Herodotos, savaşın gerekçesi olarak İskitlerin Alyattes'e sığınması ve Medlere geri verilmemesini göstermekle birlikte savaş durumunda yaşanan siyasi ilişkileri yansıtan bu aktarım gerçeğin değiştirilmiş hali olmalıdır. Kimmerleri Asya'dan kovduğu aktarılan Alyattes'in, Kimmerleri kovalayarak Anadolu'ya girmiş olan ve bir taraftan da Medlerle mücadele eden İskitler ile siyasi bir bağlantı kurmuş olması çok mantıksız bir açıklama değildir (Cobbe 1967, 25). Bu evrede Asur kralına elçi gönderen Gyges'in tüm Lydia'yı çekirgeler gibi kaplamış olan Kimmerlere karşı yardım talep etmiş olduğunun bilinmesi (Ivantchik 2010, 41-43) benzer müttefiklik ilişkisinin İskitler ve Lydialılar arasında da yaşanmış olabileceğini düşündürmektedir. Kimmerleri yenen Lydialıların güçlenmesi ve kuzeyden kendisine sikınt yaratan İskitler ile işbirliği yapması Medler için savaş gerekçesi sayılmış olmalıdır.

Herodotos (I. 74) Med savaşını anlatırken özel bir konum

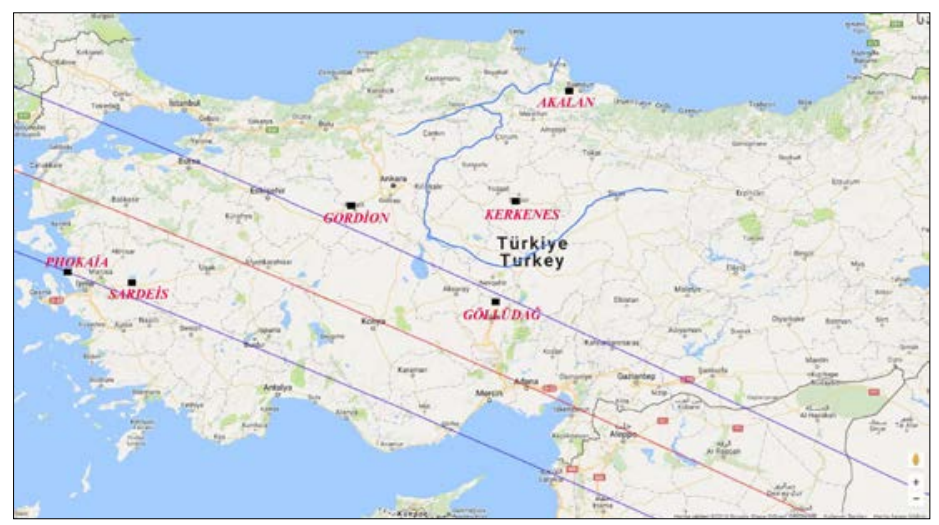

Fig. 6. 28 Mayıs 584 tarihinde gerçekleşen güneş tutulmasının hattı ve yerleşimlerim konumu

belirtmemektedir. 6. yılında sona eren bu savaşın tam olarak nerede ve nasıl gerçekleştiği ve neden Kilikya ve Babil krallarının arabulucu seçildiği soruları önemlidir. Savaşın yerinin Herodotos tarafından Medlerin Kızılırmak'a kadar tüm bölgeyi eline geçirdiği bilgisi aktarıldığ 1 için genelde Kızılırmak'ın doğusunda olduğu varsayılmaktadır. Güneydeki Kilikya ve Babil krallarının arabulucu seçilmesi de muhtemelen onlara daha yakın bir alanda bu savaşın gerçekleştiğini düşündürür (Berndt-Ersoz 2012, 32). Astronomik hesaplamalar güneş tutulmasının MÖ 28 May1s 584 tarihinde gerçekleştiğini ve tam olarak yaşandığı hattın ise Adana, Niğde ve Konya üzerinden geçtiğini göstermektedir (Fig. 6) (http://eclipse.gsfc.nasa.gov/SEsearch/SEsearchmap .php?Ecl=-05840528. 01.10.2016 erişim). 5 sene süren ve galibi olmayan bir savaşın hangi şartlarda ve tam olarak hangi alanda gerçekleşmiş olduğunu anlamak şu anki arkeolojik veriler 1ş1ğında mümkün olmamakla birlikte savaşın bitirilmesine neden olabilecek bir doğa olayının askerler tarafından oldukça etkili bir şekilde yaşanmış olması gerekliği kabul edilebilir. Ayrıca, Kilikya ile Babil krallıklarına da yakın bir konum arandığında Niğde, Göllüdağ civarı oldukça güçlü bir olasılık olarak gözükmektedir. Aşağıda detaylı bir şekilde değinileceği gibi Kerkenes ile benzer düzenleme ve sur sistemine sahip bir yerleşim olan Niğde Göllüdağ yerleşiminin çevresi bu savaşın en azından bittiği dönem için en uygun konum olarak önerilebilir.

Galibi olmadan biten savaşın sonunda Lydia kralı Alyattes'in kızı Aryenis ile Med kralı Kyaksares'in oğlu Astyages'in evliliği ile taçlandırılan barış antlaşmanın kapsamı oldukça ilgi çekicidir. Mantıksal olarak kaybetmediği bir savaşın sonunda bir taraf kendi kızını karşı taraf ile evlendiriyorsa bunun karşıllı̆ında antlaşmaya dahil edilen maddelerin ne olabileceği sorusu akla gelmektedir. (Huxley 1997, 9-11: Herodotos'un aslında çifte evlilik kastetmiş olabileceğine ilişkin önerisi çok gerçekçi gözükmemektedir. Alyattes ile ya da saraydan bir soyluyla evlendirilen 
Medli bir gelin ile ilgili Herodotos'un bilgi vermiş olması beklenirdi.) $\mathrm{Bu}$ antlaşma sonrasında Kızılırmak'ın Medler ve Lydialılar arasında sınır olarak kabul edilmiş olduğu düşüncesi (Huxley 1997, 11; Summers 2014, 48) de savaşın kaybedeninin Lydia olduğunu düşündürmektedir. Orta Anadolu'nun bereketli topraklarının ve Phryg izleri taşıyan pek çok yerleşiminin Lydialıların en güçlü olduğu dönemde üstelik de kaybetmedikleri bir savaş sonucunda Medlere birakılmış olması akla çok yakın gelmemektedir. Kimmerlerin aksine Medlerin Kızılırmak'ı aştıklarına dair herhangi bir bilgi bulunmamaktadır ve ayrıca Orta Anadolu çevresinde de Medlere atfedilebilecek herhangi bir kalıntı ya da buluntu bilinmemektedir. Herodotos'un aktarımları haricinde Medlerin Kızılırmak yayında etkin olabileceklerini gösteren bir veri olmayışı aslında bu bölgede Lydia etkisinin aranabileceği olasıllğını akla getirmektedir.

MÖ 585 yılındaki bu antlaşmadan sonra Lydialılar ve Medler arasında herhangi bir mücadeleden bahsedilmemiş olması antlaşmanın oldukça etkin olduğunu göstermektedir. Summers $(2014,48)$ tarafından bu alanda ortaya çıkan Pteria krallığının Medleri desteklediklerinin önerilmesi de kabul edilebilir gözükmemektedir. MÖ 590-585 arasındaki savaş haricinde Medlerle Lydialılar arasında herhangi bir mücadelenin bilinmeyişi ve özellikle de Kyros'un ilerleyişine değin Medlerin Kızılırmak civarında etkin olduklarına dair herhangi bir veri bulunmaması bu önerinin kabul edilmesini engellemektedir. Buna karşın her geçen gün yeni çalışmalar Kızılırmak yayındaki yerleşimlerin Phryg karakterini daha anlaşılır hale getirmektedir ve Lydia egemenliğinde geliştiğini bildiğimiz Phryg kültürünün izlerinin görülüyor oluşu Med egemenliğinden ziyade Lydia egemenliğinin bu alanda söz konusu olduğunu düşündürmektedir. Lydia ve Medler arasındaki evlilik antlaşmasına bağlı olarak daha önceden Lydia egemenliğinde olan K1zılırmak havzasının ve çevresindeki belirli bir bölgenin Lydialıların egemenliğinde kalmaya devam etmiş olması akla daha yakın bir açıklamadır. Elbette bu bölgedeki yerleşimlerde Lydia kültürel unsurlarının net olarak görülmeyişi bu olasılığın kesinleşmesini engellemekle birlikte Lydia egemenliğinde olduğu bilinen Karia gibi pek çok bölgede de Lydia kültürel unsurlarına ait veri bulunmamaktadır. Aşağıda değinileceği üzere, bu bölgedeki yerleşimlerde henüz Lydia unsurlarının bulunmamış ya da tespit edilememiş olabileceği de akılda tutulmalıdır.

Lydia'nın egemenlik sınırının tanımlanması ile ilgili olarak araştırmacıların büyük bölümü (Huxley 1997, 11; Summers 2014, 48) tarafindan Medler ve Lydialılar arasında Kızılırmak'ın bir sınır kabul edildiği şeklindeki Herodotos'un aktarımı kabul görmektedir. Ancak, Herodotos sadece bir yerde Halys'ün Med ve Lydia arasında sınır olduğunu net olarak belirtir.

I. 72: "Medlerin toprakları ile Lydialılarınkiler arasında sinır, aslında Halys ırmağıydı ki, bu ırmak Ermenistan dağlarından çıkar. Kilikya'dan geçer, Matienleri sağına, Phrygia'yı soluna alıp, bu iki ülke arasında akar; bu ülkeleri geçtikten sonra kuzeye doğrularak Kapadokya Suriyelileri ile sol klyıdaki Paphlagonia arasında sınır çizer. Demek ki Halys ırmă̆ı hemen hemen bütün Asya'yı bir kıyıdan öbürüne kesmiş olur, bir yanda Kıbris adasinin karşısina rastlayan kıyı, öbür yanda Karadeniz klyıları. Burası bir çeşit boyun noktasıdır ve ayağına çabuk bir adam bu yolu beş günde alabilir” (Ter. M. Ökmen).

Herodotos diğer bölümlerde de sınır ifadesini kullanmamakla birlikte egemenlik alanlarının belirleyicisi olarak Halys'ü göstermektedir. Medli Kyaksares ile ilgili olarak 1.103: “En büyük çarpışmanın ortasında, gün gece olduğu sırada Lydialıları yenen işte odur; bütün Yukarı Asya'yı birlikler halinde toparlayı, Halys ırmağına kadar hükmü altına alan odur" şeklinde aktarmaktadır (Türkçe çevirideki bir farklılığa dikkat etmek gerekir, her ne kadar daha önceki bölümlerde savaşın galibi olmadığı belirtilse de bu metindeki Lydialıları yenen ifadesi bir çeviri hatasıdır, nite- 
kim İngilizce çevirilerde bu kısım "This was the king who fought against the Lydians..." Lydial1lara karşı savaşan şeklinde çevrilmiştir (Ter. A. D. Godley). Alyattes ile ilgili olarak da Kroisos'u anlatırken I. 6: "Halys ırmağının beri yakasındaki ulusların tyranı olan Alyattes' in oğlu" ifadesini kullanmaktadır (Kyros'un ilerleyişi ile ilgili olarak aktardığı bilgide Türkçe metindeki I. 76: "Onu topraklarından atmak için yola çıkmadan önce Ionialılara elçiler göndermiş, Kroisos'a karşı ayaklandırmayı denemişti” cümlesindeki "onu topraklarından atmak için" ifadesi diğer çevirilerde sadece "yürüyüşüne başlamadan önce" şeklinde geçmektedir (Ter. A. D. Godley).

Araştırmacıların büyük bölümü bu aktarımların Halys yani Kızılırmak'ın Medler ve Lydialılar arasında sınır olduğuna kesin olarak işaret ettiğini kabul etse de R. Rollinger (2003a, 305313; 2008, 53) buna karşı çıkmaktadır. Herodotos'un Halys ile ilgili tanımlamalarına tüm metin içinde bakıldığında aslında coğrafi bilgisinde eksiklikler olduğu net olarak görülmektedir. Nehrin yerini tam olarak bilmese de o dönem mevcut olan haritalar üzerinden ya da kendisine aktarılan bilgiler ışığında Halys'ü doğu ile batıyı birbirinden ayıran bir sınır hattı olarak kabul etmiş olduğu anlaşılmaktadır. Bu nedenle Halys olarak aktarılan sınır hattının gerçekte nehrin hattı olmayabileceği ve neresi olduğunun sorgulanabilir bir durum olarak karşımıza çıktığı söylenebilir.

MÖ 420 civarında kitabını kaleme almış olan Herodotos'un Medlerle ilgili olarak da olasılıkla daha sonraki dönemlere ait bilgileri ideolojik yapılandırma ile birlikte sunmuş olabileceği düşünülmektedir. R. Rolinger (2003a, 290 vd.; 2008, 51-65; 2010, 63 vd.) Medlerin aslında bir imparatorluk haline gelmediği ve bir konfederasyon formunda olduğunu önermektedir. Yazılı kaynakların büyük çoğunluğunda kuzey Mezopotamya, Suriye ve Kilikya bölgelerinin Med değil Babil egemenliğinde olduğunun aktarılması ve özellikle de Urartuların MÖ VII. yüzyıl sonunda Medler tarafından değil MÖ 547 yılında Kyros tarafından yok edilmiş olabileceği bilgisi ışığında Herodotos'un aktarımları sorgulanmaktadır. Medlerin kısa dönemler halinde Orta ve Doğu Anadolu'da etkin olmalarına karşın kalıcı olarak alanı kontrol altında tutmadıkları önerilmektedir. Bu görüş diğer araştırmacılar tarafından da yinelenmiş hatta "Med İmparatorluğu" için "Hayalet Imparatorluk" terimi kullanılmıştır (Van De Mieroop 2011, 275; Khatchadourian 2016, 91-92). Medlerle ilgili bu tartışmaların kesin arkeolojik veriler bulunmaksızın sonuca ulaşması mümkün olmamakla birlikte, Anadolu'da Medlere atfedilebilecek buluntu veya kalıntıların olmayışının yanı sıra Herodotos haricinde Asur kaynaklarının da Medlerle ilgili oldukça kısıtlı bilgi veriyor olması araştırmacıların "Hayalet Imparatorluk" terimini kullanmalarını haklı göstermektedir. Bu durumda yukarda değindiğimiz gibi Kızılırmak'ın doğusunda kalıcı bir Med kontrolünün olmadığ 1 ve tam tersine bu bereketli alanların Lydia kontrolünde olabileceği düşünülebilir.

Herodotos'un Kerkenes'i ilgilendirebilecek en önemli aktarımı (I. 16) Alyattes'in Kimmerleri Asya'dan sürmüş olduğu bilgisi olmalıdır. Herodotos bu durum hakkında detaylı bilgi vermezken Polyainos (VII. 2. 1) Alyattes'in Kimmerlerin ordusuna büyük kızgın köpeklerle saldırarak yenmiş olduğuna dair bir hikaye aktarmaktadır. İskitler hakkında daha detaylı bilgi vermesine karşın Herodotos'un Kimmerler ilgili aktardıkları oldukça sınırlıdır. Kroisos'tan çok önce Kimmerlerin Ionia'ya saldırdıkları ancak bunun kentleri boyunduruk altına almayan çapulcu akını şeklinde olduğunu (I. 6) ve Ardys zamanında Kimmerlerin Asya'ya geldikleri ve Gyges zamanında akropol hariç Sardis'i ele geçirdikleri aktarılmaktadır (I. 15). Bu durum Lydia ile iyi ilişkiler kurmuş olan İskitlerin varlıklarını devam ettirmelerine karşın Kimmerlerin Alyattes sonrasında tarih sahnesinden silinmiş olmasıyla ilgili olmalıdır.

Herodotos'un (I. 26) aktardığına göre Kroisos'un iktidara çıktığında doğu ile değil de batıyla savaşmaya başlaması doğunun bu dönemde Lydia için güvenli olduğunu yani Alyattes döneminde güven altına alındığını göstermektedir. Kimmerleri yenerek Anadolu'dan kovan Alyattes, 
Medlere karşı da yenilmediği bir savaş sonrasında yapılan evlikle güçlendirilmiş bir antlaşma ile doğudan gelecek tehlikeleri engellemiş olduğu kabul edilebilir. Alyattes tarafindan alınan bu askeri başarıların Sardeis'ten bu kadar uzak bir alanda gerçekleştirilmiş olması dikkat çekici bir durumdur ve muhtemelen bölgede kurulan askeri garnizonlar sayesinde olmalıdır.

İlk olarak MÖ 715/714 yılında o zamanın en güçlü ordularından birine sahip olan Urartuları yendiği aktarılan Kimmerler'den sonraki 35 y1l boyunca metinlerde bahsedilmez. MÖ 678/677 yıllarında Asurlular tarafından Kapadokya'da yenilgiye uğratılmış oldukları aktarılan Kimmerlerin bu evrede muhtemelen büyük gücünü batıya yönlendirmiş oldukları bilinmektedir. Nitekim, MÖ 675 civarında dönemin bir diğer büyük gücü olan Phrygia’yı yıkmışlar, MÖ 660 civarında ise Lydia'ya saldırılara başlamışlardır. Bu evrede Asur kralına elçi gönderen Gyges'in tüm Lydia'yı çekirgeler gibi kaplamış olan Kimmerlere karşı yardım talep ettiği ve vergi vermeyi önerdiği aktarılır. Yardımın gidip gitmediği bilinmemekle birlikte Gyges'in bu evrede Kimmerleri yendiği düşünülmektedir. MÖ 644 yılında ise Lygdamis/Tugdame idaresindeki Kimmerler tekrar Lydia'ya saldırarak akropolis hariç Sardeis'i tahrip etmiş ve Gyges'i öldürmüştür. Daha sonra da Ionia ile Aeolis kentlerine saldırılar düzenlemişlerdir. MÖ 641 yılında Lygdamis Tabal'da hastalıktan dolayı ölmüştür ancak yerini alan oğlunun Asur üzerine saldırılarına devam ettiği bilinmektedir. MÖ 639 sonrası Akad metinlerinin politik tarih konusunda bilgi vermeyişi Kimmerlerle ilgili bilginin azalmasına yol açmıştır. MÖ 620 civarında İskit kralı Madyes ve MÖ VII. yüzyıl sonunda da Lydia kralı Alyattes'in Kimmerleri yenmiş oldukları bilinir. İskitler ile aynı kültürden oldukları bilinen Kimmerler ile ilgili daha sonraki dönemlere ait bilgi bulunmamaktadır (De Boer 2006, 63-65; Ivantchik 2010, 41-43).

100 yıldan fazla süre Anadolu'da kalan Kimmerlerin Phryg, Urartu ve Asur krallıklarının yok oluşunda rol oynadıkları ve Batı Anadolu kentlerini yağmaladıkları dikkate alındığında Lydia krallığın gelişim sürecindeki en önemli düşmanı olduğunu kabul etmek mümkündür. Gyges'in İon ve Kar askerlerini kiralamasına rağmen Kimmerlere karşı Asurluların yardımına başvurması tehdidin ve mücadelenin de büyüklüğünü göstermektedir. Gyges'in savaşta galip gelmesine rağmen ardılı Ardys döneminde Sardeis'in Kimmerlerce ele geçirilmiş olması mücadelenin devamlılığını ve Kimmerleri yenmek için kesin tedbirler alınması gerektiğini Alyattes'e göstermiş olmalıdır. Yukarıda değinildiği gibi İskitlerle kurulmuş olması muhtemel müttefiklik ilişkisi Alyattes'in aldığı tedbirlerden ilki olmalıdır. Bu noktada Gordion Küçük Höyük’teki Alyattes dönemi Lydia garnizonunun varlığ1 (Glendinning 1996, 111; Berndt-Ersoz 2006, 111; Rose 2012,16) çok önemli bir soruyu akla getirmektedir. Lydialılar ve Phrygialılar arasında geçen bir mücadele ya da savaş ile ilgili bir aktarım olmadığına için aralarında antlaşmalarla kurulmuş barışçıl ilişkiler bulunduğu kabul edildiği için Kimmerler tarafından yıkılan Phryg başkentindeki bu garnizonun o dönemdeki en önemli düşman olan Kimmerlere karşı kurulmuş olması en mantıklı açıklamadır. Askeri açıdan bakıldığında akınlar şeklinde saldıran Kimmerlere karşı ana kentlerde ya da yol güzergâhlarında kurulacak askeri yerleşim ya da garnizonların akınlardan korunmak için oldukça faydalı olacağı kabul edilebilir. Kızılırmak yayı içinde ve çevresinde bu dönemlere tarihlenen pek çok tahkimli yerleşim bulunmakla birlikte (Vergnaud 2012, 40-73) bunlardan Samsun Akalan, Yozgat Kerkenes ve Niğde Göllüdağ yerleşimleri genel düzenlemeleri ve özellikle de tahkimat sistemleri ile ortak özellikler göstermektedir (Vergnaud 2012, 172-176). Aşağıda detaylı değerlendirilecek olan bu benzerlikler, kuzey-güney doğrultusunda Anadolu'yu ikiye bölen dik bir hattı takip eden ve özellikle de ana yolları kontrol edebilecek konumda yerleştirilmiş bu üç yerleşimin (Fig. 6) Alyattes döneminde kurulmuş veya tahkim edilmiş askeri amaçlı yerleşimler olabileceğini akla getirmektedir. Lydia'dan bu kadar uzakta, ana yolları kontrol edecek stratejik pozisyonlardaki bu askeri yerleşimlerin Kimmer istilasını durdurabilecek kilit noktalar olarak katkı sağlayacağı kesindir. Bu varsayımı doğru kabul 
ettiğimizde Medler ile olan mücadelenin de sadece İskitler ile kurulan müttefiklikten dolayı değil de Lydia'nın sınırını oldukça doğuya ilerletmiş olması sebebiyle çıkmış olabileceği daha kabul edilebilir bir gerekçe olarak ortaya çıkmaktadır.

Kerkenes'in kuruluş tarihi ile aynı tarihlerde yürütülen Kimmer mücadeleleri için kurulmuş bu askeri yerleşim varsayımı yukarıda değinilen Lydia-Med savaşının 5 yıl boyunca sürmesini de sağlamış olabilir. Medlerin batıya doğru ilerlediklerine ilişkin elimizde hiçbir veri bulunmadığ 1 için Lydialıların doğuya ilerlemiş olması ve anakentten bu kadar uzakta savaşmasını da Göllüdağ ve Kerkenes yerleşimlerindeki ikmal olanaklarıyla çözmüş olmaları akla yakın gelmektedir. Bir diğer önemli detay da yukarda değinilen Lydia'yı yenilmiş gibi algılamamıza yol açan antlaşma şartlarıyla ilgilidir. Galibi olmayan bir savaş sonucunda kendi kızını Kyaksares'in oğlu ile evlendiren Alyattes'in akrabalık ilişkisi karşılığında bu yerleşimleri elinde tuttuğu ve birbirlerine karşı saldırmayacaklarının garantisini vermiş olmaları daha mantıklı bir açıklama olarak gözükmektedir. Herodotos tarafından Kızılırmak'ın Medler ve Lydialılar arasında sınır olarak kabul edilmiş olduğu aktarımı da bu varsayım ile anlam kazanır. Samsun, Yozgat ve Niğde'deki bu üç yerleşimin kuzey güney doğrultusunda uzanan Anadolu'yu ikiye böler şekildeki dik bir hattaki konumu Herodotos'un Halys ile ilgili olarak Anadolu'yu ikiye böldüğü şeklindeki aktarımı ile uyum göstermektedir. Kentin kurulmasından yaklaşık 200 yıl sonra kaleme alınmış ve yazarı tarafından görülmemiş alanlarda geçen mücadeleler ile ilgili aktarımlarda bazı detayların atlanılmış ya da karıştııılmış olabileceği de bu kapsamda kabul edilebilir gözükmektedir.

MÖ 585 yılındaki barış antlaşması sonrasında Herodotos tarafından Medler ve Lydialılar arasında herhangi bir mücadele anlatılmamaktadır. Kimmerlerin Asya'dan sürülmesini sağlayan ve Medlerle uzun süreli bir mücadele sonrasında savaşı kazanmasa da akrabalık ilişkisi ile taçlandırılmış bir barış antlaşması ile doğu sınırını güvenceye alan Lydia'nın güçlenmeye devam ettiği ve yüzünü batıya döndüğü görülür. Bu 40 yıllık barış süreci ancak Astyages'in Kyros tarafından devrilmesi sonrasında bozularak Lydia ve Pers mücadelesi başlamıştır. Herodotos (I. 75) bu savaşın sebebi olarak Kroisos'un Kyros'a Astyages'i devirmesi sebebiyle kızmasını gösterir, ancak gerçek neden Lydia'nın doğu sınırının tehlikeye girmiş olması olmalıdır. Bu noktada Perslerin nereye kadar ilerlemiş olabilecekleri ya da mevcut Lydia garnizonlarını ele geçirip geçirmedikleri ile ilgili bir bilgi bulunmamaktadır. Medlerin devrilmesi sonucunda 40 yıldır devam eden barış antlaşmasının iptal olması Kroisos'u doğu sınırını Kyros'a karşı korumak zorunda bırakmış olmalıdır. Herodotos (I. 75) tarafından aktarılan Kroisos'un Perslere savaş açmalı mıyım diyerek kâhinlere danışması hikâyesi de bu anlamda daha mantıklı bir görünüm kazanır. Kyros'un Lydia'ya saldırıp saldırmayacağından emin olmayan Kroisos'un olayların ilerleyişini beklemek ile Alyattes döneminde kurulmuş doğudaki askeri yerleşimlerini geri almak ya da güçlendirmek üzere Kızılırmak'1 aşmak gibi iki seçeneği bulunduğu varsayılabilir. Böylece sadece Kyros'a kızdığı için değil düşmanın saldırmasını beklemesinin mi, yoksa savunma amaçlı karşı harekete geçmesinin mi daha doğru bir hareket olacağı konusunda kahinlere danışmış olması akla daha yakın bir açıklama olarak kabul edilebilir.

Herodotos'un (I. 75) Kroisos'un ırmağı geçerken mevcut köprüleri kullanmış olabileceğini aktarması bu bölgenin bilindiğini, yolların ve köprülerin kullanımda olduğunu düşündürmektedir Halys'ü geçmesi ile ilgili ırmağın ikiye bölündüğünü içeren bir başka versiyonu da aktarmış olması ise bölgeyle ve Halys ile ilgili yeterli bilgisinin olmadığını destekleyen bir durumdur. Kroisos'un Kızılırmak'ı aşarak doğrudan Kapadokya'daki Pteria bölgesine geldiğinin aktarılması da bu bölgenin Kroisos tarafindan bilindiğini göstermektedir. Yukarıda değindiğimiz gibi Herodotos'un aktarımları Pteria'nın bir kent olduğu ve Kroisos'un bu kenti yıktığı şeklinde an- 
laşılmamaktadır. Bununla birlikte Herodotos'un (I. 76) “... Orada konakladı ve Suriyelilerin yurtlarını yağma etti; ülkenin başkentini aldı ve halkını köleleştirdi; çevrede köy, kasaba ne varsa hepsini aldı ve kendisine hiçbir zararları dokunmamış olan Suriyelileri göç etmek zorunda bıraktı" (Ter. M. Ökmen) şeklindeki aktarımı ilgi çekicidir. Kerkenes'te yürütülen çalışmalar sonucunda kentin güç kullanılarak ele geçirildiğine dair net bir iz bulunmamasına rağmen tamamen yağmalandığı ve belirli bölümlerde eş zamanlı olabilecek yangınlar görüldüğünün tespit edilmesi Summers $(2014,48)$ tarafindan önerilen kentin Herodotos'un bahsettiği Pterialıların kenti olduğu ve Kroisos tarafından tahrip edildiği varsayımı ile uyuşmamaktadır. Büyük bir orduyla bölgeye gelmiş olan Kroisos'un 7,5 km uzunluğunda surlara sahip oldukça korunaklı ve stratejik bir konumda bulunan Kerkenes yerleşimini ele geçirmesi arkeolojik olarak daha fazla kanıt bırakacak bir durum olmalıdır. Büyük bir olasılıkla, Kroisos Pteria bölgesine geldiğinde barış dönemiyle bağlantılı olarak asker sayısı daha önceden azaltılmış olan mevcut garnizonu güçlendirmek amacıyla çevredeki küçük yerleşimlere saldırmış ve Perslerle savaş sırasında s1kıntı yaratabilecek toplulukları bölgeden uzaklaştırmış olmalıdır. Lydia egemenliği ve olası vergilerinden şikayet eden bölge halkının daha önceki evrede Kerkenes'teki askeri yerleşime sıkıntı yaratmış olmaları ihtimali de akla gelmektedir ve Kroisos'un agresif hareketlerini ve Pterialıların kentini alarak halkını köleleştirmesini açıklayan bir durum olabilir.

Kyros ve Kroisos'un savaşı ile ilgili olarak Herodotos'un anlattıklarına baktığımızda yine ilginç noktalar göze çarpmaktadır; “(I.76): Sonunda Kyros, Kroisos'a ulaştı ve geldi Pteria'da onun karşısında konakladı, işe başladılar ve birbirlerinin boyunu ölçtüler. Büyük savaş oldu, iki yandan da çok adam düştü; sonunda gece ayırdı onlar birbirlerinden, yenen yenilen belli olmadl. (I. 77) Bu ilk çarpışma böyle bitti. - Kroisos kendi kendine kızlyordu, çünkü sayıca azdı (Zira savaşa sürdüğü asker sayısı Kyros'unkinden çok daha azdı). Bu bakımdan altta kaldığına hükmederek ve ertesi gün Kyros'un kendisine yeniden saldırmadığını görerek Sardes yolunu tuttu; ..... sonucu iyice belli olmamış bir savaşın arkasından Kyros'un Sardes'e kadar gelmeyi akıl edebileceğini hatırina bile getirmiyordu".

Öncelikle akla gelen ilk soru Herodotos'un aktarımına göre savaşın sadece bir gün sürmüş olması ve Kyros'un ertesi gün geri çekilen Lydia ordusunu fark etmemiş olmasıdır. Antik yazarlardan Polyainos (VII. 8. 1-2) bu konuda farklı bilgi vermektedir. Kapadokya'da Kyros'a yenilen Kroisos'un adamlarına çok miktarda odun toplattığını ve ordusunu geceleyin geri çektikten sonra geride bıraktığı hızlı süvarilere sabah odunları yaktırdığını ve bu ateş nedeniyle Kyros'un orduyu takip edemediğini aktarır. Elbette bu aktarımların tamamen doğru olduğunu kabul etmek mümkün olmamakla birlikte Kerkenes yerleşiminin savaştaki rolü kabul edildiğinde anlamlı bir varsayım ileri sürülebilmektedir. Kroisos, Kerkenes yerleşimin yer aldığı Pteria bölgesine gelip çevredeki asileri cezalandırdıktan sonra Kerkenes askeri garnizonunu güçlendirmiş olmalıdır. Böylece, olasılıkla aşağıdaki düzlüklerde yapılan savaş sonrasında tekrar kente girmiş olmalıdır. Herodotos'un aktardığına göre Kyros'un ertesi gün saldırmamış olması da ordunun kentin içinde yer alması ile alakalı olabilir. Kyros'un tekrar düzlükte savaşmayı beklediği kabul edilirse kentin birbirinden uzak ve aşağılardan görülmeyecek 7 kapısından birinden Kroisos'un ordusunu geri çekmiş olması çok şaşırtıcı bir durum yaratmamaktadır. Kerkenes'in boyutları göz önüne alındığında ve özellikle de Gözbaba Kapısı gibi kentin dışından hiç takip edilemeyecek durumdaki yollara açılan kapılarının varlığı ordunun görünmeden hatta kaçma manevraları bile yapmasına gerek kalmadan sağlam bir şekilde geri çekilmesine katkı sağlamış olmalıdır.

G. Summers (2014, 48-49) tarafindan Kerkenes'in Medleri desteklediği için cezalandırıldığ ya da Sardeis'e döndükten sonra Kyros'un kış aylarını Kerkenes'te geçirmesini engellemek amacıyla Kroisos tarafından yakıldığı önerilmiştir. Herodotos (I. 88-89) Sardeis'in düşüşü son- 
rasında Kyros'un ordusunun kenti yağma edişi sırasında Kroisos'un Kyros'a kendi kentini neden yağma ediyorsun diye sorduktan sonra yağmanın durduğunu anlatır. Kerkenes eğer Kroisos tarafından ele geçirilmiş olsaydı, Herodotos'un aktarımı doğrultusunda Kroisos'un kendi kentini yağmalayıp tahrip etmeyeceği varsayılabilir. Bu öneri Polyainos'un aktarımıyla birlikte düşünüldüğünde farklı bir şekilde kabul edilebilir gözükmektedir. Kerkenes'te araştırılan bölümlerde kente yönelik bir saldırıya ait herhangi bir iz bulunmamasına rağmen birbirinden bağımsız noktalarda yangınların izlerinin tespit edilmiş olması, özellikle Polyainos'un aktardığı odun yakarak Kyros'un takibini engellediği şeklindeki aktarımı ile ilişkilendirilebilir. Kroisos'un ordusunu salimen geri çekene kadar kentte bulunduğu izlenimini verdiği ve belirli bir süre sonra da kentte bıraktığı az sayıda süvari tarafindan kentte belirli noktaların yakılarak kentin kullanılmaz hale getirilmiş olduğu düşüncesi pek çok açıdan mantıklı bir açıklama olarak gözükmektedir. Öncelikle geri çekilen bir orduyu hareketli başka bir ordunun özellikle de Kroisos'un peşinden Sardeis'e çok hızlı ulaşan Kyros'un ordusunun takip etmemiş olması, ancak ordunun geri çekildiğinin fark edilmemesi ile açıklanabilir. Kroisos'un Kerkenes'i savaş sırasında garnizon olarak kullandığ 1 ve savaşın düzlükte gerçekleşmiş olduğu varsayımı ise Herodotos (I. 80-81) tarafından aktarılan Kyros'un Sardeis'e ulaştığında düzlükte gerçekleşen ve yenilmek üzere olan Lydialıların surların içine çekildiği savaşla karşılaştırılabilir. Sardeis'in bu evrede kuşatılmış olmasına rağmen Kerkenes'in neden kuşatılmadığı sorusunun cevabı da Kerkenes'i kuşatmayan ve Kroisos'un ordusunu düzlükte bekleyen Kyros'un tekrar aynı şekilde Kroisos kaçmasın diye Sardeis'i kuşatmış olduğu şeklinde verilebilir. Bu noktada Kyros'un beklenilenin aksine hızlı bir şekilde Sardeis'e yürümüş olması da her ne kadar antik yazarlar tarafindan aktarılmasa da Kroisos'un ordusunu fark ettirmeden geri çekmesine kızan Kyros'un aldatılmış hissederek öç almak istemesi ile alakalı olabilir. Yerleşimde savaş izlerinin görülemiyor oluşu ve kazılan alanlarda yağmalanmış izlenimi verecek şekilde buluntunun çok az ele geçiyor oluşu da bu kapsamda anlam bulmaktadır. Lydia krallığına ait olan Kerkenes garnizonu ordunun çekilmesi sırasında taşınabilir eşyaları, köle ve aileleri ile birlikte topluca boşaltıldığı için buluntu ele geçmemektedir ve Lydialılar tarafından yakıldığ

Antik kaynakların verdiği bilgiler 1şı̆̆ında arkeolojik veriler değerlendirildiğinde Kerkenes'in Pteria bölgesinde yer alan bir Lydia garnizonu olabileceği olasılığı çok güçlü gözükmektedir. Kentin aslında bir isminin olmadığı kanat yani sınır hattı anlamına gelen Pteria kelimesinin Lydialıların doğu sınır hattını belirlemek için kullanılmış olabileceği ve Herodotos'un başkalarından duyduğu ya da haritada gördüğü bu kelimenin ifade ettiği anlamı tam olarak bilmeden kullanmış olabileceği olasıdır. Uzunca bir süredir araştırılıyor oluşuna karşın çok az kazı yapılmasına bağlı olarak arkeolojik verilerin sınırlı olduğu Kerkenes yerleşiminin bir Lydia garnizonu olabileceğini önermek elbette çok kolay kabul edilebilecek bir öneri değildir. İlk araştırmalarda Med kenti olduğu, daha sonra Phryg buluntuları ele geçmesiyle Phryg kültüründe bir topluluk tarafindan kurulan bağımsız bir krallığa ait olduğu önerilen kentin sakinlerinin kimler olduğu ve özellikle de ele geçen kültür kalıntılarının kentin kimliğini tanımlamak için yeterli olup olmadığ 1 en temel sorulardan birisidir. R. Rollinger tarafından Kerkenes'in bir Med kenti olamayacağ işlenen yayınında Kerkenes' in yerel bir kurulum hatta Lydia tarafından kurulmuş olma ihtimalinin Med kenti olmasından daha yüksek olduğu vurgulanmıştır (Rollinger 2003b, 326). B. Vergnaud $(2012,298)$ tarafından Demir Çağı sur sistemleri üzerine yapılan çalışmada da Kerkenes'te Lydia buluntusu ele geçmediği için Lydia kuruluşu denemeyeceği vurgulanmıştır.

\section{Arkeolojik Veriler}

Kentte ele geçen yayınlanmış buluntular büyük oranda Phryg kültürüne işaret etmekle birlikte mevcut buluntuların o kentte yaşayanlara $\mathrm{m} 1$ yoksa kentin kimin egemenliğinde olduğuna $\mathrm{m} 1$ 
işaret ettiği sorusu irdelenmelidir. Bu bağlamda dikkate almamız gereken ilk nokta Batı Anadolu'ya yaklaşık 150 yıl boyunca hükmetmiş Lydia Krallığının izlerinin hükmettiği kesin olarak bilinen bölgelerde bile ne kadar sınırlı olduğu gerçeğidir. Herodotos (I. 28) Batı Anadolu'daki tüm halkların Lydia'ya boyun eğmiş olduğunu aktarmasına rağmen arkeolojik verilere baktığımızda Lydia kültürüne ait izler neredeyse yok denecek kadar azdır. Her geçen gün yeni araştırmalar sonucunda bu sinırlı bilgilerimizin arttığı görülmekle birlikte Lydia Krallığı Sardeis'te büyüyerek gelişmiş ve Karia ya da Phrygia gibi bölgelerden çok iyi bildiğimiz üzere yerel halkın kültürel kimliğinin korunarak idari anlamda hakimiyet kurulan bir yaklaşıma sahip olmuştur. Lydia'nın bu durumu yeni kurulacak bir kente özellikle de askeri bir yerleşime gönderilecek ordu mensuplarının sadece Lydlerden oluşamayacağını ve egemenliği altındaki halklardan devşirilmiş karışık bir nüfus olduğuna işaret etmektedir. Bu kapsamda Kerkenes’teki mevcut verilerin büyük çoğunluğunun Phryg kültürüne işaret etmesi kentin Phryg ya da Phryg kültüründeki insanlar tarafından kurulmuş olduğunu değil sadece kentin belirli bir bölümünde Phryg kökenli insanların ikamet etmiş olduğunu net olarak göstermektedir.

Lydia ve Phrygia ilişkilerine baktığımızda herhangi bir münakaşanın antik kaynaklarda betimlenmeyişi aralarındaki ilişkinin oldukça barışçıl olduğuna işaret etmektedir (Berndt-Ersoz 2012, 32) ve Kimmerlerin Phrygia'y1 yıkması sonrasında Kimmerleri Asya'dan süren önemli güç Lydia'nın bölgedeki egemenliğini kalan Phryg soyluları ile yapılan antlaşmalarla kurmuş olması büyük bir olasılık olarak kabul edilebilir (Vergnaud 2012, 286). MÖ VI. yüzyılın ilk yarısı boyunca Lydia etkisi Gordion'da arkeolojik olarak belgelenmiştir. Elektron sikkelerin MÖ 600 itibarıyla kullanılmaya başlanmasının yanı sıra parlak renkli geometrik bezekli ya da figürlü mimari terrakottaların kullanılmaya başlanmasının da Lydia etkisinin bir sonucu olduğu düşünülmektedir. Gordion Küçük Höyükte ele geçen Lydia seramikleri de muhtemelen Alyattes döneminde kurulmuş olan Lydia garnizonu ile ilişkilendirilmektedir ve Küçük Höyük’te tespit edilen yangın ya da tahrip tabakasında ele geçen Lydia ve Attik seramikleri ile kalıntılar Perslerin 546 yılındaki ilerleyişleri sırasında Lydia garnizonunu tahrip ettikleri şeklinde yorumlanmıştır (Glendinning 1996, 111-116; Berndt-Ersoz 2006, 111; Rose 2012, 16). Nitekim Orta Phryg dönemi de iki evreye ayrılmış ve MÖ 600-550 arası Lydia egemenliğindeki dönemi ifade etmek için Orta Phryg II evresi olarak tanımlanmaktadır (Berndt-Ersoz 2006, XXI, 90). Anıtsal kaya cephe mimarisi uygulamalarının Phrygia'da ilk olarak MÖ VI. yüzyılın ilk yarısında Lydia egemenliği altında iken üretilmeye başlamış olmasının Lydia egemenliği ile birlikte Phryg kült alışkanlıklarının da değişmeye başladığına işaret ettiği düşünülmektedir. Ayrıca, Phryglerin politik ve askeri olarak güçlerini kaybetmiş oldukları bir dönemde kendi kültürlerini daha önceden olmadığ 1 kadar anıtsal boyutlarda ifade etmeye başlamış olabilecekleri önerilmiştir (BerndtErsoz 2006, 129-130, 211). Susanne Berndt-Ersoz tarafindan Phryg kaya anıtları üzerinde yap1lan çalışmadaki bir öneri Lydia ve Phryg ilişkisinin boyutunu anlamamıza katkı sağlayabilir. Midas anıtındaki yazıtta Midas isminin yanı sıra Ates ismi geçmektedir ve bu ismin Kroisos'un oğlu Atys olabileceği önerilmiştir. Phrygia hakimi olan Lydia Kralı Kroisos'un oğlu Atys'ü Phrygia Ana Tanrıça Kültünün başrahibi olarak atamış olabileceği ve Midas anıtının da Phyrg kültürüne ve özellikle Midas’a saygı gösteren bir Lydia adağı olabileceği önerilmiştir. Lydialıların Phrygia'nın kontrolünü ele geçirmesinden sonra yüksek din ofislerinin de kontrolünü ele aldıklarının kabul edilebileceği ve özellikle Lydialıların dinsel merkezlere zengin adaklarda bulundukları bilindiği için Midas anıtının ve yakınındaki stoanın Lydia etkisinde adaklar olarak değerlendirilebileceği önerilmiştir. Lydia etkisinde yapılmış çok sayıda anıt barındıran Midas kentinde çok fazla araştırma yapılmamış olmakla birlikte MÖ VI. yüzyılın ilk yarısında bir refah dönemi yaşadığını gösterecek buluntular mevcuttur. Pers idaresinde de Lydia-Phryg kültürünün yaşamaya devam ettiği ve Kroisos'un genç yaşta ölen oğlu Atys/Ates'in ölüm yıldönümü kut- 
lamalarının daha sonraki dönemde Attis kültünü ortaya çıkarmış olabileceği önerilmektedir (Berndt-Ersoz 2006, 129-130, 166, 177-178; Berndt-Ersoz 2009, 16-17. Attis'in ilk olarak MÖ IV. yüzyılda görülmeye başladığı ve erken Phryg kültüründe karşımıza çıkan Ata adlı erkek tanrıdan farklı olduğu kabul edilmektedir.).

Lydia ve Phrygia ilişkileri hakkında antik kaynakların yeterli bilgi sunmayışları elbette bu dönemi anlamamızda sıkıntılar yaratmaktadır. Bununla birlikte Batı Anadolu'daki tüm bölgelerin hakimiyetini ele geçiren Lydia krallığının ordusunun egemenliği altındaki Kar ve İon gibi halklardan oluştuğunun bilinmesi Phryg halkının da doğal olarak Lydia ordusunda görev yapmış olduklarının kabul edilmesini sağlamaktadır.

Kentin buluntularına değinmeden önce vurgulanması gereken en önemli Phryg karakteristiği tümülüslerin varlığıdır (Summers 2013b, 225). Schmidt $(1929,250 \mathrm{vd})$ tarafından yapılan kazı çalışmalarında kentin $2 \mathrm{~km}$ batısındaki tepelerde 69 adet tümülüsten oluşan bir dizi bulunduğu belirtilmiş ve kazılan örneklerde Phryg tarzında buluntular ele geçmesine karşın herhangi bir mezar yapısı tespit edilmemiştir. Daha sonraki çalışmalarda ise Kerkenes çevresinde 100'den fazla tümülüs bulunduğu belirtilmekle birlikte herhangi bir çalışma gerçekleştirilmemiştir (Summers 2012a, 167). Bugün bölgeye gelenlerin kolaylıkla fark edeceği üzere kentin özellikle güneyindeki tepe sırtlarında ve aşağıdaki düzlüklerde bazıları höyük olarak tanımlanması gereken çok sayıda tümülüs gözle görülebilir durumdadır. Yöre halkı tarafından halen yoğun bir şekilde kazılarak tahrip edilen bu tümülüslerden Schmidt (1929, 250-255) tarafindan kentin güneyindeki tepelerde kazılan örneklerde tarihleyici bir unsur veya mezar yapısı tespit edilememiştir.

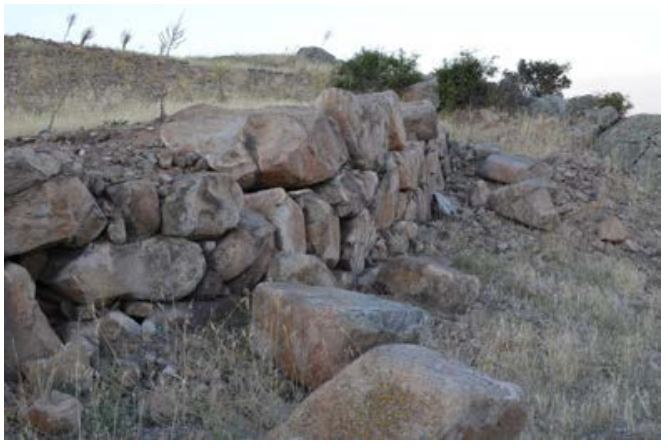

Fig. 7. Tümülüs krepis duvarı olarak tanımlanabilecek duvar kalıntısı

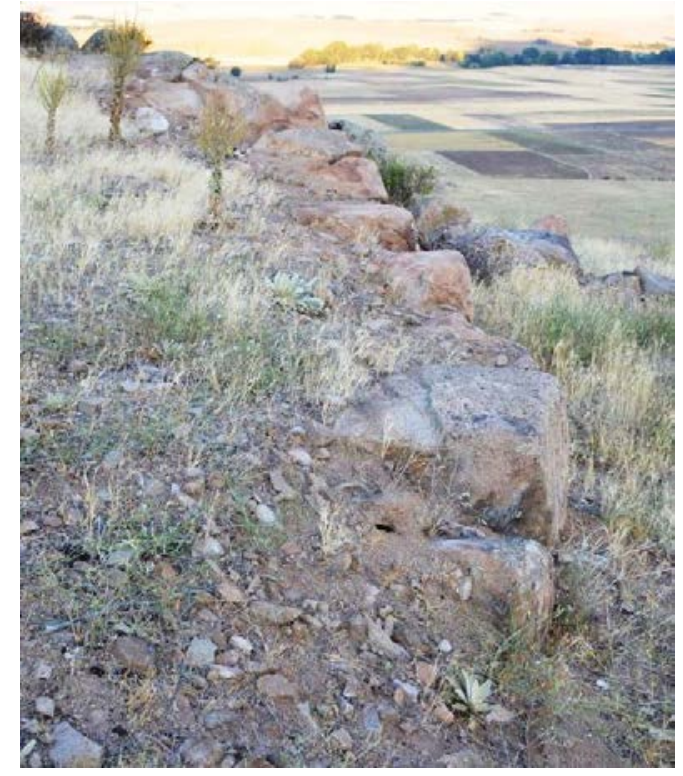

Fig. 8. Tümülüs krepis duvarı olarak tanımlanabilecek duvar kalıntısı

Kent çevresindeki bu tümülüslerin haricinde kentin içinde ve yakın çevresinde henüz detaylı çalışılmamış olan çok sayıda küçük tümülüs bulunduğu ve toplanmış taşlarla yapılmış içlerinde sanduka mezarlar bulunan, değişik ölçülerdeki tümülüslerin kent terk edildikten sonraki geç dönemlere ait olduklarının tahmin edildiği belirtilmiştir (Schmidt 1929, 237-240; Summers 1996, 218-224; 2008, 68-71). Mevcut veriler 1şı̆̆ında bölgedeki tüm erken dönem tümülüslerin Phryg karakteristiği taşımış olduğu varsayılmakla birlikte Doğu Kapı'nın 500 m doğusunda tepenin karayolu ile birleştiği noktada oldukça tahrip edilmiş bir tümülüs tarafımızca tespit edilmiştir. Yoğun kaçak kazı ve tahribatın yaşandığı tepenin en dikkat çekici kısmı yuvarlak formda tepeyi çevreleyen duvar hatııın görülebilir oluşudur (Fig. 7-8). Alanda detaylı çalışma firsatı bulunmamıştır, ancak genel görünüm ve düzenlemesiyle Lydia tipi krepisli bir tümülüs olabileceği

büyük bir olasılık olarak değerlendirilmiştir (Klazomenai'da tespit edilen çok sayıda Lydia tipi 
tümülüs örneğinden özellikle Nalbanttepe tümülüs 4 krepis duvarı ile karşılaştırılabilir. Hürmüzlü 2005, 47, Fig.7; Ersoy 2007, 175). Bu alan ilerde yapılacak çalışmalarda öncelik verilmesi gereken bir alan olmalıdır. Kerkenes çevresinde bu tip Lydia tümülüslerinin bulunup bulunmadığı ile ilgili detaylı çalışma henüz yapılmamış olmakla birlikte daha önceki yayınlarda bahsedilen eğimli destek duvarıyla kaplanmış yamaçlara sahip Tilkigediği Tepe ve Gözbaba Tepe bu kapsamda ilgi çekmektedir. Kerkenes'in $3 \mathrm{~km}$ kuzeydoğusundaki bir sırt üzerinde yer alan Tilkigediği Tepenin orijinalinde bir tümülüs olabileceği ve sonradan Akhamenid devrinde bir gözetleme kulesi işlev görmüş olduğu önerilmiştir. Tespit edilen az sayıdaki seramik buluntusu kesin bir tarih vermemesine karşın tepenin kuzeybatı yanında görülen ve glacis olarak tanımlanan taş kaplamanın varlığı ve oldukça geniş bir görüş alanına sahip olması gözetleme kulesi olarak tanımlanmasına yol açmıştır. Summers (1995, 43 vd.; 2001, 39 vd.) tarafından Tilkigediği Tepenin en yakın benzerleri olarak Gözbaba ve Keykavus kale olarak tanımlanan akropolis gösterilmiştir (Vergnaud 2012, 40: Summers tarafından Akhamenid döneme ait olduğu önerilen Keykavus Kale K. Strobel tarafından Yozgat'taki Çeşka Kale ile karşıllaştırılarak MÖ 800 civarına tarihlendirilmiş olmakla birlikte B. Vergnaud tarafından her iki tarihlendirmenin de net olarak kabul edilemeyeceği belirtilmiştir). Duvar tekniklerinin Kerkenes sur duvarına göre daha küçük taşlardan ve özensiz oluşturulmasıyla farklı olması ve Tilkigediği Tepe'de Akhamenid dönem olarak tanımlanan seramiklerin ele geçmesi sebebiyle bu üç örneğin Kerkenes'ten sonraki döneme ait gözetleme kuleleri olabileceği önerilmiştir. Kerkenes'in $4 \mathrm{~km}$ güneybatısında Kerkenes dağın en yüksek noktasında yer alan Gözbaba, Schmidt (1929, 225, Fig.5) tarafindan yapılan çalışmalarda kent içindekine benzeyen bir kale olarak tanımlanmış ancak yakın zamanda yapılan kaçak kazı çukurlarında görülen detaylar sayesinde bir tümülüs olduğu anlaşılmışır (Summers 1995, 53; 2013a, 148). Keykavus kaledeki verinin çok net olmadığ 1 görülmekle birlikte hem Gözbaba hem de Tilkigediği tepe için yapılan öneriler çok ikna edici gözükmemektedir. Her ne kadar spekülatif bir yaklaşım olarak gözükse de tarafımızca glacis olarak tanımlanan bu destek duvarlarının Lydia tümülüslerinde gördügümüz krepis duvarlarının yerel uyarlamaları olabileceği olası görülmektedir. Aşağıda değinileceği üzere Kerkenes sur duvarlarında görülen eğimli destek duvarı surun bir bölümü iken bu örneklerde sadece toprağın kaymasını engellemek üzere kullanılmış kaplama taşları şeklinde bir düzenleme söz konusudur. Bu nedenle mezar sahipleri tarafından işlevi tümülüs toprağını bir arada tutmak olan Lydia tarzında krepis duvarının yerel bir uygulaması olarak bu düzenlemenin yaptırılmış olması, her ne kadar kesin olarak tanımlanamasa akılda tutulması gereken bir öneri olarak gözükmektedir.

Kentin tanımlanmasında önemli rol oynayacak bir unsur olmasına rağmen tümülüslerin ve mezar yapılarının bugüne değin detaylı bir çalışma konusu yapılmamış olması Kerkenes için önemli eksiklerden birisidir. İlerde yapılacak çalışmalar mezar tipleri, tarihleri ve özellikle de kısa süreli bir yaşam süren Kerkenes yerleşimi çevresindeki tümülüs mezar sayısının neden bu kadar çok olduğu ve hepsinin yerleşimle bağlantılı olup olmadığg gibi sorulara cevap verebilecektir.

Yukarıda değinildiği gibi, Saray kompleksi ve Kapadokya Kapısı'nda yürütülen kısmi kazılar Phryg kültürünü yansıtan buluntular açığa çıkartılmasını sağlamıştır. Eski Phryg dilinde yazıtlar ve grafitiler, bir tanesi basamaklı bir anıt biçiminde düzenlenmiş Phryg tipinde yarı-ikonik kült stelleri, megaron formda iki odalı beşik çatılı yapılar ve heykeltıraşlık eserleri Phryg kültürünü yansıtan unsurlardır ve kentin Phryg kültüründe insanlar tarafından kurulduğu önerisinin ortaya atılmasını sağlamıştır. Bununla birlikte bu kültürel verilerin içinde yaşayanların bir kısmının mı yoksa tamamının mı kimliğini yansıttığı ve daha da önemlisi bu kimliğin idari yapıyla bağlantısı sorgulanmalıdır. Bunlara cevap aranırken de Lydia kültürünün Pers idaresi altında yaşamaya devam ettiği ve özellikle de Phryg kültürünün Roma Dönemi içlerine kadar karakteristiklerini 
korumuş olduğu örnekleri akılda tutulmalıdır.

Bu noktada mevcut buluntularda dikkate değer bazı noktalar tespit edilebilmektedir. Örneğin, Kerkenes'te Saray Kompleksi giriş kapısı civarında ele geçen heykel oldukça dikkat çekicidir (Draycott et al. 2008, 10-21, Pls.12-26). Yakın Doğu, Phryg ve Batı Anadolu unsurlarını içinde barındıran heykelin Anadolu karakteristiğini taşıdığ özellikle vurgulanmıştır.

Cinsiyeti konusunda çok emin olunmamakla birlikte büyük olasılıkla erkek olduğu düşünülmektedir ve sakalın olmayışının da genç birinin betimlendiğine işaret ettiği önerilmiştir. Heykelin bir idareciyi mi, yoksa bir tanrıy mı simgelediği ise bilinmemektedir. Araştırmacılar tarafından Ksenophon tarafından bahsedilen Kapadokya kralı olabileceği olasılığı önerilmiş bu figürün Phryg pantheon'undaki Lydia etkisi düşünüldüğünde Ates olabileceği de akla gelmektedir. Berndt-Ersoz (2006, 129-130, 166, 177-178; 2009, 16-17) tarafindan Kroisos'un oğlu Başrahip Ates'in daha sonradan Attis'e dönüşmüş olduğu önerisi heykelin tanımlanması için akla çok daha uygun gelmektedir. Heykel ile aynı alanda ele geçmiş bir aslan heykeli parçası da bir diğer dikkat çekici buluntudur (Draycott et al. 2008, 21-23, P1.27). Aslan figürü tüm çağlarda en yaygın betimlenen figürlerden birisi olmakla birlikte teknik açıdan Yakın Doğu örneklerinden farklılık gösteren örnekteki şevron bezemesi Akalan ve Pazarlı terrakotaları ve Gordion'da ele geçen seramikler ile kıyaslanmaktadır. Yol kenarında konumlanması ise Yakın Doğu'dan ziyade Batı Anadolu ve özellikle Lydia uygulamalarıyla karşılaştırılabilmektedir. Bu heykellerin yakınında ele geçmiş olan kenarlarında bolsterler bulunan tabla (Draycott et al. 2008, 63-64, Pls. 62-64) istisnai bir örnektir ve Batı Anadolu' daki İon başlık örnekleriyle kıyaslanabilir. Tüm parçalar bir araya getirildiğinde, ortasında grifon kabartmaları, çevresinde Phryg yazıtları ve üstte bolsterli bir tabla üzerinde duran Tata tarafından adanmış erkek heykeli olarak tanımlanmaktadır (Draycott et al. 2008, Pl. 66). Şu an için her ne kadar kesin karşılaştırılabilir örnekleri bilinmese de Lydia idaresindeki Phrygler tarafindan Kroisos'un oğlu başrahip Ates'i betimleyen bir eser olarak tanımlanması oldukça güçlü bir olasılık olarak önerilebilir.

Ele geçen bir diğer heykel ise Kapadokya Kapısı çalışmalarında 2011 yılında bulunmuştur. Üzerinde tamamen parçalanmış kireçtaşı bir heykel taşıyan antithetik sphenks kabartmalı kaide henüz detaylı yayınlanmamıştır (Summers 2011, 6, Figs. 12-13; 2013b, 227, Figs. 5a-b). Bununla birlikte, resimlerden görüldüğü kadarıyla hem sphenks figürlerindeki hem de heykele ait parçalardaki detaylar Arkaik dönem Batı Anadolu karakteristiklerini kesin olarak yansıtmaktadır. Heykel bulunduğu sezonun raporunda "Heykelin konusu tam olarak anlaşılmasa bile, tekniği batıya özgü arkaik heykel karakteristiği taşımaktadır" (Summers 2011, 6) şeklinde tanımlanmıştır. Daha sonraki çalışmalarda ise Kerkenes'te ele geçen heykeltıraşlık eserlerinin Yakın Doğu, Phrygia ve Ionia/Lydia etkisi taşıdığı, ancak büyük oranda ya da tamamen Phryg üretimi olduğu belirtilmiştir (Summers 2013b, 227-228). Detaylı yayının yapılmamış olmasına karşın, mevcut durumuyla bu eserin Batı Anadolu ve büyük ihtimalle de Lydia üretimi olabileceği önerilebilir.

Saray kompleksi kazılarında heykel kaidesinde kullanılanlarla aynı formda ama büyük boyutlu polster parçaları da ele geçmiştir ve bu polsterlerin $1 \mathrm{~m}$ çapında ahşap sütunların üzerinde başlık olarak kullanılmış olabilecekleri önerilmiştir (Summers 2006a, 176-177, Fig. 12a). Dönemi düşündüğümüzde karşılaştırılabilir örnekleri batıdan bilinen bu uygulamanın, Batı Anadolu etkisinde ya da üretimi olduğunu varsaymak kabul edilebilir bir öneri olarak gözükmektedir. Aynı şekilde, saray kompleksi anıtsal girişinde bazı işlenmiş blokların üzerinde ahşap ve metal kırlangıç kuyruğu kenetlerin tespit edilmiş olması Batı Anadolu'ya işaret eden bir diğer veridir. Hafiri tarafından, kırlangıç kuyruğu kenetlerin Anadolu'da en erken örneğinin Sardeis'te Alyattes Mezarında belgelendiği aktarılmakla birlikte erken dönemlerde Yakın Doğu merkezlerinde 
ve Gordion'da kullanılmış olduğu vurgulanmıştır (Summers 2006a, 178-179, Fig. 13a). Saray kompleksi olarak adlandırılan yapıdaki heykeltıraşlık eserlerinin yanı sıra mimari detaylara da dikkatli ve objektif bir gözle bakıldığında Batı Anadolu karakteristiklerini kesin olarak tespit etmek mümkündür. Yukarıda değinildiği üzere, askeri bir garnizon olarak kurulduğunu ve içine yerleştirilen ordunun farklı topluluklardan oluştuğunu düşündüğümüz Kerkenes yerleşiminde detaylarda farklı kültürleri bütünde ise kompozit bir yapıyı görmemiz kaçınılmaz bir sonuç olacaktır.

Kerkenes'te yerleşimin tek tabakalı oluşu ve kentte yaşayanların değerli eşyalarıyla birlikte terk ettikten sonra yerleşimin yakılmış olması sebebiyle çok fazla buluntu ele geçmemektedir. Ele geçmiş az sayıdaki buluntuların en iyi tanınanı muhtemelen 1996 yılında test kazıları sırasında, daha sonra Yapı Bloğu 8 olarak tanımlanan yapı kompleksinin bir mekanında, ele geçmiş olan fildişi levhadır. E. R. M. Dusinberre (2002, 17 vd.) tarafindan detaylı olarak incelenmiş olan eser, altın yaldız ve kehribar ile kakmalı kabartma bir mobilya paneli olarak tanımlanmıştır. Kısmen korumuş olan panel üst kısmında boncuk dizisi altta ise meander motifiyle sınırlandırılmış bir friz içermektedir. Friz bir erkek, bir dişi olacak şekilde sıralanan otlar şekildeki geyik, keçi ve koyun figürlerinden oluşmaktadır. MÖ 580/70 civarına tarihlenen Lydia üretimi eserin muhtemelen Lydialılar ve Medler arasındaki bir hediye değişimi ile ilgili olabileceği önerilmiştir (Summers 2000, 69, Fig. 11; Dusinberre 2002, 45). Yerleşimin bir Lydia garnizonu olduğu düşünüldüğ ünde ise bu eserin bir hediye olmadığ sandığına ait olduğu, ancak ordu geri çekilirken taşınamadığ için götürülmemiş olduğu önerilebilir. Kapadokya Kapısı kazılarında yangın tabakasının altında taş kaplama üzerinde tespit edilen altın bir süs eşyası bir diğer Lydia eseridir. Arka kaplaması elektrondan yapılmış olan süs eşyasının paraleli bilinmemekle birlikte altın ve elektronun birlikte kullanılması ve genel düzenlemesiyle Lydia üretimi olarak tanımlanmıştır (Summers 2013b, 226-227, Fig. 4). Yerleşimde ele geçen bu buluntular Lydia'nın kültürel varlığına işaret etmektedir, ayrıca askerlerin aileleri ve köleleriyle birlikte yaşamış olduklarını da göstermektedir.

Yerleşimde günümüze değin bulunan seramiklerin detaylı bir yayını henüz yapılmamıştır. Yayınlanan örnekler ve verilen bilgiler de Alişar V tipi olarak tanımlanan Orta Anadolu tipi seramikler bulunduğu ve Batı Anadolu seramiği ele geçmediği şeklindedir (Summers 2014, 46). Tarafımızca yürütülen kazı çalışmalarında ele geçmiş çok yoğun seramik buluntunun büyük bölümü daha önce kısmen bahsedilen seramikler ile büyük benzerlik göstermektedir. Sur kazılarında iç kesimde ele geçen birkaç küçük parça seramik ise

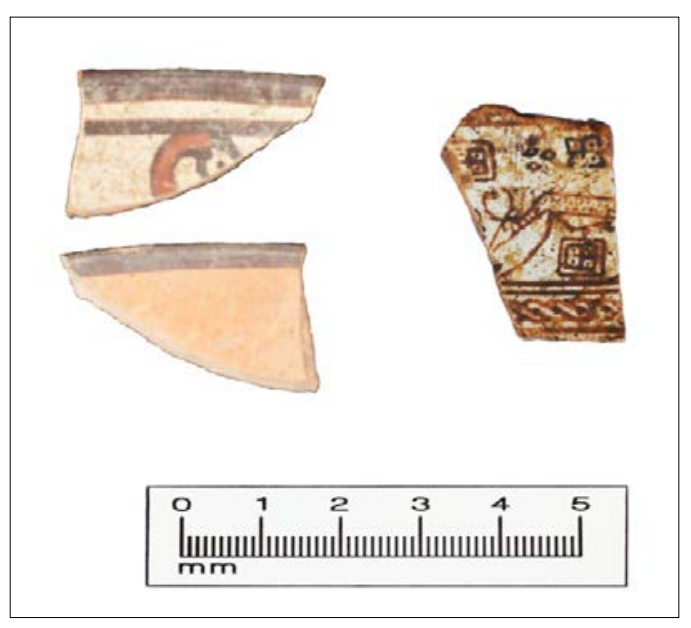

Fig. 9. Batı Anadolu kökenli seramik örnekleri (Fig. 9) bize Batı Anadolu seramiklerinin de kentte bulunmuş olabileceğini düşündürmektedir. Özellikle üzerinde nokta stilinde yapılmış geyik figürünün bir parçası görülebilen orientalizen stilde bir seramik parçası dikkat çekicidir. En yakın örneklerini Batı Anadolu merkezlerinde bulabildiğimiz bu parça içe kapanık bir yerleşim olmadığını gösteren bir diğer veridir (Karşılaştırılabilir örnekler için bk. Greenewalt 1970, Pls.1-4; Kerschner 2006; Fig.7).

Bir yerleşimin kültürel kimliği ancak üretim faaliyetleri ile ölçülebilir bir durum olduğu için yerel üretim atölyeleri tespit edilmediği sürece, ele geçen buluntuların sadece orada yaşayan in- 
sanların kullandıkları malzemeler hakkında bilgi verdiği söylenebilir. Bu bağlamda yukarıda değinildiği üzere egemen gücün kim olduğu konusunda da buluntular çok fazla anlam ifade etmemektedir. Mimari üretimler ise özellikle de anıtsal yapılar toplumsal amaçlı oldukları ve genellikle de egemen güç tarafından yaptırıldıkları için bu bağlamda daha yardımcı olmaktadır. Kerkenes'in karakterini en iyi yansitabilecek anıtsal yapısı şüphesiz sur duvarlarıdır. Dönemindeki Anadolu yerleşimlerinin en büyük boyutlu olmasıyla da önem arz eden sur duvarları tamamen taştan inşa edilmiştir. Eğimli destek duvarı ile güçlendirilmiş sur duvarı oldukça korunaklı durumda yedi kapı ve çok sayıda kule ile donatılmıştır. 1,5 x 2,5 km ölçüsündeki yerleşimin çevresindeki yüksek konturları takip eden Kerkenes sur sistemi yukarıda değinildiği gibi askeri bilgiye sahip uzman kişilerce inşa edilmiştir. Bu boyutta bir yapının da güçlü ekonomiye sahip bir otorite tarafından desteklenmiş planlı bir girişimin sonucu olduğu konusunda şüphe bulunmamaktadır.

Sur duvarının en karakteristik unsuru düşmanın duvar dibindeki kör noktaya ulaşarak duvara zarar vermesini engelleme amaçlı inşa edilmiş eğimli destek duvarı (glacis) uygulamasıdır. Toprak kaymalarıyla sur duvarının göçmesini engellemek, estetik bir bütünlük katmak, sur duvarı dibinde bitkilerin yetişmesini önlemek ve yağmur sularını duvara zarar vermeden uzaklaştırmak gibi işlevleri de taşımış olabilecek eğimli destek duvarı Erken Bronz Çağı'ndan itibaren bilinmekle birlikte Anadolu'da az sayıda örnekle temsil edilmektedir. Kerkenes, Keykavus Kale, Göllüdağ, Akalan, Kululu yakınlarında Havuzköy, Yozgat merkezde Çeşka Kale, Yaraşlı yakınında Çevre Kale, Boğazköy, Gordion, Sardeis ve Phokaia bilinen örneklerdir (Vergnaud 2012, 172-176). Bunlardan Havuzköy örneğinin Hitit dönemine ya da Demir Çağı'na ait olabileceği de vurgulanmışır. Boğazköy'de Yerkapı yakınındaki Hitit dönemi duvarlarının etkisinde yapılmış olabilecek Büyükkale'nin güney kesiminde Demir Çağ'a ait bir bölüm açığa çıkartılmıştır. Çevre Kale'de eğimli destek duvarı sur duvarına dayanmış bir taş yığını şeklindedir ve üst yüzeyleri duvar örgüsü haline getirilmemiştir. Yozgat merkezdeki Çeşka Kale araştırmacılar1 tarafindan MÖ IX.-VIII. yüzyıllara tarihlendirilmiştir ve daha önce Akhamenid döneme ait olduğu önerilen Kerkenes içindeki Keykavus kalenin de aynı tarihten olabileceği önerilmiştir (Vergnaud 2012, 40). Kerkenes yakınındaki glacis olarak tanımlanmış kaplamalara sahip Gözbaba ve Tilkigediği tepenin daha önceden Akhamenid döneme ait gözetleme kuleleri olabileceği önerilmesine karşın yukarıda değerlendirildiği üzere tümülüs olabilecekleri de olasıdır. Göllüdağ sur duvarlarının eğimli destek duvarına sahip olduğu belirtilmekle birlikte henüz detaylı inceleme yapılmamış ve yayınlarda da yeterli bilgi verilmemiştir. Samsun Akalan'da eğimli destek duvarları Kerkenes ile büyük benzerlik gösterir, ancak daha kabaca inşa edilmiştir. Gordion'da yoğun bir toprak dolgu yapılmış ve dolguyu bir arada tutmak için basamaklı büyük bir teras inşa edilmiştir. Sardeis'te ise toprak ve moloz tabakalardan oluşan yığın taş ile kaplanmıştır. Phokaia'da sadece küçük bir bölümde görülebilen eğimli destek duvarı işlenmiş büyük bloklardan yapılmıştır ve sistem olarak Kerkenes ile büyük benzerlik göstermektedir. Klazomenai'da açığa çıkartılan küçük bir bölümdeki eğimli yerleştirilmiş blokların ise tanımlaması ve sur duvarıyla ilişkisi kesin değildir (Vergnaud 2012, 172-176). Son y1llarda Milas Ortabelen'de tespit edilen eğimli destek duvarına sahip bir sur duvarı kısmen kazılmış fakat henüz yayınlanmamıştır.

Bu örneklerin Gordion'u da kapsayan büyük bölümünde eğimli destek duvarı sur duvarının ön kısmında alt seviyedeki toprağın kayması ve duvarın tahrip olmasını engellemek amaçı teras duvarı olarak işlev görmüştür. Sardeis, Kerkenes, Akalan ve Phokaia'da ise eğimli destek duvarı mimari anlamda sur duvarını güçlendirmek için payanda işlevi görecek şekilde yani sur duvarının organik bir parçası olarak inşa edilmiştir (Vergnaud 2012, 176). Niğde, Göllüdağ surları ile ilgili detaylı bilgi bulunmamakla birlikte yerleşimin genel düzenlemesi ve tamamı taştan yapılmış sur duvarının çevredeki hakim noktalardan geçmesi Kerkenes ile benzerlik göstermektedir. 
Bronz çağdan itibaren farklı kültürlere ait yerleşimlerde görülen eğimli destek duvarının kesin bir gelişim süreci belirlenememiştir. B. Vergnaud (2013, 233 vd.) tarafından yapılan çalışmalarda Phryg yerleşimlerinde Phryg kimliği ya da stilini gösterebilecek karakteristik bir sur gelişimi bulunmadığı belirlenmiştir. Bu nedenle, bağımsız Pteria krallığının Phyrg kültüründeki halkı tarafından yapılmış olduğu önerilen Kerkenes surlarının Phryg kültürüne ait olarak tanımlanması için elde veri bulunmadığ 1 bilinmektedir. Elbette, topografya, stratejik konum ve kullanılacak malzeme temini gibi pek çok unsurun belirleyici olduğu sur inşasında kesin karakteristiklerin tespit edilmesi kolay değildir. Ancak, yukarıda değinildiği gibi Kerkenes, Akalan, Sardeis, Phokaia ve olasılıkla Göllüdağ yerleşimlerinde eğimli destek duvarlarının sur duvarının organik bir parçası olarak inşa edilmiş olmalarıyla ortak bir karakteristik göstermektedir.

Denizden 2143 m yüksekte yer alan Göllüdağ yerleşimi doğal su kaynağına sahip hakim bir konumdadır. Yerleşimin çevresindeki yüksek noktalardan geçen ve dağı çevreleyecek şekilde inşa edilmiş etkileyici büyüklükteki taş surları ile sur içinde kalan alanın dik açılı bir sistem izleyecek şekilde planlanması ve sur kapılarındaki düzenlemeler Kerkenes ile benzerlik göstermektedir (Summers 2003, 12-13). 5 km uzunluğunda tamamı taştan yapılmış sur duvarlarında 4 adet kapı tespit edilmiştir. Kerkenes ile karşılaştırıldığında düzenli bir planlamaya sahip daha az yoğunluklu olan yerleşimdeki mekanların dinsel yapılar ya da saray amaçlı olduğu düşünülmektedir. Çok kısa ömürlü olduğu belirtilen yerleşimde saray yapısının MÖ VIII. yüzyılda inşa edildiği ve en geç MÖ VII. yüzyıl başlarında terk edildiği düşünülmektedir Surların da yerleşimle aynı zamana MÖ VIII. yüzyıla tarihlenebileceği önerilmiş ancak, çalışma yapılmamıştır (Bittel 1970, 147; Vergnaud 2012, 172). Her ne kadar yeterli arkeolojik veri bulunmasa da, MÖ 590-585 arasındaki Medlerle yapılan savaşın bu bölgede gerçekleşmiş olduğu büyük bir olasılıktır. Yerleşim çok kısa süreli araştırıldığı için yeterli arkeolojik veri bulunmamakla birlikte yerleşimin Kızılırmak'ın güneyindeki yolları kontrol eden hakim konumunun yanı sıra Kerkenes ile genel düzenleme ve sur sistemi de benzerlikler göstermektedir. Bu benzerlikler, daha önceden boşaltılmış olan bu kutsal alanın Kimmerler ile savaşılan dönemde Lydia garnizonu olarak kullanılmış olabileceğini akla getirmektedir. Yollara hakim konumu nedeniyle Lydler tarafindan seçilen ve surla çevrelenerek askeri garnizon haline getirilen yerleşimin Medlerle yapılan antlaşma uyarınca da Pers savaşlarına değin Lidya egemenliğinde kalmış olabileceğini önermek şimdilik çok olanaksız gözükmemektedir.

Samsun Akalan yerleşimi Amisos'tan başlayarak Havza üzerinden Kızılırmak boyunca güneye ilerleyen yolu korumak amaçlı kurulmuş olmalıdır, ancak aynı zamanda $40 \mathrm{~km}$ güneydeki doğu batı doğrultusundaki yolu da kontrol altında tuttuğu muhtemeldir. $300 \mathrm{~m}$ uzunluk ve 50-70 $\mathrm{m}$ genişlikte bir alanı kaplayan yerleşimde topografyaya uydurularak inşa edilmiş sur uzunluğu 1000 m civarındadır ve ortalama yükseklikleri 4,50-5,00 m civarında korunmuştur. Güneyde dik yamaca, kuzeyde ise daha yumuşak eğimli yamaca göre inşa edilmiş eğimli destek duvarı, büyük blokların arasına daha küçük taşların kama şeklinde yerleştirildiği duvar tekniği ve eğimli destek duvarının surun organik bir parçası olmasıyla Kerkenes'e büyük benzerlik gösterir. Kazı çalışmalarında eğimli destek duvarlarının bir kısmı ile kale içindeki anıtsal bir yapıya ait pişmiş toprak mimari elemanlar açığa çıkartılmıştır. Yerleşimde ele geçen en erken seramik MÖ VII. yüzyılın son çeyreğine, pişmiş toprak elemanlar ise MÖ 550-525 arasına tarihlendirilmiştir. Tepe üstünde yer alan kalenin tek yerleşim alanı olmadığı ve çevresindeki düzlük alanlarda yer yer seramik buluntuları görüldüğü için bir dış yerleşim bulunduğu önerilmiştir (Dönmez 2004, 67 vd.; Summerer 2008, 266-270; Johnson 2010, 397-398; Vergnaud 2012, 39, 173). Kerkenes surlarındakilere göre birbirine iyi oturmayan daha kaba taşlardan inşa edilmiş olan Akalan surlarının kesin tarihi bilinmemekle birlikte en erken seramiklerin MÖ VII. yüzyılın son çeyreğine ait olması ve MÖ VI. yüzyıl sonrasından buluntu olmaması ile de Kerkenes ile paralellik göster- 
mektedir. Ş. Dönmez $(2007,1208)$ Kerkenes ile olan büyük benzerliğin Akalan'1 kuran topluluğun antikçağ Hellen Dünyası ile değil, Orta Anadolu Bölgesi ile bağlantıda olduğunu gösterdiğini ve MÖ VII. yüzyıl sonlarında Karadeniz halkı tarafından Kimmer veya İskitlere karşı korunmak amaçlı inşa edilmiş olduğunu önermiştir. P. Johnson $(2010,298)$ ise Akalan ve Kerkenes arasındaki benzerlikleri dikkate alarak Akalan'ın Kerkenes'teki Demir Çağ krallığına bağlı olduğunu önermiştir. Amisos limanından güneye uzanan yolun haricinde doğu-batı doğrultusundaki ana yolu da kontrol altında tutan yerleşimin askeri karakteri ve Kerkenes ile olan benzerlikleri Lydia garnizonu olduğu önerisini desteklemektedir.

Bilinen tek Lydia üretimi sur olan Sardeis'in arkaik dönem sur duvarlarının Roma dönemi suruyla aynı hattan geçtiği düşünülmektedir. Akropolden başlayarak doğal sırtları takip eden 3,5 km uzunluğundaki sur duvarının 16-35 m arasında yüksekliğe sahip olduğu tahmin edilmektedir. MÖ VII. yüzyılın son çeyreğinde taş temel üzerinde kerpiç tuğlalardan inşa edilmiş $20 \mathrm{~m}$ kalınlığındaki sur duvarına MÖ VI. yüzyılın ilk yarısında eğimli destek duvarları eklenmiş ve kalınlık 40 m'ye ulaşmıştır. Önceki evrenin taş temellerini kaplayacak ve destek verecek şekilde organik bağ gösteren eğimli destek duvarı toprak ve moloz katmanlarından oluşmaktadır. $\mathrm{Bu}$ destek dolgusunun üst kısmı da taş kaplanarak sudan zarar görmesi engellenmiştir. Sardeis sur kapısı avlulu düzenlemesiyle Gordion ile karşılaştırılabilmekle birlikte Sardeis'te avlunun ön kısmı dışa açık iken Gordion'da hem ön hem de arkada koridorla sınırlanan avlu düzenlemesi bulunmaktadır. Kerkenes Kapadokya kapısının Gordion ve Sardeis etkileşiminin sonucu olabileceği düşünülmektedir (Vergnaud 2012, 47-50, 216-221). Kimmer tahribatından sonra başlanılan sur inşa programında Kerkenes surlarından hemen önce yapılmaya başlanılan Sardeis kent surlarının eğimli destek duvarları yine Alyattes döneminde daha sonradan eklenilmiştir. Tam tarih bilinmese de özellikle Kerkenes inşa edilirken mimarların Boğazköy gibi bölgedeki erken örnekleri görmüş ve teras desteği olarak kullanılan bu sistemi duvarın destek kısmını oluşturmak üzere taşın bol bulunduğu yerleşimde ilk olarak inşa etmiş olmaları mantıklı bir açıklama olarak önerilebilir. Sistemin işlerliğinin test edilmesi sonrasında da Göllüdağ ve Akalan'da uygulanan eğimli destek duvarının Sardeis'te eldeki malzemeyle bağlantılı olarak toprak ve moloz katmanlarıyla inşa edilmiş olduğu kabul edilebilir bir açıklamadır.

Benzer teknik özelliklerin görüldüğü bir diğer örnek ise Phokaia surlarıdır. Sur hattı takip edildiğinde mevcut izler yardımıyla yaklaşık $5 \mathrm{~km}$ uzunluğunda olduğu tespit edilen sur duvarının oldukça küçük bir bölümü görülebilir durumdadır (Özyiğit 1994, 77-109; Vergnaud 2012, 76, 87-88, 130, 135, 152-153.). Kerkenes ile aynı formda düzenlenmekle birlikte kazılan kısımdan görüldüğü kadarıyla tamamen işlenmiş bloklardan inşa edilmiştir. Temeline kadar kazılmamış olan korunmuş bölümde sur yüksekliği 3,36 m olarak belirtilmiştir. MÖ 590-580 arasında Herodotos'un (I. 163) aktardığına göre İspanya'daki Tartessos kralı Argonthonios'un Medlere karşı kendilerini koruması için verdiği parayla sur duvarları inşa edilmiştir. Alyattes ve Kroisos dönemleriyle ilgili anlatımlarında Phokaia'dan hiç bahsetmezken Phokaia surları için böyle bir hikaye aktarılması ilginçtir. Ayrıca, Kimmer istilasından sonra Medlerin Batı Anadolu'yu tehdit ettiklerine dair bir veri bulunmamaktadır. Arkeolojik verilerin gösterdiği üzere MÖ 590 civarında inşa edilmiş olan surun ileri teknik detaylar göstermesi ve Lydia'nın bu kadar yakınındaki bir yerleşimde tamamı kesme taştan $5 \mathrm{~km}$ uzunluğunda bir sur inşasının Lydia izni ve desteği olmaksızın yapılabilmiş olması çok gerçekçi değildir. Kerkenes ve Sardeis surlarıyla aynı dönemde ve benzer teknikte inşa edilmiş Phokaia surlarının tamamen kesme taştan yapılmış olması, yüksek maliyetin ötesinde yetişmiş insan gücüne de yoğun ihtiyaç duyulduğunu göstermektedir ve en mantıklı açıklama Lydia krallığının desteğiyle yapılmış olmasıdır. Herodotos (I. 22) tarafından Alyattes'in Miletos ile yaptığı savaş ve sonrasında iki tapınak inşa ettirerek antlaşma yapmış olduğunun aktarılması Phokaia için de benzer bir durum olabilir mi sorusunu akla 
getirir. Herodotos tarafindan bilinmeyen bir başka antlaşmayla da deniz gücü ve limanıyla ünlü Phokaia'ya Alyattes tarafından destek verilmiş olabilir. Bağımsızlıklarını kaybettikleri imajını vermemek için Phokaialıların böyle bir hikaye yaratmış oldukları ya da Herodotos zamanına değin sponsorun kim olduğu konusunun değişik bir hikaye haline geldiği olası bir açıklama olarak kabul edilebilir gözükmektedir.

Kerkenes ile birlikte bu beş yerleşimin benzer mimari karakteristikleri göstermesi ve inşa dönemlerinin aynı evreye gelmesi bir tesadüf olarak tanımlanmamalıdır. Yaklaşık 100 yıl boyunca Batı Anadolu'nun hakimi ve doğudan gelen tehditlerin karşısında duran tek gücü olan Lydia'nın Sardeis haricinde hiç tahkimat yaptırmadan bu gücünü korumuş olması çok olası değildir. Kimmer saldırısında Sardeis'in tahrip edilmesi sonrasında Alyattes tarafindan Sardeis'in surları oldukça büyük boyutlu olarak inşa ettirilmiş ve bu evrede yağmacı Kimmerlere karşı en etkili savunma aracı olduğu görülen güçlü surların yukarıda değindiğimiz gibi güvenli bir doğu hattı oluşturmak üzere Kerkenes, Göllüğgă̆ ve Akalan'da da uygulanmasına karar verilmiş olmalıdır. Eş zamanlı bu dört projenin Alyattes'in Kimmerleri yenerek Asya'dan sürmüş olmasında rol oynamış olduğu büyük bir olasılıktır. Surların inşası için Gordion ya da teras olarak düzenlenmiş eğimli destek duvarı bulunan Hattuşa ya da Çevre Kale gibi merkezler örnek teşkil etmiş olmalıdır. Lydia krallığının taş mimaride oldukça gelişmiş olmasının yanı sıra Karia ve Ionialı mimar ve ustaların da krallığın emrinde olduğu varsayıldığında Kerkenes sur duvarların inşası ve arkasındaki güç daha anlaşı1ır hale gelmektedir. Askeri bir bilgiye sahip mimar ve mühendisler tarafından inşa edildiği konusunda hiç şüphe bulunmayan 7,5 km uzunluğunda, 7 x 7 m ölçüsünde ki, tamamı taştan yapılmış sur duvarında yaklaşık $400.000 \mathrm{~m}^{3}$ taş dolgu kullanılmıştır. Sadece taş dolgu için gereken işgücü kendi başına büyük bir maliyet oluştururken yukarıda değindiğimiz mimari detaylara bakıldığında uzman taş ustalarının bulunduğu çok sayıda işçinin çalışmış oldukları söylenebilmektedir. Tüm bu detaylar, dönemin en büyük gücü olan ve güçlü maddi olanaklara sahip olmasının yanı sıra uzman kişilere de kolaylıkla ulaşabilir durumdaki Lydia krallığının bu projedeki rolünü net olarak yansıtmaktadır.

G. Summers (2013a, 138) tarafindan kentin en dikkat çeken üç özelliği olarak kentin oldukça geniş bir görüş hakimiyetine sahip stratejik konumu, dönemine göre oldukça ilerilik gösteren tahkimatının boyutu ve kent içindeki yerleşim yoğunluğu gösterilmiştir. Yerleşimin kış aylarında oldukça soğuk olan yüksekteki konumu, güneydeki daha yüksek kesim haricinde oldukça hakim bir görüş açısı sağlamaktadır ve askeri amaçla kurulmuş olduğunu destekleyen bir durumdur. Bu stratejik konum kentin sadece çevresini değil $15 \mathrm{~km}$ ilerden geçen üç önemli ticaret yolunu da kontrol etmesine imkan vermektedir. Bunlardan ikisi Samsun ve Sinop'tan gelen ve Kerkenes yakınında birleşerek Kayseri'ye doğru uzanan kuzey-güney yollarıdır. Üçüncü yol ise bugünkü karayolunun uzandığı doğu batı yoludur (French 1989, 143; Branting 2004, 49-53). Sur boyutu ve yerleşim içindeki yoğunluk da ancak büyük bir ordunun burada bulunması ile açılanabilecek bir durumdur. Bir diğer ilginç durum ise kentin surlarında 7 kapı bulunduğu ve bu kapıların çevredeki tarım arazilerine en kolay ulaşacak şekilde değil de ana yolları takip edecek şekilde topografyaya uygun konumlandırılmış olmasıdır (Summers 2013a, 138, Fig. 2-3). Kentin çevresindeki alanlar günümüzde olduğu gibi eski çağlarda da tarımsal açıdan oldukça faal olmalıdır ve kent planlanırken tarımsal arazilere en kolay şekilde ulaşımın temin edilmesi beklenirken, yol güzergahlarının kapılar için belirleyici olması kentin askeri kimliği ile açıklanabilecek bir başka durumdur.

Kentin yerleşim düzenine ve konutların dağılımına baktığımızda da benzer sonuca ulaşılabileceği görülmektedir. Kentte yürütülen jeofizik çalışmalarda farklı ölçüde 757 adet yapı bloğunun bulunduğu tespit edilmiştir. En büyüğü $26.500 \mathrm{~m}^{2}$ olarak ölçülen bloklar kuzey ve güney 
bölümlerde daha büyükken doğu ve batı bölümlerde özellikle kentin merkezi kısmı ile kale çevresinde daha küçük boyutludurlar. Birbirilerinden sokak ve caddelerle ayrılmış ve duvarlarla s1nırlandırılmış bölümlerde taş döşeli avlularla ayrılmış çok sayıda yapı barındıran bu adalardan 8 numaralı örnek son yıllarda kazılmaktadır. Toplam $6.000 \mathrm{~m}^{2}$ ölçüsüyle oldukça büyük bir alana konumlanmış 8 numaralı yapı bloğu diğer blokların da anlaşılması için önemli bir örnek oluşturacaktır (Branting 2004; 2016, 1 vd.). Kentte yapılan kazıların sınırlı olması yapı blokların işlevinin anlaşılmasını zorlaştırmakla birlikte jeofizik ölçümlerle tespit edilen planlara bakıldı̆̆ında, öncelikle kesin geometrik formların çok yaygın olmadığı göze çarpmaktadır. Ayrıca, yapı bloklarının iç kısmında birbirinden bağımsız dikdörtgen formlu yapılar ve yan yana sıralanmış odaların herhangi bir kural olmaksızın dağıtılmış bir görüntü verdiği görülmektedir (bk. Branting 2004; Summers 2004; 2006c; Langis-Barsetti 2013). Kentte tek evrenin bulunduğu bilinmese ilk akla gelecek olan yapıların devam eden dönemler boyunca eklenerek yapı bloklarının bir mahalle tarzında oluşturulduğu ve aralarındaki cadde ve sokakların da zaman içerisinde oluştuğudur. Yeni kurulan ve eşit bir şekilde halkına dağıtıldığı düşünülen bir kentte daha kesin bir planlama ve düzen beklenilmesi kaçınılmazdır. Günümüze değin yapılmış sınırlı kazılar bu yapı bloklarında mutfak ve depo gibi işlevler görmüş mekanlar ile merkezi büyük bir yapının bulunduğunu göstermekle birlikte gündelik yaşamın sürdüğü normal bir ev görüntüsünü tam olarak yansıtmamaktadır. Her birinin içinde onlarca mekan bulunan 757 adet blok yerleşimin nerdeyse tamamını kapsamaktadır. Kabaca yapılacak bir hesaplamada her bir mekanda 10 kişi düşünüldüğünde, bir yapı bloğunda 100 ve toplamda da yaklaşık 80.000 kişiyi rahat bir şekilde barındırabilecek bir yapılaşma ile karşı karşıya bulunduğumuz kabul edilebilir. Karşılaştırılabilir normal bir kent ölçeğinden çok daha büyük olan ve tamamı mekanlarla donatılmış Kerkenes'in dönemine göre pek çok istisnai özelliği bilinmekle birlikte, yukarıda değindiğimiz gibi kentin askeri bir garnizon olduğu kabul edildiğinde bu yapılaşmanın da mantıklı bir açıklaması yapılabilmektedir. Farklı topluluklardan oluşturulan bir ordunun kentin surları inşa edilirken askeri birliklerin büyüklüğüne göre kente dağılarak kendilerine mekanlar yaratmış oldukları düşünülebilir. Böylece, her bir askeri birliğin nüfus özelliklerine göre mekanlar oluşturduğu ve kendi birliklerini diğer birliklerden ayırt etmek için bu mekanların çevresini duvarlarla çevirerek yapı bloklarının ortaya çıkmış olduğu kabul edilebilir bir açıklama olarak gözükmektedir.

Kentte yine jeofizik araştırmalara göre daha önce 6 adet büyük yapı tespit edilmiştir. Bunlar mekan içinde ahşap sütunlarla desteklenen beşik çatı örtülerine sahip olmalıdır. Saray kompleksindeki kabul salonu $34 \times 22 \mathrm{~m}, 748 \mathrm{~m}^{2}$; kuzeybatı salon $26,5 \times 19,504 \mathrm{~m}^{2}$; tapınak $28 \times 15$, $405 \mathrm{~m}^{2}$, Kuzeydoğu salon $28 \times 15,405 \mathrm{~m}^{2}$, güneydoğu salon, $28 \times 15,405 \mathrm{~m}^{2}$, kesme taş yap1 18x9 m, $162 \mathrm{~m}^{2}$ ölçüsündedir (Summers 2007, 250-260). Kuzeybatı salon olarak tanımlanan

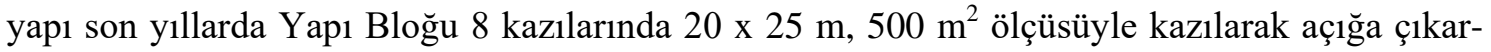
tılmıştır. Kentin farklı noktalarında tespit edilen bu yapıların boyutları sosyal işlevlerine işaret etmektedir ve bunlardan saray yapısındaki Kabul Salonu, kentin orta kısmındaki bir yapı ise tapınak olarak tanımlanmıştır. Tapınak olarak tanımlanan yapı ile aynı plana ve ölçülere sahip iki adet daha yapının bulunması ilgi çekicidir. Aynı ölçüde aynı planda kentin farklı noktalarında üç adet yapı bulunması yapı bloklarındaki düzensizliklerle uyumsuz bir durum yaratmakla birlikte aynı ulustan farklı birliklerin kendi yapı bloklarında benzer plandaki yapıları aynı mimara yaptırmış olması akla gelen ilk olasılıktır. Henüz detaylı yayını yapılmamış olmasına karşın, Saray Kompleksi'ndeki kabul salonuyla benzer plana sahip Yapı Bloğu 8 içindeki yapıda ele geçen az miktardaki buluntu mekanın işlevinin kabul salonu ya da daha büyük olasılıkla bir andron olabileceğini düşündürmektedir. Benzer ölçülerdeki bu mekanın varlığı aslında kentte bir kral yerine farklı askeri birliklere sahip komuta kademesinin bulunmuş olabileceğini, yani kentin askeri kimliğini daha iyi açıklamaktadır. 
Bu kadar yoğun bir nüfusu barındıran yerleşimde en temel sorunlardan birisi su temini olmalıdır. Her ne kadar Kerkenes dağının eski çağlarda ormanlık olduğu ve dolayısıyla daha fazla su kaynağına sahip olduğu düşünülse de bu konuda henüz bilimsel bir çalışma yapılmamıştır (Summers 1995, 45). Günümüze bakıldığında aşağı düzlükte bulunan köylerin en temel sorunu su ihtiyacıdır ve köylüler hem kendileri hem de hayvanları için su bulmak konusunda büyük s1kıntılar yaşamaktadır. Kerkenes Dağı'nın varlığı yerleşimin günümüzde en sıcak ve kurak dönemlerde bile aşağıdaki düzlüklere göre daha sulak kalmasını sağlamasına karşın, su kaynaklarının yerleşimde önemli rol oynadığ 1 ve herhangi bir sıkıntı yaşanmaması için tedbirler alındığ 1 görülmektedir. Kentin güneyindeki Kiremitlik mevkiinden başlayıp kuzeye kadar uzanan ve yanlardaki yükseltilerden beslenerek "Su Kapl" adı verilen sur kapısındaki oluşturulmuş kanal aracılığıyla dışarı atılan akarsuyun varlığı kentin seçilmesinde rol oynamış olmalıdır. Ayrıca yerleşimde bugün yazın en kurak dönemlerinde bile akan suyu bulunan köylüler tarafından yapılmış çeşmeler bulunmaktadır ki, bu çeşmelerin çok eskilerden beri kullanımda olduğu muhtemeldir. Bu su kaynaklarına rağmen kentte su depolamak için de göletler oluşturulmuştur. Kapadokaya Kapısı'na yakın bir konumdaki bugün Sülüklü Göl olarak tanımlanan yapay gölet 32x56 m ölçülerinde $5376 \mathrm{~m} 3$ su kapasiteli olarak hesaplanmıştır. $3 \mathrm{~m}$ derinlikte tamamen taş temelli olan havuzun tüm yazı geçirebilecek ölçüde su depoladığı kabul edilmektedir. Kentteki diğer su deposu olarak işlev görmüş yapılardan en büyügü aşağı kentteki Büyük Göl olarak tanımlanan yapıdır ancak bu örneklerin hiçbirinde taş iş̧̧iliği tespit edilememiştir (Summers 1996, 213; 2000, 62, Fig. 4; 2013b, 226). Su kaynaklarının varlığ elbette bir yerleşim için en elzem noktalardan birisidir, ancak Kerkenes’teki tüm bu düzenlemeler kentin geniş ve güçlü surları içindeki kalabalık ordusunun uzun süreli kuşatmalara dayanabilmesi amacı içermiş olduğunu düşündürmektedir.

\section{Sonuç ve Değerlendirme}

Ekibimiz tarafından 2012 ve 2013 yıllarında toplamda sadece 2 aylık bir süreçte çalış1labilmiş olmasına rağmen Kerkenes yerleşiminde oldukça faydalı ve kapsamlı çalışmalar gerçekleştirilmiştir. Kentin ulaşılabilirlik potansiyelinin artırılması haricinde, sur duvarında ve bir yapı bloğunda yürütülen kazılar kentin anlaşılmasına katkı sağlamıştır. MÖ VII. yüzyıl sonlarında kurulmuş ve MÖ 546 y1lında tahrip edilerek terk edildiği önerilen yerleşimin en dikkat çekici özellikleri oldukça geniş bir görüş hakimiyetine sahip stratejik konumu, dönemine göre oldukça ilerilik gösteren tahkimatının boyutu ve kent içindeki yerleşim yoğunluğudur. Kentin kış aylarında oldukça soğuk olmasına rağmen yüksek ve hakim konumda inşa edilişi savunma açısından kolay ve aynı zamanda doğu-batı ve kuzey-güney doğrultusunda uzanan anayollanı kontrol altında tutmak amacı taşıdığını yani kentin yerinin seçiminde askeri amaç bulunduğunu göstermektedir. $\mathrm{Bu}$ stratejik konum kentin sadece çevresini değil $15 \mathrm{~km}$ ilerden geçen üç önemli ticaret yolunu da kontrol etmesine imkan vermektedir.

En geniş yerinde 1,5 x 2,5 km ölçülere ulaşan Kerkenes yerleşimi Anadolu’nun bu dönemdeki en büyük yerleşimidir. Tamamı taştan inşa edilmiş yaklaşık $7,5 \mathrm{~km}$ uzunluğundaki sur sistemi kentin çevresindeki yüksek noktalardan geçecek şekilde düzenlenmiş ve en az 7 adet kap1 ile donatılmıştır. Kapıların tamamı kentin çevresinden geçen anayollara en kolay ulaşımı sağlamak amaçlı konumlandırılmış ve tarım alanlarına ulaşım çok fazla dikkate alınmamıştır. Sur duvarı 4-4,5 m genişliğinde olup sur duvarının mimari bir parçası olarak inşa edilmiş eğimli destek duvarının (glacis) 2-2,5 m arasında değişen genişliğiyle birlikte taban seviyesinde toplam genişlik 7-7,5 m arasında değişmektedir. $5 \mathrm{~m}$ yüksekliğinde korunmuş olan sur duvarı ve eğimli destek duvarının, üst kısımda yine tamamen taştan devam etmiş olduğu ancak günümüze kadar korunamadığı anlaşılmıştır. Üst kısmın askerlerin hem harekete edebileceği hem de korunabile- 
ceği bir şekilde düzenlenmiş olacağı dikkate alındığında mazgallarla birlikte 2,5 m civarında bir yüksekliğe sahip olabileceği ve böylece toplam yüksekliğin 7,5 metreyi bulduğu önerilebilmektedir. Çalışmalarımızda tespit edilen yerleşim içinden sur duvarına çıkılmasını sağlayan basamaklar, sur duvarının yapımındaki teknik detaylar, sur sisteminin konumu ve genel planlaması sur duvarlarının askeri bilgiye sahip, deneyimli mimar ve mühendislerin yönettiği ve taş işçiliğinde uzman kişilerce inşa edilmiş olduğunu gösterir. Boyutlarıyla da oldukça geniş ekonomik kaynaklara sahip bir otorite tarafından gerçekleştirilen planlı bir girişimin sonucu olduğu anlaşılmaktadır.

Surların içinde kalan yerleşim alanının neredeyse tamamı jeofizik araştırma sonuçlarının gösterdiği üzere sokaklarla birbirinden ayrılan 757 adet yapı bloğuyla kaplanmıştır. Kentte çok iyi düzenlenmiş bir su toplama sistemi bulunmasına rağmen normal bir yerleşimde beklenebilecek sosyal yapılar ve üretim alanları gibi kalıntılar tespit edilememiştir. En büyüğü $26.500 \mathrm{~m}^{2}$ olarak ölçülen yapı blokları birbirinden bağımsız yerleştirilmiş ve genelde düzenli bir dağılım göstermeyen bir büyük yapı, taş kaplı avlular ve çevresindeki daha küçük boyutlu yapılardan oluşmaktadır. Bu görünümüyle yapı bloklarının sadece konut alanı olarak kullanılmadığı ve kendi içinde bir hiyerarşiye sahip olduğu anlaşılmaktadır. Saray kompleksi olarak tanımlanmış yapının ise eğimli destek duvarlı terasları, giriş yolu ve anıtsal kapısıyla diğer yapı bloklarından ayrıldığı görülmekle birlikte genel düzenlemeye ve boyutlara bakıldığında idari bir yapı olabileceği daha büyük bir olasılık olarak gözükmektedir. Böylece yapı bloklarının her birinin kendi içindeki hiyerarşik düzenlemeyle belli bir askeri birliğe ait olabileceği ve bu farklı askeri birliklerin komutanlarının da Saray Kompleksi olarak tanımlanan yapıda bir araya gelmiş olabilecekleri kabul edilebilir bir açıklama olarak gözükmektedir. Alanda ele geçen kült objeleri ve heykeller de bu yapının idari karakterini yansitacak buluntulardır.

Kentle ilgili yapılan tespitler aslında şimdiye kadar yapılan tanımlama önerilerinin hiçbirisinin bu özelliklere karşılık gelmediğini gösterir niteliktedir. Kentin kuruluş sürecine bakıldığında bu boyutta büyük bir yatırımı yapabilecek iki güç olarak Medler ve Lydialılar gözükmektedir. Kentte ele geçen Phryg kültürüne ait buluntular ve Batı Anadolu kökenli mimari özellikler yerleşimin daha önceki Med kenti tanımlanmasının tamamen gözden uzak tutulması gerektiğini göstermektedir. Daha sonra yapılan Pteria krallığı başkenti tanımlaması da oldukça gerçek dış1 gözükmektedir. Bu derece büyük bir yerleşimin büyük bir ekonomik güç, nüfus yoğunluğu ve bilgi birikimine ihtiyaç duyduğu kesindir. Bu nedenle Lydia baskısından uzaklaşan Phryg kökenli bir halkın bu alana gelerek askeri amaçlı olduğu görülen Kerkenes yerleşimini kurmuş olabileceği ve Medlerle anlaşarak Lydia'ya karşı savaştığı önerisi kabul edilebilir bir açıklama değildir. Phryg ve Lydialılar arasında herhangi bir mücadeleye ilişkin veri bulunmamasının yanı sıra Gordion gibi pek çok yerleşimde Lydia ve Phryg kültürünün bir arada yaşamaya devam ettiği ve hem dinsel hem de idari anlamda pek çok ortak paydanın bulunduğu bilinmektedir. Ayr1ca, Lydialıların güçlendiği dönemde Phryg krallığı ile savaşmadığını aksine en önemli savaşını Phryg krallığını ortadan kaldıran Kimmerlere, yani ortak düşmana karşı gerçekleştirmiş olduğu bilinmektedir. Bu nedenle, Kimmerlere karşı savaşta Lydia ordusunun başta Phryg olmak üzere egemenliği altındaki tüm halklardan oluşturulduğu ve egemenliği altında olmayan çevredeki krallıklarla da antlaşmalar yapıldığı kabul edilebilir.

Anadolu'da ele geçen arkeolojik veriler Lydia krallığının egemenliği altındaki alanlarda kendi kültürünü yaymak gibi bir tutum içine girmediğini göstermektedir. Bu nedenle bir bölge ya da kentte Lydia unsurlarının net olarak görülmeyişi ya da Kerkenes örneğinde görüldüğü gibi Phryg kültürel unsurlarının baskın oluşu kentin Lydia egemenliğinde olmadığını göstermemektedir. Ayrıca yukarıda değinildiği gibi, Lydia üretimi buluntular da az sayıda olmakla birlikte 
kentte ele geçmiştir. Kerkenes’te halen çok küçük bir bölümün kazılmış olması buluntu karakterinin ilerde değişebileceğini ve farklı yapı bloklarında farklı kültürlere ait buluntuların ele geçebileceğini düşündürmektedir. Kerkenes’te Phryg yazıtları, kült objeleri ve Orta Anadolu üretimi seramiklerin ele geçmiş olması anlaşmalarla kurulmuş olduğu büyük oranda kabul edilebilen Phryg-Lydia ilişkilerini tam olarak yansıtan bir durum olarak kabul edilebilir. Ortak düşmana karşı Phryg halkının ağırlığı oluşturduğu bir ordunun kullandığ 1 objeler ve kalıntılarda kendi kültürlerini yansıtmış olmaları, ama sur duvarı gibi büyük boyutlu yapılarda Lydia'nın egemenliğindeki Phrygler ve Karialılar gibi farklı halkların bir arada üretimde bulunmuş olmaları kabul edilebilir bir açıklamadır.

Herodotos tarafindan Halys'ün Lydia krallığının sınırı olduğunun aktarılması yukarıda değinildiği gibi kesin bir tanımlama olarak kabul edilemez, ayrıca Medlerle ilgili verilen bilgilerin büyük oranda sonraki Pers dönemiyle karıştırılarak verildiği de bilinmektedir. Daha önceki evrede, yaklaşı 100 yıl boyunca Anadolu'da akınlar halinde yapmış oldukları saldırılar ile büyük sıkıntılar yaratmış olan Kimmerler ile ilgili bilgiler de oldukça sınırlıdır. Gyges'in Kimmerlere karşı Asurlulardan yardım istediğinin bilinmesi ve daha sonrasında Kimmerlerin akropolis hariç Sardeis'i ele geçirmiş olmaları ve Gyges'in ölümü, bu savaşın bilinenden daha büyük boyutlu ve kapsamlı olduğunu göstermektedir. Kimmer tahribatından sonra Sardeis surlarının oldukça büyük boyutlu olarak inşa edilmeye başlanmış olması ve mimari karakteristiklerinin Kerkenes, Samsun Akalan ve olasılıkla Niğde Göllüdağ yerleşimleri ile karşılaştırılabilir oluşu önemli bir veridir. Sardeis tahribatı ve Gyges'in ölümü sonrasında Lydia krallığının büyük boyutlu bir savaşa girdiği ve önceliği Kimmer akınlarına karşı dayanacak güçlü surlara sahip yerleşimler oluşturmak olduğu güçlü bir olasılık olarak karşımıza çıkmaktadır. Anadolu'yu Karadeniz'den Akdeniz'e uzanan düz bir hat üzerinde ikiye bölecek şekilde yer alan Akalan, Kerkenes ve Göllüdağ yerleşimlerinin (Fig. 6) hem sur mimarisi hem de yerleşim düzenlerindeki benzerlikler haricinde anayolları kontrol edecek şekildeki konumlarıyla da Lydia krallığı tarafindan oluşturulmuş askeri garnizonlar olarak tanımlanmaları mümkündür. Kimmerlerin egemenlik alanlarına saldırılarını sınırlarının ötesinde tutmayı Lydia krallığı oluşturduğu bu üç ana askeri garnizon ile başarmış olmalıdır. Sınırlarının ötesinde oldukça hakim konumdaki, güçlü surlara sahip bu üç yerleşim Kimmerlerin akınlarına karşı oldukça başarılı bir savunma taktiğidir ve aslında Lydia krallığının gücünü ve başarılarını yansıtan bir durumdur.

Kimmerleri Anadolu'dan sürdükten sonra Alyattes'in olasılıkla Göllüdağ civarında Medlerle yaptığı savaş MÖ 585 yılında galibi olmadan bir barış antlaşması ile bitmiştir. Herodotos'un Med-Lydia savaşının gerekçesi olarak aktardığı İskitlerin Alyattes'e sı ğınmış olmaları ve Med kralı Kyaksares'in istemesine rağmen Alyattes'in İskitleri teslim etmeyişi, gerçekleri temel alan küçük bir hikâye olmalıdır. Muhtemelen ortak düşman olan Kimmerlere karşı İskitlerle anlaşma yapmış olan Lydia krallığının doğuda garnizonlar kurması ve Medlere sıkıntılar yaratan İskitler ile anlaşmış olması savaşın gerçek nedeni olmalıdır. Savaşın 6. yılında bir güneş tutulması ile galibi olmadan bitmiş olması ve evlilik yoluyla yapılan bir barış anlaşmasının varlığı Lydia ve Med krallıklarının mevcut sınırlarının korunduğunu göstermektedir. Olasılıkla Kimmer tehlikesinin bitmesi ve Medlerle yapılan anlaşma sonrasında bu üç askeri garnizon asker sayısı azaltılmakla birlikte Lydia egemenliğindeki varlıklarını korumaya devam etmişlerdir. Bu kapsamda, Kroisos'un doğrudan Pteria olarak tanımlanan bölgeye gelmesi Perslere saldırmaktan ziyade kendi sınır hattına gittiğini gösterebilir. Bu açıklama kabul edilirse Lydia kralının kâhinlere sorduğu sorunun da düşmanı beklemesinin mi, yoksa karşı harekete geçmesinin mi, daha doğru bir hareket olacağı konusunda olmalıdır. Kroisos, Pteria cıvarına geldiğinde muhtemelen asker sayısı daha önce azaltılmış olan mevcut garnizonu güçlendirmek için çevredeki küçük yerleşimleri temizlemiş ve sıkıntı yaratabilecek toplulukları bölgeden uzaklaştırmış olmalıdır. Kanat anlamı- 
na gelen pteria kelimesinin de bir kent ismi yerine Lydia krallığının doğu kanadını yani sınırını betimlediği güçlü bir olasılık olarak önerilebilmektedir.

Kyros'un ordusuyla Pteria yöresine geldiği ve Kroisos'un ilk gün savaştıktan sonra Persleri yenemeyeceğini anlayınca ordusuyla Sardeis'e dönmüş olduğu bilgisi hem Kerkenes'in konumuyla hem de buluntu durumuyla uyum göstermektedir. Büyük bir ordunun fark edilmeden geri çekilmesini sağlayabilecek konuma sahip olan Kerkenes'te yürütülen kazı çalışmalarında yapıların bilinçli olarak boşaltılarak terk edildiği, heykellerin parçalandığı ya da saklandığı ve kentin farklı bölümlerinde çıkan eş zamanlı yangınlarla kentin kullanılamaz halde bırakıldığ 1 tespit edilmiştir. Kroisos'un geri çekilmesi sırasında kentin kapıları kapalı tutulduğu için eşyalarını toplayan ordunun gittiğini Kyros'un çok geç fark etmesi sağlanmış olmalıdır. Yerleşimde kazılan alanlarda savaş izlerinin ele geçmeyişi ve Kapadokya Kapısı kazısında tespit edilen iskeletlerin savaşırken değil, yıkıntıların altında kalarak ölmüş olduklarının tespit edilmiş olması bu görüşü desteklemektedir. Bu kapsamda, kentte gerçek anlamda bir yağmalama olayı söz konusu değildir, sadece yerleşimde yaşayan askerler ve aileleri taşınabilir tüm eşyalarını alarak kenti boşaltmış olmalıdırlar. Ordunun güvenli bir şekilde geri çekilmesi için gereken süre geçtikten sonra ise geride bırakılan az sayıdaki asker veya kişinin, Kyros tarafından kış aylarında kullanılmaması için kenti yakmış oldukları çok daha kabul edilebilir bir açıklamadır. Kroisos, bu sayede lojistik sıkıntıya düşecek Kyros'un geri döneceğini öngörmüş olmalıdır, ancak Kyros muhtemelen bu duruma çok kızdığı için hızlı bir şekilde Sardeis'e yürümüş ve kenti yağmalatarak Lydia Krallığı'na son vermiştir.

Sonuç olarak arkeolojik ve tarihsel veriler Kerkenes'in Kimmerlere karşı savaşmak için Lydia Krallığı tarafından kurulmuş en az üç askeri garnizondan birisi olduğunu ve Persler tarafından Lydialılar yenilene kadar bu işlevini sürdürmüş olduğunu göstermektedir. Hellence pteria kelimesi ise, bir kent ismi değil Lydia sınırını betimlemek amacıyla kullanılmış bir ifade olmalidır. 


\section{KAYNAKÇA}

Anderson J. G. C. (1903). Studia Pontica: I, A Journey of Exploration in Pontus. Bruxelles 1903.

Baran A. (2014). "Kerkenes (Sorgun-Yozgat) Kazı Çalışmaları 2012”. KST XXXV (2012) 76-92.

Baran A. (2015). “Kerkenes (Sorgun-Yozgat) Kazı Çalışmaları 2013”. KST XXXVI (2015) 1-22.

Berndt-Ersoz S. (2006). Phrygian Rock-cut Shrines Structure, Function, and Cult Practice Culture and History of the Ancient Near East. Leiden-Boston 2006.

Berndt-Ersoz S. (2009). "Sacred Space in Iron Age Phrygia”. Eds. C. Gates, J. Morin \& T. Zimmerman. Sacred Landscapes in Anatolia and Neighboring Regions (2009) 11-19. Oxford.

Berndt-Ersoz S. (2012). "The Phrygian Kingdom: Origins, History and Political Development”. Ed. T. Tüfekçi-Sivas \& H. Sivas, Frigler: Midas'ın Ülkesinde, Anıtların Gölgesinde/Phrygians in the Land of Midas: In the Shadow of Monument (2012) 16-41. İstanbul.

Bittel K. (1970). Hattusha: The Capital of the Hittites. Oxford 1970.

Bossert E. M. (2000). Die Keramik Phrygischer Zeit von Boğazköy. Funde aus den Grabungskampagnen 1906, 1907, 1911, 1912, 1931-1939, und 1952-1960. Mainz 2000.

Branting S. (2004). Iron Age Pedestrians at Kerkenes Dağ: an Archaeological GIS-T Approach to Movement and Transportation. Unpublished PhD Thesis. State University of New York, Buffalo 2004.

Branting S. (2016). "Kerkenes Dağı 2014" KST XXXVII (2016) 1-12.

Cobbe H. M. T. (1967). “Alyattes’ Median War”. Hermathena 105 (1967) 21-33.

De Boer J. G. (2006). "The Cimmerian Invasions in Anatolia and the Earliest Greek Colonies in the Black Sea Area”. Eirene 42 (2006) 62-74.

Dönmez Ş. (2004). “Akalan Hakkında Yeni Gözlemler”. Anadolu Araştırmaları 17 (2004) 67-91.

Dönmez Ş. (2007). "The Central Black Sea Region, Turkey, During the Iron Age: the Local Cultures and the Eurasian Horse-Riding Nomads”. Ed. D. V. Grammenos \& E. K. Petropoulos, Ancient Greek Colonies in the Black Sea II/2 (2007) 1207-20.

Draycott C. M., Summers G. D. \& Brixhe CL. (2008). Kerkenes Special Studies 1: Sculpture and Inscriptions from the Monumental Entrance to the Palatial Complex at Kerkenes Dag, Turkey. Chicago 2008.

Dusinberre E. R. M. (2002). “An Excavated Ivory from Kerkenes Dağ, Turkey: Transcultural Fluidities, Significations of Collective Identity, and the Problem of Median Art". Ars Orientalis 32 (2002) 17-54.

Ersoy Y. (2007). "Notes on History and Archaeology of Early Clazomenae”. Ed. J. Cobet, V. von Graeve, W.-D. Niemeier \& K. Zimmermann, Milesische Forschungen 5. Frühes Ionien: eine Bestandaufnahme. Akten des Internationalen Kolloquiums zum einhundertjāhrigen Jubilāum der Ausgrabungen in Milet, Panionion/Güzelçamlı (2007) 149-178. Mainz.

French D. (1989). “Sinop: The So-Called Ceneviz Yolu”. Ed. K. Emre, B. Hrouda, M. Mellink \& N. Ozgüç, Anatolia and The Ancient Near East: Studies in Honor of Tahsin Özgüç (1989) 143-147. Ankara.

Glendinning M. R. (1996). “A Mid-Sixth-century Tile Roof System at Gordion”. Hesperia 59/1 (1996) 99119.

Greenewalt C. H. Jr. (1970). “Orientalizing Pottery from Sardis: The Wild Goat Style”. California Studies in Classical Antiquity 3 (1970) 55-89.

Herodotos (1991). Herodot Tarihi. Çev. M. Gökmen. İstanbul 1991.

Herodotus (1920). Histories. Trans. A. D. Godley. Cambridge 1920.

Herodotus (2003). Histories. Trans. J. Marincola. (Anonymus) 2003.

Högemann P. (1999). “Kroisos”. Der Neue Pauly 6 (1999) 858-860.

Huntington E. (1901). "Weitere Berichte über Forschungen in Armenien und Commagene”. Zeitschrift für Ethnologie 33 (1901) 173-209.

Huxley G. (1997). “A Lydo-Median Treaty in Herodotus (1.74.3-4)”. Deltio XII (1997) 9-11.

Hürmüzlü B. (2005). “The Organization and Utilization of the Burial Grounds in Klazomenai”. OLBA XII (2005) 39-67.

Ivantchik A. (2010). "Un choc des civilisations au VIIe siècle av. J.-C. : les invasions des Cimmériens et 
des Scythes au Proche-Orient et les origines de la culture scythe”. Ed. R. Etienne, La Méditerranée au VIIème siècle av. J.-C. (Travaux de la Maison René Ginouvès, 7). (2010) 38-58. Paris.

Johnson P. (2010). Landscapes of Achaemenid Paphlagonia. Publicly Accessible Penn Dissertations. University of Pennsylvania, Pennsylvania 2010.

Kerschner M. (2006). “On the Provenance of Aiolian Pottery”. Ed. A. Villing \& U. Schlotzhauer, Naukratis: Greek Diversity in Egypt. Studies on East Greek Pottery and Exchange in the Eastern Mediterranean (2006) 109-126. London.

Khatchadourian L. (2016). Imperial Matter: Ancient Persia and the Archaeology of Empires. California 2016.

Kuhlmann P. (1994). Die Giessener literarischen Papyri. Giessen 1994

Langis-Barsetti D. (2013). "Results of the 2011 geophysical survey at Kerkenes Dağ, Central Anatolia". Anatolia Antiqua 21 (2013) 69-86.

Liddell H. G. \& Scott R. (1940). A Greek-English Lexicon. Ed. H. S. Jones \& R. McKenzie. Oxford 1940.

Michels C. (2011). “Cyrus’ II campaigns against the Medes and the Lydians”. Ed. R. Rollinger, B. Truschnegg \& R. Bichler, Herodot und das Persische Weltreich. Herodotus and the Persian Empire, Classica et Orientalia 3 (2011) 689-704. Wiesbaden.

Özyiğit Ö. (1994). “The City Walls of Phokaia”. REA 96 (1994) 77-109.

Polyaenus (1793). Polyaenus's Stratagems of War. Trans. R. Shepherd. London 1793.

Przeworski S. (1929). “Die Lage von Pteria”. Archiv Orientalni 1 (1929) 312-315.

Rollinger R. (2003a). “The Western Expansion of the Median 'Empire’: A Re-Examination”. Ed. G. B. Lanfranchi, M. Roaf \& R. Rollinger, Continuity of Empire (?). Assyria, Media, Persia (HANE/M V) (2003) 289-319. Padua.

Rollinger R. (2003b). "Kerkenes Dağ and the Median 'Empire"”. Ed. G. B. Lanfranchi, M. Roaf \& R. Rollinger, Continuity of Empire (?). Assyria, Media, Persia (HANE/MV) (2003) 321-326. Padua.

Rollinger R. (2008). “The Median "Empire”, the End of Urartu and Cyrus' the Great Campaign in 547 BC (Nabonidus Chronicle II 16)”. Ancient West \& East 7 (2008) 49-63.

Rollinger R. (2010). "Das medische Königtum und die medische Suprematie im sechsten Jahrhundert v. Chr.”. Ed. G. Lanfranchi \& R. Rollinger, Concepts of Kingship in Antiquity (HANE/M X) (2010) 63-85.

Rose B. (2012). The Archaeology of Phrygian Gordion, Royal City of Midas, Gordion Special Studies. Pennsylvania 2012.

Schmidt E. F. (1929). “Test Excavations in the City on Kerkenes Dagh”. The American Journal of Semitic Languages and Literatures 45/4 (1929) 221-274.

Summerer L. (2008). “Indigenous Responses to Greek Encounters in Northern Anatolia. Reception of the Architectural Terracottas in the Iron Age Settlements in the Halys-Basin”. Ed. Pia Guldager Bilde, Meetings of Cultures in the Black Sea Region; Between Conflict and Coexistence. Black Sea Studies 8 (2008) 263-286. Aarhus.

Summers M. E. F., Ahmet K. \& Summers G. D. (1995). “The Regional Survey at Kerkenes Dağ: An Interim Report on the Seasons of 1993 and 1994”. Anatolian Studies 45 (1995) 43-68.

Summers G. D., Summers M. E. F., Baturayoğlu N., Harmanşah Ö. \& McIntosh E. R. (1996). “The Kerkenes Dağ Survey: An Interim Report”. Anatolian Studies 46 (1996) 201-234.

Summers G. D. (1997). "The Identification of the Iron Age City on the Kerkenes Dağ in Central Anatolia”. Journal of Near Eastern Studies 56 (1997) 81-94.

Summers G. D. (2000). “The Median Empire Reconsidered: A View from Kerkenes Dağ”. Anatolian Studies 50 (2000) 55-73.

Summers G. D. (2001). "Keykavus Kale and Associated Remains on the Kerkenes Dağ in Cappadocia, Central Turkey”. Anatolia Antiqua 9 (2001) 39-60.

Summers G. D. \& Summers, F. (2003). Kerkenes Projesi, 2003 Yll Araştırma Sezonu Ön Raporu (2003). Kaynak:http://kerkenes.metu.edu.tr/kerk2/01reports/pdf/03reptrdjet.pdf

Summers G. D., Summers F. \& Branting S. (2004). "Megarons and Associated Structures at Kerkenes Dag: an Interim Report”. Anatolia Antiqua 12 (2004) 7-41. 
Summers G. D. (2006a). "Aspects of Material Culture at the Iron Age Capital on the Kerkenes Dağ in Central Anatolia”. Ancient Near Eastern Studies 43 (2006) 163-201.

Summers G. D. (2006b). "Phrygian Expansion to the East: Evidence of Cult from Kerkenes Dağ". Baghdader Mitteilungen 37 (2006) 647-656.

Summers G. D. \& Summers F. (2006c) "Aspects of Urban Design at the Iron Age City on the Kerkenes Dağ as revealed by Geophysical Survey". Anatolia Antiqua 14 (2006) 71-88.

Summers G. D. (2007). "Public Spaces and Large Halls at Kerkenes”. Ed. A. Çilingiroğlu, A. Sagona. Anatolian Iron Ages 6: The Proceedings of the Sixth Anatolian Iron Ages Colloquium Held at Eskişehir, 16-20 August 200011 (2007) 241-259.

Summers G. D., Summers F. (2008) "A Preliminary Interpretation of Remote Sensing and Selective Excavation at the Palatial Complex, Kerkenes”. Anatolia Antiqua 16 (2008) 53-76.

Summers G. D. (2009). "Between Urartu and Phrygia: the North-Central Anatolian Plateau in the Iron Age”. Ed. H. Sağlamtimur, E. Abay, Z. Derin, A.Ü. Erdem, A. Batmaz, F. Dedeoğlu, M. Erdalkıran, M.B. Baştürk \& E. Konakçı, Studies in Honour of Altan Çilingiroğlu: a life dedicated to Urartu on the shores of the Upper Sea, Arkeoloji ve Sanat (2009) 657-671. İstanbul.

Summers G. D., Summers F. (2011). Kerkenes News 14 (2011) Kaynak: http://www.kerkenes. metu.edu.tr/kerk1/12propub/kerknews/2011/Turkce/kn12s0607.html

Summers G. D. \& Summers F. (2012a). "Kerkenes Dağ". Ed. T. Tüfekçi Sivas \& H. Sivas, Frigler: Midas'in Ülkesinde, Anitlarin Gölgesindel Phrygians in the Land of Midas: In the Shadow of Monument, Yapı Kredi Kültür Sanat (2012) 162-183. İstanbul.

Summers G. D., Summers F. (2012b). "Kerkenes: 20 Years of Research and Exploration”. Heritage Turkey, British Institute at Ankara Research Reports 2 (2012) 25-27.

Summers G. D., Branting S., Baltalı Tırpan S., Baturayoğlu Yöney N. \& Lehner J. (2012c) "Kerkenes 2010”. KST XXXIII 2012 535-558.

Summers G. D. \& Summers F. (2013a). "The Kale at Kerkenes Dag: An Iron Age Capital in Central Anatolia”. Ed. S. Redford \& N. Ergin, Cities and Citadels in Turkey: from the Iron Age to the Seljuks (2013) 137-159.

Summers G. D. (2013b). “Connectivity and Cultural Isolation at Kerkenes, an Iron Age Capital in Central Turkey”. Ed. L. Bombardieri, SOMA 2012 Identity and Connectivity: Proceedings of the 16th Symposium on Mediterranean Archaeology 16 (2013) 225-232. Oxford.

Summers G. D. (2014). "East of the Halys: Thoughts on Settlement Patterns and Historical Geography in the Late 2nd Millennium and First Half of the First Millennium B.C.”. Ed. H. Bru \& G. Labarre, L'Anatolie des peuples, des cités et des cultures (IIe millénaire av. J.-C. - Ve siècle ap. J.-C.) Colloque international de Besançon - 26-27 novembre 2010 (2014) 41-51. Besançon.

Texier C. (1839). Description de l'Asie Mineure: faite par ordre du gouvernement français en 1833 - 1837; beaux-arts, monuments historiques, plans et topographie des cités antiques. Band 1. Paris 1839.

Tuplin C. (2004). "Medes in Media, Mesopotamia, and Anatolia Empire, Hegemony, Domination or Illusion”. Ancient West \& East 3/2 (2004) 223-251.

Vergnaud B. (2012). Recherches sur les fortifications d'Anatolie occidentale et centrale au début du premier millénaire av. J.-C. (Xe-VIe s.). Unpublished PhD Thesis. Université Michel de Montaigne, Bordeaux 2012.

Vergnaud B. (2013). “A Phrygian Identity in Fortifications?”. Ed. L. Bombardieri, SOMA 2012 Identity and Connectivity: Proceedings of the 16th Symposium on Mediterranean Archaeology, Florence, Italy, 1-3 March 2012. (2013) 233-241. Oxford.

Van De Mieroop M. (2011). A History of the Ancient Near East ca. 3000-323 BC. Wiley 2011.

von der Osten H. H. (1928). “An Unnoticed Ancient Metropolis of Asia Minor”. Geographical Review 28 (1928) 83-92.

Wittke A. M. (2014). “Überlegungen Zur Lage Von Pteria”. Ed. S. Gaspa, A. Greco, D. M. Bonacossi, S. Ponchia \& R. Rollinger, From Source to History Studies on Ancient Near Eastern Worlds and Beyond Dedicated to Giovanni Battista Lanfranchi on the Occasion of His 65th Birthday on June 23, 2014. (2014) 745-765. Münster. 